\title{
Nocturnal asthma is affected by genetic interactions between RORA and NPSR1
}

DOI:

10.1002/ppul.24292

Document Version

Accepted author manuscript

Link to publication record in Manchester Research Explorer

\section{Citation for published version (APA):}

Curtin, J., \& et al (2019). Nocturnal asthma is affected by genetic interactions between RORA and NPSR1.

Pediatric Pulmonology. https://doi.org/10.1002/ppul.24292

\section{Published in:}

Pediatric Pulmonology

\section{Citing this paper}

Please note that where the full-text provided on Manchester Research Explorer is the Author Accepted Manuscript or Proof version this may differ from the final Published version. If citing, it is advised that you check and use the publisher's definitive version.

\section{General rights}

Copyright and moral rights for the publications made accessible in the Research Explorer are retained by the authors and/or other copyright owners and it is a condition of accessing publications that users recognise and abide by the legal requirements associated with these rights.

\section{Takedown policy}

If you believe that this document breaches copyright please refer to the University of Manchester's Takedown Procedures [http://man.ac.uk/04Y6Bo] or contact uml.scholarlycommunications@manchester.ac.uk providing relevant details, so we can investigate your claim.

\section{OPEN ACCESS}


Nocturnal asthma is affected by genetic interactions between RORA and NPSRI

Vincent D. Gaertner B.Sc. ${ }^{1}$, Sven Michel $\mathrm{PhD}^{1}$, John A. Curtin $\mathrm{PhD}^{2}$, Ville Pulkkinen $\mathrm{PhD}^{3}$, Nathalie Acevedo $\mathrm{PhD}^{4,5}$, Cilla Söderhäll $\mathrm{PhD}^{6,7}$, Andrea von Berg $\mathrm{MD}^{8}$, Albrecht Bufe $\mathrm{MD}^{9}$, Otto Laub MD ${ }^{10}$, Ernst Rietschel MD ${ }^{11}$, Andrea Heinzmann MD ${ }^{12}$, Burkhard Simma MD ${ }^{13}$, Christian Vogelberg $\mathrm{MD}^{14}$, Göran Pershagen $\mathrm{PhD}^{15}$, Erik Melén $\mathrm{PhD}^{15,16}$, Angela Simpson $\mathrm{PhD}^{2}$, Adnan Custovic $\mathrm{PhD}^{17}$, Juha Kere $\mathrm{PhD}^{6,18}$, and Michael Kabesch $\mathrm{MD}^{1}$ *

${ }^{1}$ University Children's Hospital Regensburg (KUNO), Department of Pediatric Pneumology and Allergy, Regensburg, Germany

${ }^{2}$ Division of Infection Immunity and Respiratory Medicine, School of Biological Sciences, The University of Manchester, Manchester Academic Health Science Centre, and Manchester University NHS Foundation Trust, Manchester, UK

${ }^{3}$ Heart and Lung Center, Division of Pulmonary Medicine, University of Helsinki and Helsinki University Central Hospital, Helsinki, Finland

${ }^{4}$ Department of Clinical Science and Education, Karolinska Institutet, Sweden

${ }^{5}$ Institute for Immunological Research. University of Cartagena, Cartagena, Colombia

${ }^{6}$ Department of Biosciences and Nutrition, Karolinska Institutet, Huddinge, Sweden

${ }^{7}$ Department of Women's and Children's Health, Karolinska Institutet, Stockholm, Sweden

${ }^{8}$ Research Institute for the Prevention of Allergic Diseases, Children's Department, MarienHospital, Wesel, Germany

${ }^{9}$ Department of Experimental Pneumology, Ruhr-University, Bochum, Germany

${ }^{10}$ Kinder- und Jugendarztpraxis Laub, Rosenheim, Germany

${ }^{11}$ University Children's Hospital, Faculty of Medicine, University of Cologne, Cologne, Germany

${ }^{12}$ Center for Pediatrics, Department of General Pediatrics, Adolescent Medicine and

Neonatology, Medical Center - University of Freiburg, Faculty of Medicine, University of

Freiburg, Germany

${ }^{13}$ Children's Department, University Teaching Hospital, Landeskrankenhaus Feldkirch, Feldkirch, Austria

${ }^{14}$ University Children's Hospital, Technical University Dresden, Dresden, Germany

${ }^{15}$ Institute of Environmental Medicine, Karolinska Institutet and Centre for Occupational and Environmental Medicine, Stockholm County Council, Stockholm, Sweden

${ }^{16}$ Sachs' Children and Youth Hospital, Södersjukhuset, Stockholm, Sweden

${ }^{17}$ Department of Paediatrics, Imperial College, London, UK

${ }^{18}$ Research Programs Unit, Program for Molecular Neurology, University of Helsinki, and Folkhälsän Institute of Genetics, Helsinki, Finland

${ }^{19}$ School of Basic \& Medical Biosciences, King's College London, London, England

*Corresponding author:

Michael Kabesch

Steinmetzstr. 1-3

93047 Regensburg, Germany

Tel: +49-941-3695901

E-mail: michael.kabesch@ukr.de (MK) 
Funding: This work was funded by the German Lung Research Center (DZL), Swedish Research Council, the Distinguished Professor Award at Karolinska Institutet to JK, and the Sigrid Jusélius Foundation. BAMSE was supported by the Swedish Research Council, the Swedish Heart-Lung Foundation and the Swedish Research Council Formas. MAAS was supported by Asthma UK Grants No 301 (1995-1998), No 362 (1998-2001), No 01/012 (2001-2004), No 04/014 (2004-2007), BMA James Trust (2005) and The JP Moulton Charitable Foundation (2004-current), The North west Lung Centre Charity (1997-current) and the Medical Research Council (MRC) G0601361 (2007-2012), MR/K002449/1 (20132014) and MR/L012693/1 (2014-2018). The funding sources had no role in the study design; the collection, analysis and interpretation of data; the writing of the report; and in the decision to submit the article for publication.

Conflicts of interest: AC received personal fees from Novartis, Regeneron/Sanofi, ALK, ThermoFisher, Boehringer Ingelheim, Novartis, Philips, all outside the submitted work. AS reports grants from Medical Research Council and from the National Institute of Health Research during the conduct of the study. MK received personal fees for lectures from ERS, EAACI, ATS, Novartis, Glaxo, Nutricia, and Hipp as well as research grants from the European Union, the German Ministry of Education and Research, and the German Research Foundation. VDG received travel fees for lectures from the European Academy of Allergy and Clinical Immunology (EAACI). All other authors report no conflict of interest.

Short title: RORA and NPSR1 affect nocturnal asthma

Keywords: nighttime asthma, childhood asthma, genetic epistasis, circadian rhythm 
74

\section{Abstract}

Background: Neuropeptide S Receptor 1 (NPSR1) and Retinoid Acid Receptor-Related Orphan Receptor Alpha (RORA) interact biologically, are both known candidate genes for asthma and are involved in controlling circadian rhythm. Thus, we assessed (1) whether interactions between RORA and NPSRI specifically affect the nocturnal asthma phenotype and (2) how this may differ from other asthma phenotypes.

Methods: Interaction effects between 24 SNPs in RORA and 35 SNPs in NPSR 1 on asthma and nocturnal asthma symptoms were determined in 1,432 subjects [763 asthmatics (192 with nocturnal asthma symptoms); 669 controls] from the MAGICS/ISAAC studies. The results were validated and extended in children from MAAS $(\mathrm{N}=723)$ and the BAMSE cohort $(\mathrm{N}=1,646)$.

Results: RORA*NPSR1 interactions seemed to affect both asthma and nocturnal asthma. In stratified analyses, however, interactions mainly affected nocturnal asthma and less so asthma without nocturnal symptoms or asthma severity. Results were replicated in two independent cohorts and seemed to remain constant over time throughout youth.

Conclusion: $R O R A^{*} N P S R 1$ interactions appear to be involved in mechanisms specific for nocturnal asthma. In contrast to previous studies focusing on the role of beta 2 receptor polymorphisms in nocturnal asthma as a feature of asthma control or severity in general, our data suggests that changes in circadian rhythm control are associated with night-time asthma symptoms.

Word count Abstract: 210/250

Word count main text: $3494 / 3500$ 


\section{Abbreviations}

BAMSE

100

101

102

103

104

105

106

107

108

109

110 MAGIC

111 NPS

112 NPSRI

113 OR

114 P300

$115 \mathrm{QC}$

116 RORA

117 Rs

118 SNP

119 STAT3
Children Allergy Milieu Stockholm an Epidemiological study

Confidence Interval

DPY19 like C-mannosyltransferase 1

GATA binding protein 3

Genome-wide association study

Hardy-Weinberg Equilibrium

Interleukin 4 gene

Interleukin 5 gene

Interleukin 13 gene

International Study of Asthma and Allergies in Childhood phase II

Linkage Disequilibrium

Multicenter Asthma Genetic in Childhood

Neuropeptide S

Neuropeptide S Receptor 1 gene

Odds Ratio

Histone acetyltransferase p300

Quality control

Retinoic acid receptor-related Orphan Receptor Alpha gene

Reference SNP cluster code (dbSNP)

Single Nucleotide Polymorphism

Signal transducer and activator of transcription 3 


\section{INTRODUCTION}

Nocturnal asthma is defined as night-time occurrence of asthmatic symptoms such as wheezing, coughing, or chest tightness 1,2 . Between 30 and $75 \%$ of asthma patients experience these symptoms ${ }^{3-5}$. It is known that the circadian rhythm controls airway inflammation, vagal activity, and epinephrine release ${ }^{6}$, thus potentially aggravating asthma symptoms during the night ${ }^{6,7}$. Nocturnal asthma may either be a feature related to asthma severity or alternatively, it may be a subphenotype of the disease, associated with the presence of specific and unique molecular patterns ${ }^{8}$. This goes along with the current understanding that asthma is not a homogenous and uniform disease but rather, a syndrome to which different mechanisms may contribute in individuals and specific group of patients.

Interestingly, two candidate genes for asthma, NPSR1 (chromosome 7p14.3) and RORA (chromosome 15q22.2), have recently been suggested to play a role in controlling circadian rhythm ${ }^{9-11}$. NPSR 1, a G protein-coupled receptor, has been associated to asthma susceptibility in numerous studies ${ }^{12-14}$, while also having been related to the circadian rhythm in mice and humans ${ }^{9,15}$. RORA, a nuclear hormone receptor, was associated with asthma ${ }^{16,17}$ and its mRNA expression varies during human lung development and during murine lung inflammation ${ }^{11,18-}$ ${ }^{20}$. Also, RORA is known to influence the circadian rhythm of various physiological processes 11,18-22. Finally, it was recently suggested that RORA and NPSR 1 interact biologically by influencing promoter activity and each other's gene expression thereby modifying asthma risk concomitantly 23

We hypothesized that through their effects on circadian rhythm and asthma, RORA and NPSRI would specifically influence nocturnal asthma. Thus, the aims of this study were (1) to 
144 investigate whether gene-gene-interactions between RORA and NPSR1 specifically affect the 145 occurrence of nocturnal asthma and (2) to differentiate these effects from asthma without 146 nocturnal symptoms or severe asthma. 


\section{MATERIALS AND METHODS}

\section{Study populations}

As a discovery population in a case reference design we investigated participants from the Multicenter Asthma Genetic in Childhood study (MAGICS) and the cross-sectional International Study of Asthma and Allergies in Childhood phase II (ISAAC II) as previously described in the first GWAS on asthma $(\mathrm{N}=1,454){ }^{24}$. Replication was carried out in two population-based birth cohorts: BAMSE (Children Allergy Milieu Stockholm Epidemiology study; N=2,033) from Sweden and MAAS (Manchester Asthma and Allergy Study; N=1085) from the UK. Study populations have been described elsewhere ${ }^{24-27}$. The studies were approved by the respective ethics committees. Written informed consent was obtained from all parents.

\section{Phenotypes}

In MAGICS, asthma was diagnosed by a pediatric pulmonologist based on clinical presentation and objective measures including lung function and allergy tests. In ISAAC II and BAMSE, a parentally reported physician's diagnosis had to be present while in MAAS children with at least two out of three features [(1) Wheezing or whistling in the chest in the last 12 months; (2) Current use of asthma medication; (3) Physician-diagnosed asthma ever] were compared to children with $0 / 3$ features.

Nocturnal asthma was defined as asthma plus parentally reported wheezing or gasping during the night at least once over the previous 12 months in MAGICS/ISAAC and MAAS. In BAMSE, asthma plus any coughing or breathing difficulties throughout the night sufficed. Due to this 
slight disparity, phenotypes were denominated differently: nocturnal asthma symptoms (MAGICS/ISAAC and MAAS) and nocturnal breathing difficulties (BAMSE). In MAAS, phenotypes were also assessed at 16 years. Figure 1 displays the number of patients in each group. Subjects with neither asthma nor nocturnal symptoms served as controls in all cohorts.

Asthma severity is not unanimously defined and it was thus assessed differently in all cohorts: in MAGICS/ISAAC, the number of hospital, emergency department or doctor visits due to asthmatic symptoms was counted; in MAAS, the number of exacerbations over twelve months were counted; and in BAMSE, nighttime wheezing, the use of asthma medication and activity limitation were assessed. Asthma severity was assessed as a continuous variable within the asthmatic cases only.

\section{Functional database scan}

Functional databases (HaploReg, SNPinfo, SNiPA, ENCODE, Roadmap Epigenomics project, GRASP database) were systematically screened for functional relevance of associated SNPs. Sequence conservation analyses were based on SiPhy and GERP elements. Regulatory protein binding was obtained from the ENCODE ChIP-Seq data, epigenomic data from the Roadmap Epigenomics project and eQTL from GTEx and the GRASP database.

For study design, SNP selection and genotyping details please refer to the online supplement.

\section{Statistical analysis}

Associations of binary traits were evaluated by logistic regression, interactions were assessed using the --epistasis command and deviation from Hardy-Weinberg equilibrium was analyzed by chi-square test in the control group, all using PLINK 1.0.7 ${ }^{28}$. All further analyses were 
performed with R software (3.0.1; http://www.r-project.org/). All markers were in HWE ( $p>0.0001$ ). Odds ratios (OR) and 95\% confidence intervals (CI) are reported for dichotomous variables and beta-values and standard errors (SE) for continuous variables. We present ORs and beta-values instead of providing figures for every single interaction for a better readability and clarity of the text. Linkage Disequilibrium (LD) plots were generated with Haploview ${ }^{29}$.

Testing a specific hypothesis, $p$-values $<0.05$ were considered statistically significant for the replication analyses. In order to account for multiple testing in de novo interaction analyses and to minimize the risk of reporting false positive results, we only discuss polymorphisms for which the number of significant interactions exceeded stochastic expectation, as suggested previously ${ }^{30}$. More precisely, polymorphisms had to display at least three significant interactions with SNPs from the respective other gene (24 SNPs*0.05=1.2 and 35 SNPs* $0.05=1.75 \approx 2$ expected false positive results per SNP). 


\section{RESULTS}

\section{Interactions between RORA and NPSR1 SNPs affect the risk for asthma}

First, we investigated systematically if gene-gene-interactions between RORA and NPSRI affect asthma in our MAGICS/ISAAC population. For that we enriched the two gene loci with all SNPs previously associated with asthma, confirming and expanding a previous report by Acevedo, where a smaller number of SNPs were studied in the BAMSE and PARSIFAL cohorts 23. Indeed, seven SNPs within RORA and eight NPSRI-SNPs were found to significantly contribute to interactions associated with asthma in MAGICS/ISAAC (Figure 2 and Supplementary Table S2). RORA rs12591848 interacted with eight SNPs in NPSR1 [most strongly with rs $\left.1419779 ; \mathrm{OR}(\mathrm{CI})=0.45(0.30-0.68) ; p=1.51^{*} 10^{-4}\right]$ and NPSR1 rs963218 interacted with nine SNPs in $R O R A$ [most strongly with rs12591848; OR(CI) $=0.51(0.35-0.74)$; $\left.p=4.60^{*} 10^{-4}\right]$. Of these newly found interactions, we could replicate five interactions in our additional cohorts (including BAMSE where they were not originally reported) and six of the newly found interactions showed a trend towards significance in the replication cohorts. Especially the combination of rs 2899662 and rs 887020 affected asthma constantly across populations (Table 1 and Supplementary Table S3). Of note, only two combinations of SNPs in each gene were linked with an $\mathrm{r}^{2}>0.80$ (see Supplementary Figures S3 and S4).

\section{Interactions between RORA and NPSR1 SNPs affect nocturnal asthma}

\section{symptoms specifically}

We then assessed epistasis effects on nocturnal asthma in our discovery population. Overall, twelve RORA-SNPs showed at least three significant interactions with SNPs in NPSR1 in relation to nocturnal asthma. Six of these SNPs were only associated with nocturnal asthma, 
and not with asthma per se. Within NPSR1, twelve SNPs showed at least three significant interactions with $R O R A$ when nocturnal asthma symptoms were the outcome. Seven of these SNPs seemed to represent genuine associations with nocturnal asthma, as they did not interact with RORA-SNPs to affect asthma per se. The strongest overall signals were noted for rs6972158 in NPSR1 and rs7171681 in RORA, which each interacted significantly with at least ten SNPs from the respective other gene. The strongest single interaction affecting nocturnal asthma symptoms was found for NPSR1 rs324396 and RORA rs7171681 [OR(CI) $=0.45(0.28$ 0.73); $\mathrm{p}=0.0013$ ] (see Figure 3 and Supplementary Table S5). Taken together, we concluded that indeed numerous gene by gene interactions between RORA and NPSR 1 exist and that these may affect nocturnal asthma.

Now we attempted to replicate the significant results with similar phenotypes in BAMSE and MAAS. Interestingly, we were able to replicate seven interactions in MAAS with six further interactions reaching borderline significance in one of the datasets. Of note, the effect direction was the same in the other replication dataset in most cases (Table 2 and Supplementary Table S6). Particularly the combination of rs $324396 *$ rs 2899662 and $r s 13799228 *$ rs4775292 affected nocturnal asthma strongly in all cohorts. To detect temporal continuity we assessed whether interaction effects at age 11 remained associated with nocturnal asthma at age 16 in MAAS. Intriguingly, two out of eleven interactions still affected nocturnal asthma significantly at age $16(\mathrm{rs} 324396 *$ rs 2899662 and $\mathrm{rs} 324396 *$ rs 341382) and four interactions reached borderline significance (Supplementary Table S7).

Finally, we rigorously prioritized associated SNPs based on the number of original interactions (interacting with $\geq 25 \%$ of the other gene's SNPs) and the number of replicated interactions ( $\geq 2$ 
replications) to only include our main hits $(\mathrm{N}=10$, see Supplementary Figure S5). Scanning various databases, we found that all but two of our top SNPs are predicted to have relevant functional impact (Table 3): While one SNP (rs6972158) results in a non-conservative amino acid change from glutamine to arginine in NPSR1, seven out of the remaining nine SNPs are tightly linked to SNPs predicted to be located in promoter regions and five SNPs alter transcription factor binding sites for various proteins known to play important roles in immunology and chronobiology ${ }^{31,32}$. In turn, 6 of these SNPs also lead to a differential gene expression in tested tissues. Of note, 3 of these SNPs are located in phylogenetically highly conserved regions.

\section{RORA and NPSR1 interactions have minor effects on asthma without}

\section{nocturnal symptoms}

Next, we analysed if RORA by NPSR 1 interactions affect asthmatics without nocturnal asthma symptoms. If RORA by NPSRl interactions were involved in a mechanism specific for nocturnal asthma, associations in asthmatics without nocturnal symptoms would be expected to be absent or much weaker than the ones found in asthmatics with nocturnal symptoms. Indeed, there were fewer interactions associated with the occurrence of asthma without nocturnal symptoms: only four NPSR I-SNPs interacted with $\geq 3 R O R A$-SNPs and only two RORA-SNPs interacted with $\geq 3$ SNPs in NPSR1. The strongest interaction was noted for NPSR1 rs323917* $R O R A$ rs $17204454[\mathrm{OR}(\mathrm{CI})=0.29(0.13-0.61) ; p=0.0012]$. We could replicate one interaction in BAMSE and most interactions had the same effect direction (Supplementary Tables S8 and S9). In comparison, as seen above, there was a total of 24 SNPs from both genes interacting with $\geq 3$ SNPs from the respective other gene when asthma with nocturnal symptoms was the 
outcome. Results of these analyses are displayed in a comparative manner in Figure 3. Of note, atopy status in asthmatics $(71.8 \%)$ and nocturnal asthmatics $(74.0 \%)$ was comparable.

\section{Effects of RORA and NPSR 1 interactions on asthma severity}

To further disentangle whether RORA and NPSR 1 specifically affect nocturnal asthma we also sought to describe the two genes' effects on asthma severity in our three populations, even though one has to be aware that severity definitions varied somewhat between these studies (as described in the methods section). This analysis was based on the assumption that the effects on nocturnal asthma may be influenced and/or partly explained by asthma severity. We could show that seven $R O R A$-SNPs as well as nine NPSR 1 -SNPs interacted with $\geq 3$ SNPs from the respective other gene to associate with asthma severity (Supplementary Figure S2). Overall, there were 52 significant interactions [strongest interaction rs2530547* rs4775289: $B(\mathrm{SE})=0.53(0.14), \mathrm{p}=0.0002]$. Some of these interactions had also affected nocturnal asthma, thus implying that their effect on nocturnal asthma and on asthma severity may be confounded. However, most interactions between RORA and NPSR 1 remained specific for nocturnal asthma. Lastly, four SNPs in RORA as well as three NPSR I-SNPs seemed to be only associated with asthma severity and not nocturnal asthma. However, when trying to replicate our results in the two independent cohorts, we found that almost no interaction had the same effect direction in both replication cohorts for severity, very much in contrast to our constant replications for nocturnal asthma across different cohorts (Supplementary Table S11). 


\section{DISCUSSION}

This study deciphers a plausible genetic mechanism for nocturnal asthma by demonstrating that interactions between RORA and NPSRI are specifically associated with nocturnal asthma, suggesting the involvement of a genetic mechanism related to circadian rhythm control.

We replicated and extended recent observations that interactions between RORA and NPSRI increase the risk to develop asthma in three independent cohorts. By systematically enriching both RORA and NPSRl gene loci we identified a number of additional and novel gene-geneinteractions driving asthma. The most intriguing and novel result from our study, however, is that interactions between RORA and NPSRI strongly associate with nocturnal asthma, rather than asthma per se. There has been limited evidence for a genetic background of nocturnal asthma, all relating to the beta2 adrenoreceptor (ADRB2), coming from rather small datasets 33-35. These studies followed the hypothesis that mutations in ADRB2 increase airway constriction in asthmatics and reduce the response to treatment, thus increasing symptoms and severity, possibly even pronounced at night. Our study now shows a mechanism specific for nocturnal symptoms by deciphering molecular associations within genes of the circadian rhythm: As both genes under investigation have been independently associated with asthma susceptibility ${ }^{12-14,16,23}$ and seem to play a role in defining the circadian rhythm ${ }^{15,18}$, the observed associations are biologically plausible.

There are some limitations to our study: Firstly, it has to be acknowledged that this was a retrospective study design with questionnaire-based definitions of nocturnal symptoms as well as asthma severity. This may have led to an under-estimation of the number of nocturnal asthmatics, possibly indicated by the low number of nocturnal asthmatics in our study. This 
may potentially have skewed the results. However, a failure to assign some of the nocturnal asthmatics to any respective group would normally lead to an under-estimation of the power of any found difference, thereby potentially even under-estimating the actual effect size. Secondly, we tested a number of independent associations, thus raising the issue of multiple testing. We tried to avoid false-positive results by focusing on polymorphisms for which the number of significant interactions exceeded the stochastic expectation ${ }^{30}$. Considering only SNPs that showed $\geq 3$ interactions reduced (but did not exclude) the probability of obtaining false-positive results. For interaction analyses it is biologically plausible that SNPs would interact with several SNPs from the respective other gene if they have impact on function ${ }^{23}$.

Intriguingly, we were able to replicate several interactions in MAAS even though replication of interaction analyses is only rarely achieved ${ }^{36}$. Replication analyses with the phenotype nocturnal breathing difficulties in BAMSE did not reach significance. This may partly be due to the difference in phenotypes: In MAGICS/ISAAC and MAAS, the phenotype was relatively specific for asthma as it asked for nocturnal wheezing or gasping. In BAMSE, however, parents were asked for general coughing and breathing difficulties at night which is less specific for asthma. This could also explain why in BAMSE 307 children showed nocturnal breathing difficulties without having asthma, while only 14 children in MAGICS/ISAAC and no child in MAAS reported nocturnal symptoms without an asthma diagnosis. However, even in BAMSE, effect directions were the same for almost all interactions. The constant replication and the extension to nocturnal asthma at age 16 in MAAS implies (1) that this is a mechanism specific for nocturnal asthma and (2) that this mechanism is stable over populations and over time. The stability of these findings is intriguing, as replication of interaction effects is difficult to achieve 36. To find and replicate interactions despite our relatively small sample sizes of approximately 
1,000-1,500 individuals in each dataset implies a strong effect size of these interactions, indeed indicated by relatively high odds ratios. A further strength of our study is the clinically defined asthma phenotype that was largely obtained by a pediatric pulmonologist rather than by parental report.

To assess whether these results are explained by the similarity between nocturnal asthma and severe asthma we compared RORA by NPSRl effects on asthma severity with our findings on nocturnal asthma. However, it has to be noted that this analysis was performed to differentiate nocturnal asthma from severe asthma and should only be interpreted in relation to nocturnal asthma results. We found that the two genes also interact in affecting asthma severity in MAGICS/ISAAC but could not replicate these results in MAAS or BAMSE. The inability to replicate results on this phenotype may be due to different definitions of asthma severity in the three datasets, reflecting the ambiguity of this phenotype. There are several clinical features that contribute to asthma severity, thus making it difficult to comprehensively investigate this phenotype. As nighttime awakenings are sometimes regarded as a feature of asthma severity, it is not yet understood to what extent nocturnal asthma is an independent phenotype. Thus, we sought to discriminate the effect of RORA and NPSR1 on nocturnal asthma and on asthma severity. Based on our data it seems as if nocturnal asthma and asthma severity are related but distinct features of asthma. However, we cannot draw final conclusions due to our failed replications and the ambiguous phenotypes.

The NPS/NPSR1 system as well as RORA have been shown to play a role in circadian rhythm: NPSR knockout mice exhibited lower activity levels under light-dark conditions, NPS injections lead to an increased wakefulness and non-synonymous NPSR1 rs324981 was 
recently associated with a delay of bedtime and sleep duration ${ }^{9,10,15}$. RORA gene expression varies throughout the day and Rora-deficient mice showed a decreased activity and could not adjust to light-dark cycles ${ }^{18,21,23}$. Additionally, RORA modulates the rhythmic expression of downstream target genes, which were recently implicated in mast cell cytokine secretion ${ }^{37}$ and lung epithelial chemokine production ${ }^{38}$, thereby connecting circadian rhythm genes with immunological processes ${ }^{11,18-22}$. Interestingly, NPSRI-overexpressing cells demonstrated an increased mRNA expression of RORA and other circadian genes ${ }^{23,39}$ and in vivo Npsr1deficient mice showed a lower RORA mRNA expression ${ }^{23}$. Reversely, it was shown that RORA regulates NPSR 1 promoter activity ${ }^{23}$. Taken together, both RORA and NPS/NPSR1 signalling appear to be interwoven when acting upon complex immune-related circadian outcomes, and in our case nocturnal asthma.

By systematically scanning online databases for functional relevance of our main hits we found that 8 out of 10 (or their proxy-SNPs in high LD) are predicted to have functional effects: rs6972158 is a missense SNP resulting in an amino-acid change from glutamine to arginine at position 344 of the isoform A of NPSR1. Gln344 is located within the cytosolic domain of the NPSR1 protein and hence, it could have an effect on intracellular signaling. Future in vitro studies should address whether allele specific effects of rs6972158 influence transcription rates of genes involved in the inflammatory response or the molecular clock in lung tissue.

Interestingly, seven out of the remaining nine SNPs are tightly linked to SNPs predicted to be located in promoter regions ${ }^{40}$, and known to be binding sites for protein playing an important role in immunology and chronobiology: GATA3 induces IL-4, IL-5 and IL-13 secretion and is strongly involved in asthma susceptibility ${ }^{32,41}$ and P300 is an important part of the circadian 
clock $^{42}$. Most interestingly, four of our investigated top hits were in tight relation to STAT3 gene expression or showed differential binding capabilities for this relevant transcription factor: Up-regulation of STAT3 is associated with lung inflammation as well as an altered cytokine profile in asthmatic patients ${ }^{31}$. Additionally, it is known to dynamically control Th2 and Th17 cell responses during allergic lung inflammation in mice and humans 31 while being rhythmically expressed and triggered by the endogenous clock ${ }^{43}$. Furthermore, NPSR1 rs1379928, rs1419779 and rs6972158 as well as RORA rs2899662, rs4775301 and rs341382 have been shown to increase downstream gene expression while RORA rs2899662 and rs7171681 are linked to mono- or tri-methylated histone mark H3K4 in T-helper cells, thus promoting downstream gene expression ${ }^{40}$. Therefore, new starting points for functional genomic assessments have been identified.

All in all, major SNPs showing association in interaction analyses in this study seem to be highly relevant for lung inflammation and asthma susceptibility while at the same time being involved in the circadian rhythm by promoting gene expression differentially. However, to conclusively determine biological plausibility of the results, further prospective and mechanistic studies are needed. Thus, it might be worthwhile to study the influence of further circadian rhythm genes on nocturnal asthma, potentially also investigating mitigation by the sympathetic nervous system. Understanding the pathogenesis of nocturnal asthma could increase our clinical and causal knowledge of the disease, thus potentially impacting on improvements in management and care for the affected patients.

Taking all aspects into account, we conclude that RORA and NPSRl interactions are consistent and that these interactions are mainly associated with the development of nocturnal asthma, an 
association which is not only statistically significant but biologically plausible due to the role of both genes in asthma and circadian rhythm. Our data implies that nocturnal asthma is no simple disease entity in the severity spectrum of the disease. Specific molecular patterns regulating the circadian clock, such as those studied here, are associated with nighttime symptoms. Further research could help to clarify mechanisms and introduce potential avenues of intervention in this subphenotype of asthma that is not well understood but highly troublesome for patients.

\section{ACKNOWLEDGEMENTS}

We thank all participants of the MAGIC, ISAAC II, MAAS, BAMSE, and PARSIFAL studies. We thank the Mutation Analysis Core Facility (MAF) at the Karolinska University Hospital for their support with this work. 


\section{REFERENCES}

1. Sutherland ER. Nocturnal asthma. The Journal of allergy and clinical immunology. 2005;116(6):1179-86. doi:10.1016/j.jaci.2005.09.028

2. Ginsberg D. An unidentified monster in the bed - assessing nocturnal asthma in children. McGill journal of medicine : MJM : an international forum for the advancement of medical sciences by students. 2009;12(1):31-8.

3. Meijer GG, Postma DS, Wempe JB, Gerritsen J, Knol K, van Aalderen WM. Frequency of nocturnal symptoms in asthmatic children attending a hospital out-patient clinic. The European respiratory journal. 1995;8(12):2076-80.

4. Raherison C, Abouelfath A, Le Gros V, Taytard A, Molimard M. Underdiagnosis of nocturnal symptoms in asthma in general practice. The Journal of asthma: official journal of the Association for the Care of Asthma. 2006;43(3):199-202.

doi:10.1080/02770900600566744

5. Chugh IM, Khanna P, Shah A. Nocturnal symptoms and sleep disturbances in clinically stable asthmatic children. Asian Pacific journal of allergy and immunology. 2006;24(23):135-42.

6. Burioka N, Fukuoka Y, Koyanagi S, Miyata M, Takata M, Chikumi H, Takane H, Watanabe M, Endo M, Sako T, et al. Asthma: Chronopharmacotherapy and the molecular clock. Advanced Drug Delivery Reviews. 2010;62(9-10):946-955. doi:10.1016/j.addr.2010.03.012

7. Kraft M, Martin RJ, Wilson S, Djukanovic R, Holgate ST. Lymphocyte and eosinophil influx into alveolar tissue in nocturnal asthma. American journal of respiratory and critical care medicine. 1999;159(1):228-34. doi:10.1164/ajrccm.159.1.9804033 
8. Calhoun WJ. Nocturnal asthma. Chest. 2003;123(3 Suppl):399S-405S.

9. Duangdao DM, Clark SD, Okamura N, Reinscheid RK. Behavioral phenotyping of

Neuropeptide S receptor knockout mice. Behavioural Brain Research. 2009;205(1):1-9. doi:10.1016/j.bbr.2009.07.024

10. Zhao P, Shao YF, Zhang M, Fan K, Kong XP, Wang R, Hou YP. Neuropeptide S promotes wakefulness through activation of the posterior hypothalamic histaminergic and orexinergic neurons. Neuroscience. 2012;207:218-226.

doi:10.1016/j.neuroscience.2012.01.022

11. Jetten AM. Retinoid-related orphan receptors (RORs): critical roles in development, immunity, circadian rhythm, and cellular metabolism. Nuclear Receptor Signaling. 2007;4. doi:10.1621/nrs.07003

12. Laitinen T, Polvi A, Rydman P, Vendelin J, Pulkkinen V, Salmikangas P, Mäkelä S, Rehn M, Pirskanen A, Rautanen A, et al. Characterization of a common susceptibility locus for asthma-related traits. Science (New York, N.Y.). 2004;304(5668):300-4. doi:10.1126/science. 1090010

13. Melén E, Bruce S, Doekes G, Kabesch M, Laitinen T, Lauener R, Lindgren CM, Riedler J, Scheynius A, van Hage-Hamsten M, et al. Haplotypes of G Protein-coupled Receptor 154 Are Associated with Childhood Allergy and Asthma. American Journal of Respiratory and Critical Care Medicine. 2005;171(10):1089-1095. doi:10.1164/rccm.200410-1317OC 14. Kormann MSD, Carr D, Klopp N, Illig T, Leupold W, Fritzsch C, Weiland SK, von Mutius E, Kabesch M. G-Protein-coupled receptor polymorphisms are associated with asthma in a large German population. American journal of respiratory and critical care medicine. 2005;171(12):1358-62. doi:10.1164/rccm.200410-1312OC 15. Spada J, Sander C, Burkhardt R, Häntzsch M, Mergl R, Scholz M, Hegerl U, Hensch T. 
Genetic association of objective sleep phenotypes with a functional polymorphism in the neuropeptide S receptor gene. PloS one. 2014;9(6):e98789.

doi:10.1371/journal.pone.0098789

16. Moffatt MF, Gut IG, Demenais F, Strachan DP, Bouzigon E, Heath S, von Mutius E, Farrall M, Lathrop M, Cookson WOCM, et al. A large-scale, consortium-based genomewide association study of asthma. The New England journal of medicine. 2010;363(13):1211-21. doi:10.1056/NEJMoa0906312

17. Torgerson DG, Ampleford EJ, Chiu GY, Gauderman WJ, Gignoux CR, Graves PE, Himes BE, Levin AM, Mathias RA, Hancock DB, et al. Meta-analysis of genome-wide association studies of asthma in ethnically diverse North American populations. Nature genetics. 2011;43(9):887-92.

18. Sato TK, Panda S, Miraglia LJ, Reyes TM, Rudic RD, McNamara P, Naik KA, FitzGerald GA, Kay SA, Hogenesch JB. A functional genomics strategy reveals Rora as a component of the mammalian circadian clock. Neuron. 2004;43(4):527-37. doi:10.1016/j.neuron.2004.07.018

19. Kang HS, Angers M, Beak JY, Wu X, Gimble JM, Wada T, Xie W, Collins JB, Grissom SF, Jetten AM. Gene expression profiling reveals a regulatory role for ROR alpha and ROR gamma in phase I and phase II metabolism. Physiological genomics. 2007;31(2):281-94. doi:10.1152/physiolgenomics.00098.2007 20. Melén E, Kho AT, Sharma S, Gaedigk R, Leeder JS, Mariani TJ, Carey VJ, Weiss ST, Tantisira KG. Expression analysis of asthma candidate genes during human and murine lung development. Respiratory research. 2011;12:86. doi:10.1186/1465-9921-12-86

21. Akashi M, Takumi T. The orphan nuclear receptor RORalpha regulates circadian transcription of the mammalian core-clock Bmal1. Nature structural \& molecular biology. 
2005;12(5):441-8. doi:10.1038/nsmb925

22. Guillaumond F, Dardente H, Giguère V, Cermakian N. Differential control of Bmal1 circadian transcription by REV-ERB and ROR nuclear receptors. Journal of biological rhythms. 2005;20(5):391-403. doi:10.1177/0748730405277232

23. Acevedo N, Sääf A, Söderhäll C, Melén E, Mandelin J, Pietras CO, Ezer S, Karisola P, Vendelin J, Gennäs GB af, et al. Interaction between retinoid acid receptor-related orphan receptor alpha (RORA) and neuropeptide S receptor 1 (NPSR1) in asthma. PloS one. 2013;8(4):e60111. doi:10.1371/journal.pone.0060111

24. Moffatt MF, Kabesch M, Liang L, Dixon AL, Strachan D, Heath S, Depner M, von Berg A, Bufe A, Rietschel E, et al. Genetic variants regulating ORMDL3 expression contribute to the risk of childhood asthma. Nature. 2007;448(7152):470-3. doi:10.1038/nature06014 25. Kull I, Melen E, Alm J, Hallberg J, Svartengren M, van Hage M, Pershagen G, Wickman M, Bergström A. Breast-feeding in relation to asthma, lung function, and sensitization in young schoolchildren. The Journal of allergy and clinical immunology. 2010;125(5):1013-9. doi:10.1016/j.jaci.2010.01.051

26. Custovic A, Simpson BM, Murray CS, Lowe L, Woodcock A, NAC Manchester Asthma and Allergy Study Group. The National Asthma Campaign Manchester Asthma and Allergy Study. Pediatric allergy and immunology: official publication of the European Society of Pediatric Allergy and Immunology. 2002;13 Suppl 15:32-7.

27. Michel S, Liang L, Depner M, Klopp N, Ruether A, Kumar A, Schedel M, Vogelberg C, von Mutius E, von Berg A, et al. Unifying candidate gene and GWAS Approaches in Asthma. PloS one. 2010;5(11):e13894. doi:10.1371/journal.pone.0013894

28. Purcell S, Neale B, Todd-Brown K, Thomas L, Ferreira MAR, Bender D, Maller J, Sklar P, de Bakker PIW, Daly MJ, et al. PLINK: a tool set for whole-genome association and 
population-based linkage analyses. American journal of human genetics. 2007;81(3):559-75. doi:10.1086/519795

29. Barrett JC, Fry B, Maller J, Daly MJ. Haploview: analysis and visualization of LD and haplotype maps. Bioinformatics. 2005;21(2):263-265. doi:10.1093/bioinformatics/bth457 30. Esparza-Gordillo J, Weidinger S, Fölster-Holst R, Bauerfeind A, Ruschendorf F, Patone G, Rohde K, Marenholz I, Schulz F, Kerscher T, et al. A common variant on chromosome $11 \mathrm{q} 13$ is associated with atopic dermatitis. Nature Genetics. 2009;41(5):596-601. doi:10.1038/ng.347

31. Levy DE, Lee C. What does Stat3 do? The Journal of clinical investigation. 2002;109(9):1143-8. doi:10.1172/JCI15650

32. Krug N, Hohlfeld JM, Kirsten A-M, Kornmann O, Beeh KM, Kappeler D, Korn S, Ignatenko S, Timmer W, Rogon C, et al. Allergen-Induced Asthmatic Responses Modified by a GATA3-Specific DNAzyme. New England Journal of Medicine. 2015;372(21):1987-1995. doi:10.1056/NEJMoa1411776

33. Turki J, Pak J, Green SA, Martin RJ, Liggett SB. Genetic polymorphisms of the beta 2adrenergic receptor in nocturnal and nonnocturnal asthma. Evidence that Gly16 correlates with the nocturnal phenotype. Journal of Clinical Investigation. 1995;95(4):1635-1641. doi:10.1172/JCI117838

34. Martinez FD, Graves PE, Baldini M, Solomon S, Erickson R. Association between Genetic Polymorphisms of the beta2-Adrenoceptor and Response to Albuterol in Children with and without a History of Wheezing. Journal of Clinical Investigation. 1997;100(12):3184-3188.

35. Santillan AA, Camargo CA, Ramirez-Rivera A, Delgado-Enciso I, Rojas-Martinez A, Cantu-Diaz F, Barrera-Saldana HA. Association between beta2-adrenoceptor polymorphisms 
and asthma diagnosis among Mexican adults. The Journal of allergy and clinical immunology. 2003;112(6):1095-100. doi:10.1016/j.jaci.2003.09.029

36. Cordell HJ. Detecting gene-gene interactions that underlie human diseases. Nature reviews. Genetics. 2009;10(6):392-404. doi:10.1038/nrg2579

37. Christ P, Sowa AS, Froy O, Lorentz A. The Circadian Clock Drives Mast Cell Functions in Allergic Reactions. Frontiers in immunology. 2018;9:1526.

doi:10.3389/fimmu.2018.01526

38. Ince LM, Zhang Z, Beesley S, Vonslow RM, Saer BR, Matthews LC, Begley N, Gibbs JE, Ray DW, Loudon ASI. Circadian variation in pulmonary inflammatory responses is independent of rhythmic glucocorticoid signaling in airway epithelial cells. FASEB journal: official publication of the Federation of American Societies for Experimental Biology. 2018 Jul 2:fj201800026RR. doi:10.1096/fj.201800026RR

39. Pulkkinen V, Ezer S, Sundman L, Hagström J, Remes S, Söderhäll C, Greco D, Dario G, Haglund C, Kere J, et al. Neuropeptide S receptor 1 (NPSR1) activates cancer-related pathways and is widely expressed in neuroendocrine tumors. Virchows Archiv: an international journal of pathology. 2014;465(2):173-83. doi:10.1007/s00428-014-1602-x 40. Ward LD, Kellis M. HaploReg v4: systematic mining of putative causal variants, cell types, regulators and target genes for human complex traits and disease. Nucleic Acids Research. 2016;44(D1):D877-D881. doi:10.1093/nar/gkv1340

41. Rayees S, Malik F, Bukhari SI, Singh G. Linking GATA-3 and interleukin-13: implications in asthma. Inflammation Research. 2014;63(4):255-265. doi:10.1007/s00011013-0700-6

42. Hosoda H, kato K, Asano H, Ito M, Kato H, Iwamoto T, Suzuki A, Masushige S, Kida S. $\mathrm{CBP} / \mathrm{p} 300$ is a cell type-specific modulator of CLOCK/BMAL1-mediated transcription. 
577 Molecular Brain. 2009;2(1):34. doi:10.1186/1756-6606-2-34

578 43. Lech K, Ackermann K, Revell VL, Lao O, Skene DJ, Kayser M. Dissecting Daily and 579 Circadian Expression Rhythms of Clock-Controlled Genes in Human Blood. Journal of $580 \quad$ Biological Rhythms. 2016;31(1):68-81. doi:10.1177/0748730415611761 581 582 


\section{FIGURES}

Figure 1. Schematic depiction of the cohorts and patients involved. Excluded patients and the reason for exclusion from analyses are written on white background. Grey background indicates included patients. All non-asthmatics served as controls when evaluating the effect of the two genes on asthma and only non-asthmatics without nocturnal symptoms served as controls when the nocturnal phenotypes were the outcome. Thus, patients without information on their nocturnal asthma status were excluded for stratified analyses on the impact of nocturnal symptoms.

Figure 2. Heat map of the interaction results of $R O R A * N P S R 1$ on asthma in MAGICS/ISAAC. Color explanation to the right. Darker colors indicate stronger associations. SNPs obtained from the regular GWAS dataset are highlighted in dark grey, imputed SNPs are highlighted in light grey.

\section{Figure 3. Heat map of the interaction results of $R O R A * N P S R 1$ on asthma with and asthma} without nocturnal symptoms in MAGICS/ISAAC. Color coding is explained on the right. Green colors indicate a significant interaction when asthma with nocturnal symptoms was the outcome whereas orange and red colors indicate a significant interaction when asthma without nocturnal symptoms was the outcome. Cells in yellow mark interactions which are significantly associated with both outcomes. Darker colors indicate a stronger association. SNPs obtained from the regular GWAS dataset are highlighted in dark grey, imputed SNPs are highlighted in light grey. 
607 
9 Odds ratios, $95 \%$ confidence intervals and $p$-values are reported for all datasets. $P$-values of

\section{Nocturnal asthma is affected by genetic interactions between}

\section{RORA and NPSRI}

Gaertner et al.

\section{TABLES}

Table 1. Significant interaction results $(R O R A * N P S R 1)$ on asthma in all cohorts.

\begin{tabular}{|c|c|c|c|}
\hline Interaction on asthma $^{a}$ & MAGICS/ISAAC & MAAS & BAMSE \\
\hline rs $2899662 *$ rs 887020 & $1.34(1.06-1.7) 0.015$ & $1.46(1.02-2.09) \mathbf{0 . 0 4 0 7}$ & $1.41(1.06-1.87) 0.018$ \\
\hline rs $2899662 *$ rs963218 & $1.39(1.1-1.75) 0.006$ & $1.29(0.9-1.83) 0.162$ & $1.33(1.01-1.75) \mathbf{0 . 0 4 5}$ \\
\hline rs2899662 * rs324396 & $0.72(0.55-0.93) \mathbf{0 . 0 1 3 5}$ & $0.61(0.41-0.92) \mathbf{0 . 0 1 6 6}$ & $0.82(0.61-1.1) 0.1836$ \\
\hline rs $8042149 *$ rs714588 & $1.27(1.01-1.59) \mathbf{0 . 0 4 1}$ & $1.02(0.72-1.45) 0.9143$ & $1.58(1.2-2.09) \mathbf{0 . 0 0 1 2}$ \\
\hline rs $4775301 *$ rs714588 & $1.29(1.03-1.61) \mathbf{0 . 0 2 5}$ & $1.14(0.8-1.63) 0.4583$ & $1.39(1.05-1.84) \mathbf{0 . 0 2 0}$ \\
\hline rs4775301* rs324396 & $0.73(0.57-0.93) 0.0116$ & $0.7(0.48-1.02) 0.0605$ & $0.9(0.67-1.2) 0.4701$ \\
\hline $\operatorname{rs} 12591848^{b} * \operatorname{rs} 2530547^{c}$ & $0.54(0.36-0.8) \mathbf{0 . 0 0 2 5}$ & $0.81(0.42-1.55) 0.5228$ & $0.71(0.48-1.06) 0.092$ \\
\hline rs12591848 ${ }^{\mathrm{b}} * \mathrm{rs} 963218$ & $0.51(0.35-0.74) 4.60 \mathrm{e}-04$ & $0.65(0.36-1.18) 0.1603$ & $0.71(0.47-1.06) 0.090$ \\
\hline rs4775289* rs963218 & $1.26(1.01-1.58) \mathbf{0 . 0 4 2 8}$ & $1.09(0.78-1.52) 0.6272$ & $1.3(0.99-1.71) 0.058$ \\
\hline rs $11071561 *$ rs 727162 & $1.33(1-1.76) 0.0471$ & $1.52(0.99-2.33) 0.0557$ & $1.02(0.73-1.43) 0.8856$ \\
\hline rs7171681* rs963218 & $1.39(1.09-1.77) \mathbf{0 . 0 0 8 5}$ & $1.01(0.69-1.47) 0.9544$ & $1.28(0.98-1.69) 0.075$ \\
\hline
\end{tabular}
significant interactions are in bold letters and the background is marked green; borderline significant interactions are marked in olive green and $p$-values are in italic. ${ }^{\mathrm{a}}$ The interaction is shown in the following format: RORA-SNP * NPSR1-SNP. ${ }^{\mathrm{b}}$ rs12591848 was replaced by rs746241 in BAMSE (SNPs are reported to be in perfect LD). ${ }^{\mathrm{c}}$ This interaction was significant in the recent paper by Acevedo et al ${ }^{23}$ using BAMSE and PARSIFAL populations. Looking only at the BAMSE cohort the interaction is less powerful and therefore, does not reach statistical significance. 
Table 2. Replication of interaction effects between RORA and NPSR1 on nocturnal asthma symptoms.

\begin{tabular}{|c|c|c|c|}
\hline Interaction $^{\text {a }}$ & $\begin{array}{c}\mathbf{N A S}^{\mathbf{b}} \\
(\mathrm{MAGICS} / \mathrm{ISAAC})\end{array}$ & $\begin{array}{l}\mathbf{N A S}^{\mathbf{b}} \\
(\mathrm{MAAS})\end{array}$ & $\begin{array}{c}\text { NBD }^{\mathbf{b}} \\
(\text { BAMSE) }\end{array}$ \\
\hline rs $1379928 *$ rs4775292 & $1.68(1.08-2.6) 0.02$ & $2.11(1.16-3.84) \mathbf{0 . 0 1 4 3}$ & $1.23(0.76-1.97) 0.3974$ \\
\hline rs $1379928 *$ rs 12437690 & $0.62(0.39-0.97) \mathbf{0 . 0 3 6}$ & $0.53(0.3-0.93) \mathbf{0 . 0 2 5 4}$ & $0.86(0.54-1.37) 0.5355$ \\
\hline rs $1379928 *$ rs 17204454 & $1.59(1.04-2.43) \mathbf{0 . 0 3 1 8}$ & $1.99(1.14-3.46) 0.0149$ & $1.11(0.71-1.75) 0.644$ \\
\hline rs324384* rs2899662 & $0.65(0.44-0.96) \mathbf{0 . 0 3 1 7}$ & $0.6(0.36-0.98) \mathbf{0 . 0 3 9 5}$ & $0.97(0.67-1.41) 0.8682$ \\
\hline rs324957 * rs2899662 & $0.65(0.44-0.96) \mathbf{0 . 0 3 2}$ & $0.56(0.34-0.91) \mathbf{0 . 0 2}$ & na \\
\hline rs $324396 *$ rs 2899662 & $0.61(0.4-0.95) \mathbf{0 . 0 2 7 7}$ & $0.48(0.28-0.82) \mathbf{0 . 0 0 6 9}$ & $0.73(0.49-1.1) 0.1309$ \\
\hline rs $324396 *$ rs 7171681 & $0.45(0.28-0.73) \mathbf{0 . 0 0 1 3}$ & $0.54(0.3-0.99) \mathbf{0 . 0 4 5 9}$ & $0.82(0.54-1.24) 0.3384$ \\
\hline rs324396 * rs341382 & $0.52(0.32-0.85) \mathbf{0 . 0 0 9 4}$ & $0.58(0.31-1.07) 0.0825$ & $0.9(0.58-1.4) 0.649$ \\
\hline rs324396 * rs4775301 & $0.65(0.44-0.96) \mathbf{0 . 0 3 0 7}$ & $0.63(0.38-1.03) 0.065$ & $0.87(0.6-1.28) 0.4886$ \\
\hline rs $2609234 *$ rs 341382 & $1.74(1.03-2.93) \mathbf{0 . 0 3 7 6}$ & $1.88(0.96-3.7) 0.0675$ & na \\
\hline rs $963218^{*}$ rs $12591848^{c}$ & $0.46(0.25-0.84) \mathbf{0 . 0 1 0 8}$ & $0.77(0.37-1.6) 0.4834$ & $0.6(0.35-1.05) 0.0759$ \\
\hline rs324981* rs11071561 & $1.51(1.07-2.13) \mathbf{0 . 0 2}$ & $1.57(0.99-2.5) 0.0577$ & na \\
\hline rs740347 * rs4775289 & $1.67(1.02-2.73) 0.041$ & $1.03(0.56-1.92) 0.9164$ & $1.65(0.97-2.8) 0.0646$ \\
\hline
\end{tabular}

$21{ }^{\mathrm{a}}$ The interaction is shown in the following format: NPSR $1-\mathrm{SNP} * R O R A-\mathrm{SNP} .{ }^{\mathrm{b}} \mathrm{NAS}=$ 22 nocturnal asthma symptoms; NBD = nocturnal breathing difficulties. ${ }^{\mathrm{c}}$ rs12591848 was 23 replaced by rs746241 in BAMSE (SNPs are reported to be in perfect LD). Odds ratios, 95\% 24 confidence intervals and $p$-values are reported for all datasets, $p$-values of significant 25 interactions are in bold letters and green background, borderline significant $p$-values are 26 marked in italic and cells are shaded olive green. na = interaction could not be calculated as at 27 least one of the SNPs was not available in the BAMSE cohort. 
Table 3A. Functional relevance of selected top hits in NPSR1 interacting to be associated with nocturnal asthma symptoms.

\begin{tabular}{|c|c|c|c|c|c|c|c|c|}
\hline SNP & Gene & $\begin{array}{l}\mathbf{N} \\
\mathbf{I A}\end{array}$ & $\begin{array}{l}\text { N IA } \\
\text { replicated }\end{array}$ & Location & $\begin{array}{l}\text { Predicted promoter } \\
\text { region? }\end{array}$ & $\begin{array}{c}\text { SNP } \\
\text { conserved }\end{array}$ & eQTL & TFBS \\
\hline rs 1379928 & NPSR 1 & 9 & 3 & Intron & $\mathrm{BRN}(\mathrm{LD} 0.88)$ & LD (0.99) & $\begin{array}{l}\text { gene expression change of } \\
A B C A 7, G N B 2 L 1, S L C 4 A 2 \\
\text { in PBMC (LD 0.92) }\end{array}$ & $\begin{array}{l}\text { CFOS,STAT3,P300 } \\
\text { (LD 0.81) }\end{array}$ \\
\hline rs324396 & NPSR 1 & 5 & $2(4)$ & $\begin{array}{l}\text { Intron NPSR1 / } \\
\text { exon NCAPD2P1 }\end{array}$ & $\begin{array}{l}\text { LNG, CRVX, LIV } \\
\text { (LD 0.98) }\end{array}$ & -- & 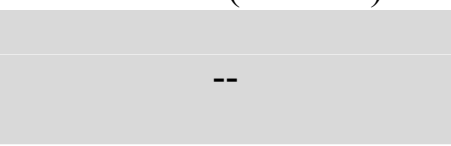 & $\begin{array}{l}26 \text { proteins, e.g. } \\
\text { GATA3 and STAT3 } \\
\text { (LD 0.98) }\end{array}$ \\
\hline rs6972158 & NPSR 1 & 10 & 0 & $\begin{array}{l}\text { Missense / Splicing } \\
\text { site }\end{array}$ & -- & yes & $\begin{array}{l}\text { eQTL of NPSR1 in Testis } \\
\text { (LD 0.8) }\end{array}$ & 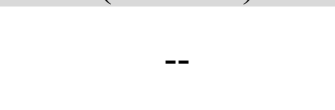 \\
\hline rs 1419779 & NPSR 1 & 9 & 0 & Intron & $\begin{array}{c}\text { GI, PANC, LIV (LD } \\
0.99)\end{array}$ & -- & $\begin{array}{c}\text { gene expression change of } \\
\text { DPY19L1 in blood }\end{array}$ & $\begin{array}{c}\text { MAFF, MAFK (LD } \\
0.99)\end{array}$ \\
\hline
\end{tabular}

Table 3B. Functional relevance of selected top hits in RORA interacting to be associated with nocturnal asthma symptoms.

\begin{tabular}{|c|c|c|c|c|c|c|c|c|}
\hline SNP & Gene & $\begin{array}{r}\mathbf{N} \\
\mathbf{I A}\end{array}$ & $\begin{array}{l}\text { N IA } \\
\text { replicated }\end{array}$ & Location & $\begin{array}{l}\text { Predicted promoter } \\
\text { region? }\end{array}$ & $\begin{array}{c}\text { SNP } \\
\text { conserved }\end{array}$ & eQTL & TFBS \\
\hline rs2899662 & $R O R A$ & 5 & 3 & Intron & BLD, MUS (LD 0.95) & -- & $\begin{array}{c}\text { differential exon level expression of } R O R A \\
\text { in brain cortex }\end{array}$ & USF1 (LD 0.85) \\
\hline rs7171681 & RORA & 11 & 1 & Intron & BLD & LD (0.97) & -- & STAT3 (LD 0.98) \\
\hline rs4775301 & $R O R A$ & 8 & $0(1)$ & Intron & BLD (LD 0.82) & -- & $C T C F, N R S F$ (LD 0.82) & -- \\
\hline rs8042149 & RORA & 8 & 0 & Intron & -- & -- & -- & -- \\
\hline rs4775289 & $R O R A$ & 7 & $0(1)$ & Intron & -- & -- & -- & -- \\
\hline rs341382 & RORA & 6 & $0(2)$ & Intron & ESC, BLD (LD 0.95) & -- & STAT3 (LD 0.97) & -- \\
\hline
\end{tabular}


Information was obtained from several databases as indicated in the methods section. All SNPs interacting with at least $25 \%$ of the other gene's SNPs in the discovery cohort or with at least two significant replications were included (N=10). If a SNP in LD was associated with a functional change, 'LD' and the respective $r^{2}$ value is put in brackets. The count of replicated interactions includes the replications with a $p<0.05$ and the replications with borderline significance $(\mathrm{p}<0.10)$ in brackets. Predicted promoter region is reported if the SNP was predicted to be located in a promoter region in a selected tissue. For an exact explanation of the columns please refer to the methods section. Part A includes SNPs from NPSR1 and Part B includes SNPs from RORA.

Abbreviations: N - number, IA - Interaction, eQTL - expression quantitative trait loci, TFBS - Transcription Factor Binding Site, LD - Linkage Disequilibrium, LIV - Liver, BRN - Brain, LNG - Lung, CRVX - Cervix, GI - Gastrointestinal Tract, PANC - Pancreas, BLD - Blood, MUS Muscle, PBMC - peripheral blood monocytes. 


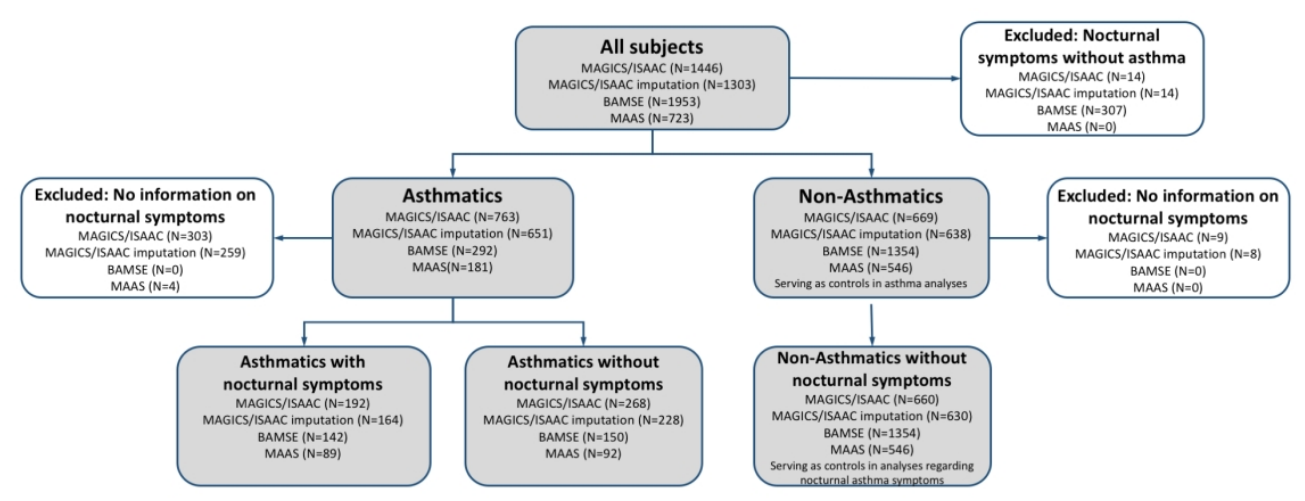

Figure 1. Schematic depiction of the cohorts and patients involved. Excluded patients and the reason for exclusion from analyses are written on white background. Grey background indicates included patients. All non-asthmatics served as controls when evaluating the effect of the two genes on asthma and only nonasthmatics without nocturnal symptoms served as controls when the nocturnal phenotypes were the outcome. Thus, patients without information on their nocturnal asthma status were excluded for stratified analyses on the impact of nocturnal symptoms.

$166 \times 65 \mathrm{~mm}(300 \times 300 \mathrm{DPI})$ 


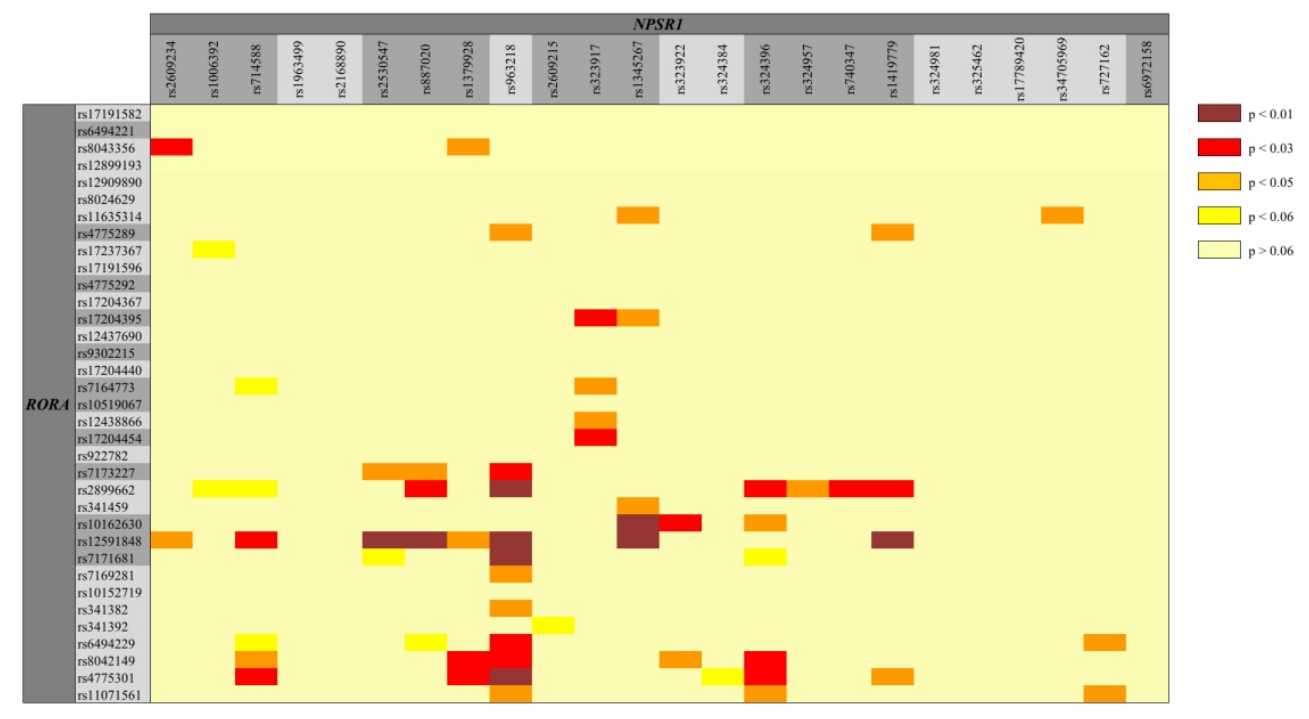

Figure 2. Heat map of the interaction results of RORA*NPSR1 on asthma in MAGICS/ISAAC. Color explanation to the right. Darker colors indicate stronger associations. SNPS obtained from the regular GWAS dataset are highlighted in dark grey, imputed SNPs are highlighted in light grey.

$161 \times 88 \mathrm{~mm}(300 \times 300 \mathrm{DPI})$ 


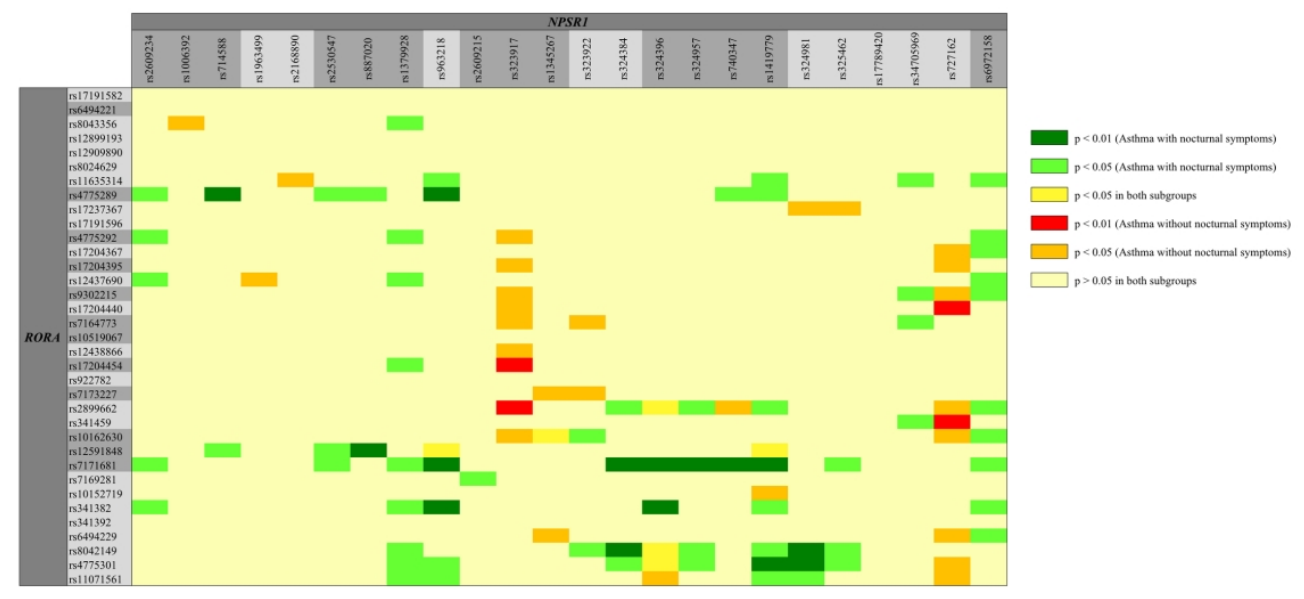

Figure 3. Heat map of the interaction results of RORA*NPSR1 on asthma with and asthma without nocturnal symptoms in MAGICS/ISAAC. Color coding is explained on the right. Green colors indicate a significant interaction when asthma with nocturnal symptoms was the outcome whereas orange and red colors indicate a significant interaction when asthma without nocturnal symptoms was the outcome. Cells in yellow mark interactions which are significantly associated with both outcomes. Darker colors indicate a stronger association. SNPS obtained from the regular GWAS dataset are highlighted in dark grey, imputed SNPS are highlighted in light grey.

$190 \times 85 \mathrm{~mm}(300 \times 300$ DPI $)$ 
$1 \quad$ Nocturnal asthma is affected by genetic interactions between RORA and NPSRI

Gaertner et al.

\section{FIGURES}

7 Figure 1. Schematic depiction of the cohorts and patients involved. Excluded patients and

8 the reason for exclusion from analyses are written on white background. Grey background

9 indicates included patients. All non-asthmatics served as controls when evaluating the effect

10 of the two genes on asthma and only non-asthmatics without nocturnal symptoms served as

11 controls when the nocturnal phenotypes were the outcome. Thus, patients without information

12 on their nocturnal asthma status were excluded for stratified analyses on the impact of 13 nocturnal symptoms.

14

Figure 2. Heat map of the interaction results of $R O R A^{*} N P S R 1$ on asthma in MAGICS/ISAAC. Color explanation to the right. Darker colors indicate stronger associations. SNPs obtained from the regular GWAS dataset are highlighted in dark grey, imputed SNPs are highlighted in light grey.

Figure 3. Heat map of the interaction results of $R O R A^{*} N P S R 1$ on asthma with and asthma without nocturnal symptoms in MAGICS/ISAAC. Color coding is explained on the right. Green colors indicate a significant interaction when asthma with nocturnal symptoms was the outcome whereas orange and red colors indicate a significant interaction when asthma without nocturnal symptoms was the outcome. Cells in yellow mark interactions 
25 which are significantly associated with both outcomes. Darker colors indicate a stronger

26 association. SNPs obtained from the regular GWAS dataset are highlighted in dark grey, 27 imputed SNPs are highlighted in light grey.

28

29

30 


\section{Nocturnal asthma is affected by genetic interactions between}

\section{RORA and NPSR1}

Vincent D. Gaertner ${ }^{1}$, Sven Michel ${ }^{1}$, John A. Curtin ${ }^{2}$, Ville Pulkkinen ${ }^{3}$, Nathalie Acevedo ${ }^{4,5}$, Cilla Söderhäll ${ }^{6,7}$, Andrea von Berg ${ }^{8}$, Albrecht Bufe ${ }^{9}$, Otto Laub ${ }^{10}$, Ernst Rietschel ${ }^{11}$, Andrea Heinzmann ${ }^{12}$, Burkard Simma ${ }^{13}$, Christian Vogelberg ${ }^{14}$, Göran Pershagen ${ }^{15}$, Erik Melén ${ }^{5,15}$, Angela Simpson ${ }^{2}$, Adnan Custovic ${ }^{16}$, Juha Kere ${ }^{6,17}$, and Michael Kabesch ${ }^{1 *}$

\section{ONLINE SUPPLEMENT}

\section{Participant flow}

In MAGICS/ISAAC, we excluded 8 subjects with no asthma diagnosis and 14 subjects with reported nocturnal symptoms but no diagnosed asthma, thus leaving 1,432 subjects for analysis. In BAMSE, 80 subjects without information on asthma diagnosis and 307 subjects with reported nocturnal symptoms but no diagnosed asthma were excluded, thus leaving 1,646 subjects for analyses. In MAAS, children with only one or two of the three features used to differentiate asthmatics and controls were excluded from further analyses, leaving 723 children in this study. For a more detailed description of all cohorts, please see Figure 1 and Supplementary Table S1. 
Since both genes under review are relatively large, SNPs were selected for analysis according to a stringent and conservative approach. Firstly, we included all SNPs from both genes that had been selected in a recent study on the interaction of RORA and NPSRI ${ }^{1}$. Based on a stringent literature search we then added SNPs that had been reported to be associated with asthma but were not covered by the aforementioned study (the search was performed on April $28^{\text {th }} 2018$ and the search terms were "asthma[Title] AND GPRA [All Fields] AND polymorphism [All Fields]" and "asthma[Title] AND NPSR1 [All Fields] AND polymorphism [All Fields]" and "asthma[Title] AND RORA [All Fields] AND polymorphism [All Fields]"). SNPs included in the analyses were obtained from the following studies: ${ }^{2-11}$. The SNP selection is depicted in Supplementary Figure S1. In total, 59 SNPs were selected. Of these, 22 SNPs had been originally genotyped in our GWAS dataset ${ }^{12}$. We then selected SNPs in perfect LD $\left(\mathrm{r}^{2}=1\right)$ with one of the SNPs under consideration $(\mathrm{N}=4$; based on a search in SnapProxy with 1000 Genomes data as reference panel). For the remaining 33 SNPs we used imputation data on the basis of the 1000 Genomes dataset as described below.

\section{Genotyping and imputation}

Genotyping was performed by using the Illumina Sentrix HumanHap300 BeadChip for MAGICS/ISAAC (imputation data was used when no original genotyping information was available) ${ }^{12,13}$. The iPLEX chemistry and the SEQUENOM platform at the Mutation Analysis Facility at Karolinska Institutet (BAMSE) and the Illumina 610 quad and subsequent imputation with the 1000 Genomes Phase 3 reference genome (MAAS) were used for the replication cohorts. 


\section{SUPPORTING FILES}

Supplementary Figure S1. Schematic depiction of the SNP selection process. SNPs marked with an asterisk either showed no association with asthma or were already included in the publication by Acevedo et al.

\section{Supplementary Figure S2. Heat map of the interaction results of $R O R A^{*} N P S R 1$ on} asthma with nocturnal symptoms and on asthma severity in MAGICS/ISAAC. Color coding is explained on the right. Green colors indicate a significant interaction when asthma with nocturnal symptoms was the outcome whereas blue colors indicate a significant interaction when severe asthma was the outcome. Cells in turquoise mark interactions which significantly influenced both outcomes. Darker colors indicate a stronger association. SNPs obtained from the regular GWAS dataset are highlighted in dark grey, imputed SNPs are highlighted in light grey.

\section{Supplementary Figure S3. Linkage disequilibrium (LD) plot from the selected region} from NPSR1 within MAGICS/ISAAC. $\mathrm{R}^{2}$-values are depicted and darker shades indicate a higher LD. The localization of all analyzed SNPs is depicted above the LD structure. Exons, introns, and the 5' untranslated region (UTR) are highlighted.

\section{Supplementary Figure S4. Linkage disequilibrium (LD) plot from the selected region} from RORA within MAGICS/ISAAC. $\mathrm{R}^{2}$-values are depicted and darker shades indicate a higher LD. The localization of all analyzed SNPs is depicted above the LD structure. Exons, introns, and the 5' untranslated region (UTR) are highlighted. 
Supplementary Figure S5. SNP selection for the functional database search.

* = with at least three SNPs from the respective other gene; \# = one of these SNPs is already included in the other selection (thus, the overall number of selected SNPs is 10).

75

76 letters.

Supplementary Table S1. Descriptive characterization of the study populations. The characteristics of the regular dataset and the imputation dataset of the MAGICS/ISAAC cohort as well as the BAMSE and MAAS cohorts with all genotyped individuals included in the analysis are depicted for comparison. For MAAS, age is depicted for the visit closest to 11 years which was mainly used in this manuscript. Different definitions of the two phenotypes over the cohorts are discussed in the main text. ${ }^{*} \mathrm{n}=$ number affected/ number with data available. ${ }^{\dagger}$ BAMSE is a cohort study and all samples were collected when the individuals reached age 8 years. Abbreviations: SD - standard deviation.

\section{Supplementary Table S2. Interaction results of $R O R A$ * NPSR1-SNPs on asthma in}

MAGICS/ISAAC. Interaction results of RORA by NPSR 1 on asthma within MAGICS/ISAAC are depicted. Originally genotyped SNPs are marked in dark grey whereas imputed SNPs are marked in light grey. Odds ratios, $95 \%$ confidence intervals and $p$-values are reported for both publications. Each cell contains the results of the respective interaction in the format "OR $(95 \% \mathrm{CI}) \mathrm{p}$-value". $p$-values of significant interactions are marked in bold 
Supplementary Table S3. Complete replication results of $R O R A * N P S R 1$ interactions on asthma in BAMSE and MAAS. All SNPs with at least 3 significant interactions in the original cohort and their respective replication results in BAMSE and MAAS are shown. Interactions between $R O R A$ and NPSR 1 with the same effect direction in the replication dataset as in MAGICS/ISAAC are marked in shades of green, opposing effect directions are marked in shades of red. The darker the color the stronger the association. Odds ratios with $95 \%$ confidence intervals and $p$-values are depicted. Each cell contains the results of the respective interaction in the format "OR $(95 \% \mathrm{CI}) \mathrm{p}$-value".

\section{Supplementary Table S4. Direct association of SNPs in RORA and NPSR1 with} nocturnal asthma symptoms in MAGICS/ISAAC. Results for logistic regression of 59 SNPs on nocturnal asthma symptoms with age and sex as covariates. Non-asthmatic subjects with nocturnal symptoms were excluded for both analyses. Odds Ratios, 95\% confidence intervals and $p$-values are reported for each SNP. Significant $p$-values are indicated in bold. Abbreviations: Chr - Chromosome; Position - chromosomal position; SNP - single nucleotide polymorphism; MAF - minor allele frequency; $\mathrm{OR}$ - odds ratio; $\mathrm{CI}$ - confidence interval; Chip - Illumina BeadChip genotyping; MALDI - MALDI-TOF-MS genotyping.

\section{Supplementary Table S5. Interaction results of RORA * NPSR1-SNPs on asthma with} nocturnal symptoms in MAGICS/ISAAC. Interaction results of RORA by NPSR 1 after stratification. Subjects with asthma as well as nocturnal symptoms (N=164 in the imputation dataset; $\mathrm{N}=192$ in the regular dataset) were compared with non-asthmatics $(\mathrm{N}=630$ in the imputation dataset; $\mathrm{N}=660$ in the regular dataset) within MAGICS/ISAAC. SNPs from RORA are on the vertical axis while SNPs from NPSR1 are depicted horizontally. Originally 
genotyped SNPs are marked in dark grey whereas imputed SNPs are marked in light grey. Odds ratios, $95 \%$ confidence intervals and $p$-values reported for both publications. Each cell contains the results of the respective interaction in the format "OR $(95 \% \mathrm{CI}) \mathrm{p}$-value". $p$ -

121 values of significant interactions are marked in bold letters.

Supplementary Table S6. Complete replication results of $R O R A^{*} N P S R 1$ interactions on nocturnal asthma in BAMSE and MAAS. All SNPs with at least 3 significant interactions in the original cohort and their respective replication results in BAMSE and MAAS are shown. Interactions between RORA and NPSR 1 with the same effect direction in the replication dataset as in MAGICS/ISAAC are marked in shades of green, opposing effect

128 directions are marked in shades of red. The darker the color the stronger the association. Odds ratios with $95 \%$ confidence intervals and $p$-values are shown. Results of the respective interactions are depicted in the format "OR (95\% CI) p-value". asthma in MAAS at age 16. Interaction effects of RORA and NPSRI on nocturnal asthma at age 16 for all interactions with at least borderline significant effects on nocturnal asthma at age 11 are shown. Interactions between $R O R A$ and NPSR 1 with the same effect direction at age 16 as at age 11 are marked in shades of green, opposing effect directions are marked in shades of

137 red. The darker the color the stronger the association. Odds ratios with $95 \%$ confidence intervals 138 and $p$-values are shown. Results of the respective interaction are depicted in the format "OR 139 (95\% CI) p-value". 
141 Supplementary Table S8. Interaction results of $R O R A * N P S R 1-S N P s$ on asthma

142 without nocturnal symptoms in MAGICS/ISAAC. Interaction results of RORA by NPSR I

143 after stratification. Subjects with asthma but without nocturnal symptoms $(\mathrm{N}=228$ in the

144 imputation dataset; $\mathrm{N}=268$ in the regular dataset) were compared with non-asthmatics $(\mathrm{N}=630$

145 in the imputation dataset; $\mathrm{N}=660$ in the regular dataset) in MAGICS/ISAAC. SNPs from

$146 R O R A$ are on the vertical axis while SNPs from NPSR1 are depicted horizontally. Originally

147 genotyped SNPs are marked in dark grey whereas imputed SNPs are marked in light grey.

148 Odds ratios, $95 \%$ confidence intervals and $p$-values reported for both publications. Each cell

149 contains the results of the respective interaction in the format "OR (95\% CI) p-value". $p$ -

150 values of significant interactions are marked in bold letters.

Supplementary Table S9. Complete replication results of $R O R A * N P S R 1$ interactions on asthma without nocturnal symptoms in BAMSE and MAAS. All SNPs with at least 3 and MAAS are shown. Interactions between RORA and NPSR1 with the same effect direction in the replication dataset as in MAGICS/ISAAC are marked in shades of green, opposing effect directions are marked in shades of red. The darker the color the stronger the association. Odds ratios with $95 \%$ confidence intervals and $p$-values are shown. Results of the respective interactions are depicted in the format "OR $(95 \% \mathrm{CI}) \mathrm{p}$-value".

Supplementary Table S10. Interaction results of RORA * NPSR1-SNPs on severe asthma $R O R A$ are on the vertical axis while SNPs from NPSR1 are depicted horizontally. Originally 
165 Odds ratios, $95 \%$ confidence intervals and $p$-values reported for both publications. Each cell

166 contains the results of the respective interaction in the format "OR (95\% CI) p-value". p-

167 values of significant interactions are marked in bold letters.

169 Supplementary Table S11. Complete replication results of interaction effects between

170 RORA and NPSR1 on asthma severity. All SNPs with at least 3 significant interactions in

171 the original cohort and their respective replication results in BAMSE and MAAS are shown.

172 Interactions between RORA and NPSR 1 with the same effect direction in the replication

173 dataset as in MAGICS/ISAAC are marked in shades of green, opposing effect directions are

174 marked in shades of red. The darker the color the stronger the association. Estimates, standard

175 errors and $p$-values are reported for all datasets, $p$-values of significant interactions are in bold

176 letters. na = interaction could not be calculated as at least one of the SNPs was not available

177 in the BAMSE cohort.

178

179

180

181 


\section{REFERENCES}

183 1. Acevedo N, Sääf A, Söderhäll C, Melén E, Mandelin J, Pietras CO, Ezer S, Karisola P,

184 Vendelin J, Gennäs GB af, et al. Interaction between retinoid acid receptor-related orphan

185 receptor alpha (RORA) and neuropeptide S receptor 1 (NPSR1) in asthma. PloS one.

186 2013;8(4):e60111. doi:10.1371/journal.pone.0060111

2. Melén E, Bruce S, Doekes G, Kabesch M, Laitinen T, Lauener R, Lindgren CM, Riedler J,

Scheynius A, van Hage-Hamsten M, et al. Haplotypes of G Protein-coupled Receptor 154

189 Are Associated with Childhood Allergy and Asthma. American Journal of Respiratory and

190 Critical Care Medicine. 2005;171(10):1089-1095. doi:10.1164/rccm.200410-1317OC

191 3. Kormann MSD, Carr D, Klopp N, Illig T, Leupold W, Fritzsch C, Weiland SK, von Mutius

192 E, Kabesch M. G-Protein-coupled receptor polymorphisms are associated with asthma in a

193 large German population. American journal of respiratory and critical care medicine.

194 2005;171(12):1358-62. doi:10.1164/rccm.200410-1312OC

195 4. Castro-Giner F, de Cid R, Gonzalez JR, Jarvis D, Heinrich J, Janson C, Omenaas ER,

196 Matheson MC, Pin I, Antó JM, et al. Positionally cloned genes and age-specific effects in

197 asthma and atopy: an international population-based cohort study (ECRHS). Thorax.

198 2010;65(2):124-31. doi:10.1136/thx.2009.119628

199 5. Moffatt MF, Gut IG, Demenais F, Strachan DP, Bouzigon E, Heath S, von Mutius E,

200 Farrall M, Lathrop M, Cookson WOCM, et al. A large-scale, consortium-based genomewide 201 association study of asthma. The New England journal of medicine. 2010;363(13):1211-21.

202 doi:10.1056/NEJMoa0906312

203 6. Torgerson DG, Ampleford EJ, Chiu GY, Gauderman WJ, Gignoux CR, Graves PE, Himes

204 BE, Levin AM, Mathias RA, Hancock DB, et al. Meta-analysis of genome-wide association 205 studies of asthma in ethnically diverse North American populations. Nature genetics. 
2011;43(9):887-92.

7. Hersh CP, Raby BA, Soto-Quirós ME, Murphy AJ, Avila L, Lasky-Su J, Sylvia JS, Klanderman BJ, Lange C, Weiss ST, et al. Comprehensive testing of positionally cloned asthma genes in two populations. American journal of respiratory and critical care medicine. 2007;176(9):849-57. doi:10.1164/rccm.200704-5920C

8. Blakey JD, Sayers I, Ring SM, Strachan DP, Hall IP. Positionally cloned asthma susceptibility gene polymorphisms and disease risk in the British 1958 Birth Cohort. Thorax. 2009;64(5):381-7. doi:10.1136/thx.2008.102053

9. Ramasamy A, Kuokkanen M, Vedantam S, Gajdos ZK, Couto Alves A, Lyon HN, Ferreira MAR, Strachan DP, Zhao JH, Abramson MJ, et al. Genome-wide association studies of asthma in population-based cohorts confirm known and suggested loci and identify an additional association near HLA. PloS one. 2012;7(9):e44008. doi:10.1371/journal.pone.0044008

10. Vergara C, Jiménez S, Acevedo N, Martínez B, Mercado D, Gusmão L, Rafaels N, Hand T, Barnes KC, Caraballo L. Association of G-protein-coupled receptor 154 with asthma and total $\mathrm{IgE}$ in a population of the Caribbean coast of Colombia. Clinical and experimental allergy : journal of the British Society for Allergy and Clinical Immunology. 2009;39(10):1558-68. doi:10.1111/j.1365-2222.2009.03311.x

11. Daley D, Lemire M, Akhabir L, Chan-Yeung M, He JQ, McDonald T, Sandford A, Stefanowicz D, Tripp B, Zamar D, et al. Analyses of associations with asthma in four asthma population samples from Canada and Australia. Human genetics. 2009;125(4):445-59. doi:10.1007/s00439-009-0643-8

12. Moffatt MF, Kabesch M, Liang L, Dixon AL, Strachan D, Heath S, Depner M, von Berg A, Bufe A, Rietschel E, et al. Genetic variants regulating ORMDL3 expression contribute to 
230 the risk of childhood asthma. Nature. 2007;448(7152):470-3. doi:10.1038/nature06014

231 13. Michel S, Liang L, Depner M, Klopp N, Ruether A, Kumar A, Schedel M, Vogelberg C,

232 von Mutius E, von Berg A, et al. Unifying candidate gene and GWAS Approaches in Asthma.

233 PloS one. 2010;5(11):e13894. doi:10.1371/journal.pone.0013894

234 
Supplementary Table S1. Descriptive characterization of the study populations.

\begin{tabular}{|c|c|c|c|c|}
\hline Parameter & MAGICS/ISAAC & $\begin{array}{l}\text { MAGICS/ISAAC } \\
\text { imputation } \\
\text { dataset }\end{array}$ & MAAS & BAMSE \\
\hline Male sex, $\mathrm{n}^{*}(\%)$ & $838 / 1432(58.5)$ & 746/1289 (57.9) & $382 / 723(52.8)$ & $\begin{array}{c}1051 / 2033 \\
(51.7)\end{array}$ \\
\hline Age (years), mean (SD) & $10.3(2.2)$ & $10.3(2.1)$ & $11.5(0.5)$ & $8^{\dagger}$ \\
\hline Asthmatics, $\mathrm{n}^{*}(\%)$ & $763 / 1432(53.3)$ & $651 / 1289(50.5)$ & $177 / 723(24.5)$ & $\begin{array}{c}292 / 1646 \\
(17.7)\end{array}$ \\
\hline $\begin{array}{l}\text { Nocturnal asthmatics / } \\
\text { nocturnal breathing } \\
\text { difficulties, } \mathrm{n}^{*}(\%)\end{array}$ & $192 / 1120(17.1)$ & $164 / 1022(16.1)$ & $89 / 635(14.0)$ & $142 / 1646(8.6)$ \\
\hline
\end{tabular}


Supplementary Table S2. Interaction results of RORA * NPSR1-SNPs on asthma in MAGICS/ISAAC.

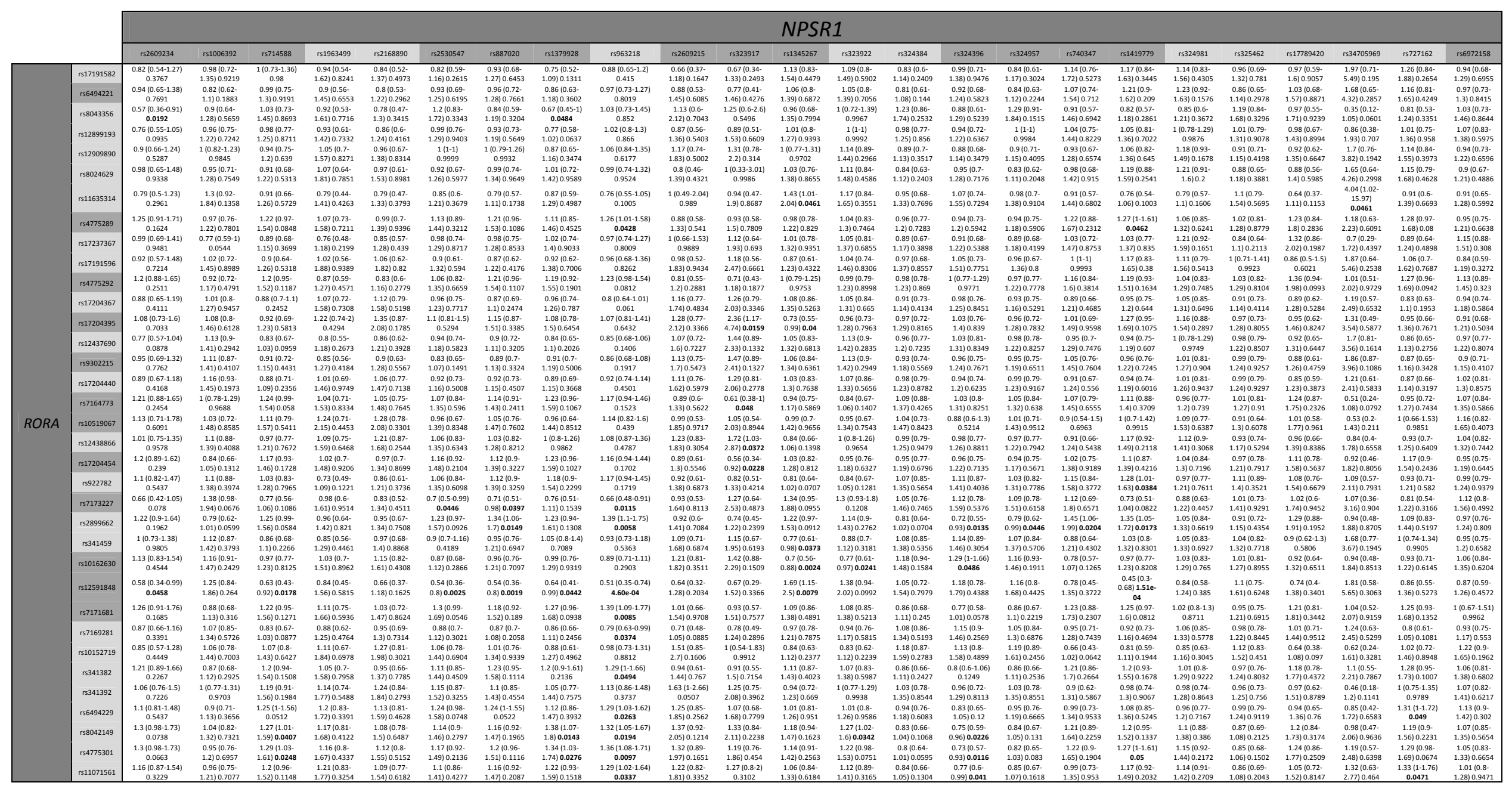


Supplementary Table S3. Complete replication results of RORA*NPSR1 interactions on asthma in BAMSE and MAAS.

effect direction different to MAGICS/ISAAC

effect direction the same as in MAGICS/ISAAC

borderline significant replication

significant replication of interaction on asthma

\begin{tabular}{|c|c|c|c|c|}
\hline RORA & NPSR1 & $\begin{array}{c}\text { Asthma } \\
\text { (MAGICS/ISAAC) }\end{array}$ & $\begin{array}{l}\text { Asthma } \\
\text { (BAMSE) }\end{array}$ & $\begin{array}{l}\text { Asthma } \\
\text { (MAAS) }\end{array}$ \\
\hline \multirow{3}{*}{ rs7173227 } & rs2530547 & $0.7(0.5-0.99) 0.0446$ & $0.75(0.54-1.05) 0.0934$ & $1.07(0.62-1.84) 0.8036$ \\
\hline & rs887020 & $0.71(0.51-0.98) 0.0397$ & $0.9(0.64-1.27) 0.5487$ & $0.83(0.5-1.37) 0.4622$ \\
\hline & rs963218 & $0.66(0.48-0.91) 0.0115$ & $0.74(0.53-1.04) 0.0814$ & $1.05(0.66-1.66) 0.8478$ \\
\hline \multirow{6}{*}{ rs2899662 } & rs 887020 & $1.34(1.06-1.7) 0.0149$ & $1.41(1.06-1.87) 0.0182$ & $1.46(1.02-2.09) 0.0407$ \\
\hline & rs963218 & $1.39(1.1-1.75) 0.0058$ & $1.33(1.01-1.75) 0.0448$ & $1.29(0.9-1.83) 0.162$ \\
\hline & rs324396 & $0.72(0.55-0.93) 0.0135$ & $0.82(0.61-1.1) 0.1836$ & $0.61(0.41-0.92) 0.0166$ \\
\hline & rs324957 & $0.79(0.62-0.99) 0.0446$ & na & $0.9(0.63-1.28) 0.5538$ \\
\hline & rs740347 & $1.45(1.06-1.99) 0.0204$ & $1.23(0.84-1.81) 0.2787$ & $0.97(0.59-1.6) 0.9012$ \\
\hline & rs1419779 & $1.35(1.05-1.72) 0.0173$ & na & $1.08(0.75-1.56) 0.6741$ \\
\hline \multirow{3}{*}{ rs10162630 } & rs1345267 & $0.7(0.56-0.88) 0.0024$ & na & $0.85(0.6-1.21) 0.3677$ \\
\hline & rs323922 & $0.77(0.61-0.97) 0.0241$ & $0.88(0.68-1.15) 0.3564$ & $0.8(0.57-1.12) 0.1864$ \\
\hline & rs324396 & $1.29(1-1.66) 0.0486$ & $1.16(0.88-1.55) 0.2963$ & $1.35(0.93-1.97) 0.1131$ \\
\hline \multirow{8}{*}{ rs12591848 } & rs2609234 & $0.58(0.34-0.99) \quad 0.0458$ & na & $1.87(0.9-3.87) 0.0922$ \\
\hline & rs714588 & $0.63(0.43-0.92) 0.0178$ & $0.65(0.43-0.98) 0.0412$ & $1.26(0.69-2.32) 0.4492$ \\
\hline & rs2530547 & $0.54(0.36-0.8) 0.0025$ & $0.71(0.48-1.06) 0.0915$ & $0.81(0.42-1.55) 0.5228$ \\
\hline & rs887020 & $0.54(0.36-0.8) 0.0019$ & $0.82(0.55-1.23) 0.3374$ & $0.75(0.4-1.43) 0.3883$ \\
\hline & rs1379928 & $0.64(0.41-0.99) 0.0442$ & $0.87(0.52-1.45) 0.5946$ & $1.29(0.64-2.58) 0.4725$ \\
\hline & rs963218 & $0.51(0.35-0.74) 4.60 \mathrm{e}-04$ & $0.71(0.47-1.06) 0.0897$ & $0.65(0.36-1.18) 0.1603$ \\
\hline & rs1345267 & $1.69(1.15-2.5) 0.0079$ & na & $1.08(0.64-1.83) 0.7668$ \\
\hline & rs1419779 & $0.45(0.3-0.68) 1.51 \mathrm{e}-04$ & na & $0.77(0.43-1.36) 0.3633$ \\
\hline \multirow{5}{*}{ rs8042149 } & rs714588 & $1.27(1.01-1.59) \mathbf{0 . 0 4 0 7}$ & $1.58(1.2-2.09) 0.0012$ & $1.02(0.72-1.45) 0.9143$ \\
\hline & rs1379928 & $1.38(1.07-1.8) 0.0143$ & $1.15(0.82-1.61) 0.4214$ & $0.85(0.58-1.25) 0.4141$ \\
\hline & rs963218 & $1.32(1.05-1.67) 0.0194$ & 1 (0.77-1.3) 0.9809 & $1.05(0.75-1.47) 0.7783$ \\
\hline & rs323922 & $1.27(1.02-1.6) 0.0342$ & $0.97(0.75-1.27) 0.8368$ & 0.99 (0.71-1.39) 0.9738 \\
\hline & rs324396 & $0.75(0.59-0.96) \mathbf{0 . 0 2 2 6}$ & $0.9(0.68-1.2) 0.4705$ & $0.8(0.55-1.15) 0.2267$ \\
\hline \multirow{5}{*}{ rs4775301 } & rs714588 & $1.29(1.03-1.61) 0.0248$ & $1.39(1.05-1.84) 0.0202$ & $1.14(0.8-1.63) 0.4583$ \\
\hline & rs1379928 & $1.34(1.03-1.74) 0.0276$ & $1.02(0.73-1.44) 0.9001$ & $0.84(0.56-1.25) 0.3898$ \\
\hline & rs963218 & $1.36(1.08-1.71) 0.0097$ & $1.01(0.77-1.33) 0.9379$ & $1.05(0.74-1.49) 0.7731$ \\
\hline & rs324396 & $0.73(0.57-0.93) 0.0116$ & $0.9(0.67-1.2) 0.4701$ & $0.7(0.48-1.02) 0.0605$ \\
\hline & rs1419779 & $1.27(1-1.61) 0.05$ & na & $1.01(0.71-1.45) 0.9444$ \\
\hline \multirow{2}{*}{ rs11071561 } & rs963218 & $1.29(1.02-1.64) 0.0337$ & $1.13(0.87-1.47) 0.3656$ & $1.32(0.91-1.9) 0.1392$ \\
\hline & rs324396 & $0.77(0.6-0.99) 0.041$ & $1.07(0.8-1.43) 0.6608$ & $0.62(0.42-0.93) 0.0191$ \\
\hline
\end{tabular}




\begin{tabular}{|c|c|c|c|c|}
\hline & rs727162 & $1.33(1-1.76) 0.0471$ & $1.02(0.73-1.43) 0.8856$ & $1.52(0.99-2.33) 0.0557$ \\
\hline rs8043356 & rs1379928 & $0.67(0.45-1) 0.0484$ & $1.01(0.64-1.6) 0.9664$ & $0.92(0.53-1.59) 0.7578$ \\
\hline rs4775289 & \multirow{5}{*}{ rs963218 } & $1.26(1.01-1.58) 0.0428$ & $1.3(0.99-1.71) 0.058$ & $1.09(0.78-1.52) 0.6272$ \\
\hline rs7171681 & & $1.39(1.09-1.77) 0.0085$ & $1.28(0.98-1.69) 0.0752$ & $1.01(0.69-1.47) 0.9544$ \\
\hline rs7169281 & & $0.79(0.63-0.99) 0.0374$ & $0.91(0.7-1.17) 0.461$ & $1.3(0.91-1.85) 0.156$ \\
\hline rs341382 & & $1.29(1-1.66) 0.0494$ & $1.26(0.95-1.67) 0.1072$ & $1.19(0.81-1.76) 0.373$ \\
\hline rs6494229 & & $1.29(1.03-1.62) \mathbf{0 . 0 2 6 3}$ & $1.12(0.87-1.46) 0.3811$ & $1.32(0.91-1.92) 0.1373$ \\
\hline rs17204395 & \multirow{4}{*}{ rs323917 } & $2.36(1.17-4.74) 0.0159$ & & $0.99(0.4-2.46) 0.9761$ \\
\hline rs7164773 & & $0.61(0.38-1) 0.048$ & $0.72(0.4-1.31) 0.2786$ & $0.87(0.39-1.91) 0.7251$ \\
\hline rs12438866 & & $1.72(1.03-2.87) 0.0372$ & $1.02(0.57-1.8) 0.9512$ & $1.35(0.65-2.82) 0.4265$ \\
\hline rs17204454 & & $0.56(0.34-0.92) 0.0228$ & $1.43(0.81-2.53) 0.223$ & $1.02(0.48-2.18) 0.9512$ \\
\hline rs11635314 & \multirow{3}{*}{ rs1345267 } & $1.43(1.01-2.04) 0.0461$ & na & $1.3(0.83-2.04) 0.2486$ \\
\hline rs17204395 & & $0.73(0.55-0.99) 0.04$ & na & $0.73(0.46-1.17) 0.1905$ \\
\hline rs341459 & & $0.77(0.61-0.98) 0.0373$ & na & $0.72(0.48-1.07) 0.1007$ \\
\hline rs4775289 & \multirow{2}{*}{ rs1419779 } & $1.27(1-1.61) 0.0462$ & na & $1.05(0.74-1.49) 0.7823$ \\
\hline rs922782 & & $1.28(1.01-1.63) 0.0384$ & na & $0.87(0.61-1.24) 0.436$ \\
\hline
\end{tabular}


Supplementary Table S4. Direct association of SNPs in RORA and NPSR1 with nocturnal asthma symptoms in MAGICS/ISAAC

\begin{tabular}{|c|c|c|c|c|c|c|c|c|c|}
\hline \multirow[b]{2}{*}{ Chr } & \multirow[b]{2}{*}{ SNP } & \multirow[b]{2}{*}{ Position } & \multirow[b]{2}{*}{ Dataset } & \multirow[b]{2}{*}{ Gene } & \multirow{2}{*}{$\begin{array}{l}\text { Minor } \\
\text { allele }\end{array}$} & \multirow[b]{2}{*}{ MAF } & \multirow[b]{2}{*}{$\mathbf{N}$} & \multicolumn{2}{|c|}{ Nocturnal asthma } \\
\hline & & & & & & & & OR (95\% CI) & $\begin{array}{c}p- \\
\text { value }\end{array}$ \\
\hline 7 & rs2609234 & 34648813 & MALDI & NPSR 1 & $T$ & 0,16 & 727 & $0.68(0.47-1.00)$ & 0,05 \\
\hline 7 & rs1006392 & 34651330 & MALDI & NPSR 1 & C & 0,43 & 733 & $1.04(0.80-1.34)$ & 0,76 \\
\hline 7 & rs714588 & 34653614 & MALDI & NPSR 1 & G & 0,44 & 734 & $0.79(0.61-1.03)$ & 0,076 \\
\hline 7 & rs1963499 & 34657848 & Imputed & NPSR1 & A & 0,1 & 794 & $0.97(0.64-1.46)$ & 0,88 \\
\hline 7 & rs2168890 & 34657860 & Imputed & NPSR 1 & $\mathrm{~T}$ & 0,13 & 794 & $0.88(0.60-1.30)$ & 0,51 \\
\hline 7 & rs 2530547 & 34658310 & MALDI & NPSR 1 & T & 0,36 & 792 & $0.98(0.76-1.26)$ & 0,85 \\
\hline 7 & rs887020 & 34658370 & MALDI & NPSR1 & A & 0,44 & 836 & $0.96(0.75-1.22)$ & 0,56 \\
\hline 7 & rs1379928 & 34661677 & Chip & NPSR 1 & G & 0,22 & 789 & $0.77(0.56-1.05)$ & 0,096 \\
\hline 7 & rs963218 & 34672157 & Imputed & NPSR 1 & A & 0,45 & 794 & $0.87(0.67-1.12)$ & 0,27 \\
\hline 7 & rs2609215 & 34676155 & Chip & NPSR 1 & c & 0,08 & 794 & $0.73(0.45-1.19)$ & 0,21 \\
\hline 7 & rs323917 & 34702031 & MALDI & NPSR 1 & G & 0,07 & 735 & $0.82(0.48-1.41)$ & 0,48 \\
\hline 7 & rs1345267 & 34708447 & Chip & NPSR 1 & G & 0,39 & 794 & $1.21(0.94-1.57)$ & 0,14 \\
\hline 7 & rs323922 & 34709170 & Imputed & NPSR 1 & C & 0,42 & 794 & $1.18(0.91-1.52)$ & 0,21 \\
\hline 7 & rs324384 & 34742415 & Imputed & NPSR 1 & C & 0,43 & 794 & $0.88(0.68-1.14)$ & 0,34 \\
\hline 7 & rs324396 & 34750511 & Chip & NPSR 1 & T & 0,3 & 759 & $0.89(0.68-1.18)$ & 0,44 \\
\hline 7 & rs324957 & 34761760 & Chip & NPSR 1 & A & 0,43 & 793 & $0.91(0.70-1.18)$ & 0,47 \\
\hline 7 & rs740347 & 34772690 & MALDI & NPSR 1 & C & 0,14 & 736 & $1.08(0.75-1.55)$ & 0,69 \\
\hline 7 & rs1419779 & 34773696 & Chip & NPSR1 & G & 0,34 & 794 & $0.97(0.75-1.27)$ & 0,85 \\
\hline 7 & rs324981 & 34778501 & Imputed & NPSR 1 & $\mathrm{~T}$ & 0,49 & 794 & $1.13(0.88-1.44)$ & 0,34 \\
\hline 7 & rs325462 & 34810234 & Imputed & NPSR 1 & A & 0,47 & 794 & $0.87(0.68-1.12)$ & 0,28 \\
\hline 7 & rs17789420 & 34813053 & Imputed & NPSR1 & A & 0,1 & 794 & $1.03(0.68-1.55)$ & 0,91 \\
\hline 7 & rs34705969 & 34827512 & Imputed & NPSR 1 & T & 0,03 & 794 & $1.85(0.90-3.81)$ & 0,092 \\
\hline 7 & rs727162 & 34834426 & Imputed & NPSR1 & G & 0,21 & 794 & $1.13(0.83-1.55)$ & 0,44 \\
\hline 7 & rs6972158 & 34849570 & MALDI & NPSR 1 & G & 0,33 & 834 & $0.77(0.59-0.99)$ & 0,048 \\
\hline 15 & rs17191582 & 60722975 & Imputed & RORA & G & 0,16 & 794 & $1.23(0.88-1.71)$ & 0,23 \\
\hline 15 & rs6494221 & 60723908 & Chip & RORA & C & 0,2 & 793 & $1.17(0.87-1.57)$ & 0,31 \\
\hline 15 & rs8043356 & 60723970 & Imputed & RORA & T & 0,14 & 794 & $1.10(0.76-1.59)$ & 0,63 \\
\hline 15 & rs12899193 & 60724097 & Imputed & RORA & C & 0,32 & 794 & $1.14(0.87-1.48)$ & 0,33 \\
\hline 15 & rs12909890 & 60725778 & Imputed & RORA & G & 0,37 & 794 & $1.34(1.03-1.74)$ & 0,0321 \\
\hline 15 & rs 8024629 & 60728055 & Imputed & RORA & A & 0,17 & 794 & $1.12(0.82-1.54)$ & 0,46 \\
\hline 15 & rs11635314 & 60736287 & Imputed & RORA & T & 0,13 & 794 & $1.06(0.72-1.57)$ & 0,76 \\
\hline 15 & rs4775289 & 60736677 & Chip & RORA & A & 0,43 & 794 & $0.94(0.73-1.22)$ & 0,64 \\
\hline 15 & rs17237367 & 60739770 & Imputed & RORA & A & 0,23 & 794 & $0.90(0.66-1.23)$ & 0,52 \\
\hline 15 & rs17191596 & 60743552 & Imputed & RORA & c & 0,12 & 794 & $1.40(0.99-1.98)$ & 0,059 \\
\hline 15 & rs4775292 & 60746874 & Chip & RORA & T & 0,39 & 794 & $0.80(0.61-1.04)$ & 0,094 \\
\hline
\end{tabular}




\begin{tabular}{|c|c|c|c|c|c|c|c|c|c|}
\hline 15 & rs17204395 & 60757882 & Chip & RORA & T & 0,18 & 794 & $1.14(0.83-1.56)$ & 0,4 \\
\hline 15 & rs12437690 & 60763233 & Imputed & RORA & A & 0,4 & 794 & $1.20(0.93-1.53)$ & 0,16 \\
\hline 15 & rs9302215 & 60768168 & Chip & RORA & T & 0,36 & 785 & $1.12(0.86-1.45)$ & 0,39 \\
\hline 15 & rs17204440 & 60773888 & Imputed & RORA & A & 0,49 & 794 & $1.11(0.86-1.43)$ & 0,44 \\
\hline 15 & rs7164773 & 60775749 & Chip & RORA & T & 0,5 & 794 & $0.86(0.67-1.10)$ & 0,24 \\
\hline 15 & rs10519067 & 60776148 & Chip & RORA & A & 0,13 & 793 & $0.98(0.67-1.44)$ & 0,92 \\
\hline 15 & rs12438866 & 60776321 & Imputed & RORA & c & 0,38 & 794 & $1.23(0.94-1.60)$ & 0,13 \\
\hline 15 & rs17204454 & 60776612 & Chip & RORA & c & 0,48 & 794 & $0.81(0.63-1.04)$ & 0,095 \\
\hline 15 & rs922782 & 60777984 & Imputed & RORA & G & 0,49 & 794 & $0.88(0.68-1.13)$ & 0,32 \\
\hline 15 & rs 7173227 & 60779075 & Chip & RORA & T & 0,14 & 789 & $1.15(0.80-1.64)$ & 0,45 \\
\hline 15 & rs2899662 & 60784020 & Imputed & RORA & $T$ & 0,37 & 794 & $0.86(0.66-1.13)$ & 0,28 \\
\hline 15 & rs341459 & 60788136 & Imputed & RORA & C & 0,3 & 794 & $1.01(0.77-1.33)$ & 0,92 \\
\hline 15 & rs10162630 & 60792529 & Chip & RORA & $T$ & 0,49 & 794 & $1.06(0.82-1.36)$ & 0,68 \\
\hline 15 & rs12591848 & 60793494 & Chip & RORA & A & 0,1 & 794 & $1.08(0.72-1.62)$ & 0,72 \\
\hline 15 & rs7171681 & 60819129 & Chip & RORA & C & 0,31 & 794 & $0.81(0.61-1.08)$ & 0,15 \\
\hline 15 & rs7169281 & 60821905 & Imputed & RORA & c & 0,49 & 794 & $1.07(0.84-1.36)$ & 0,59 \\
\hline 15 & rs10152719 & 60822458 & Imputed & RORA & T & 0,17 & 794 & $0.97(0.69-1.36)$ & 0,85 \\
\hline 15 & rs341382 & 60825632 & Imputed & RORA & C & 0,28 & 794 & $0.82(0.61-1.10)$ & 0,18 \\
\hline 15 & rs341392 & 60832036 & Imputed & RORA & c & 0,22 & 794 & $0.96(0.71-1.29)$ & 0,79 \\
\hline 15 & rs6494229 & 60832180 & Imputed & RORA & A & 0,47 & 794 & $0.93(0.73-1.20)$ & 0,59 \\
\hline 15 & rs8042149 & 60832754 & Imputed & RORA & $T$ & 0,45 & 794 & $0.96(0.75-1.23)$ & 0,74 \\
\hline 15 & rs4775301 & 60834660 & Imputed & RORA & T & 0,46 & 794 & $0.85(0.66-1.09)$ & 0,21 \\
\hline 15 & rs11071561 & 60839484 & Imputed & RORA & T & 0,41 & 794 & $0.93(0.72-1.21)$ & 0,6 \\
\hline
\end{tabular}


Supplementary Table S5. Interaction results of RORA * NPSR1-SNPs on asthma with nocturnal symptoms in MAGICS/ISAAC.

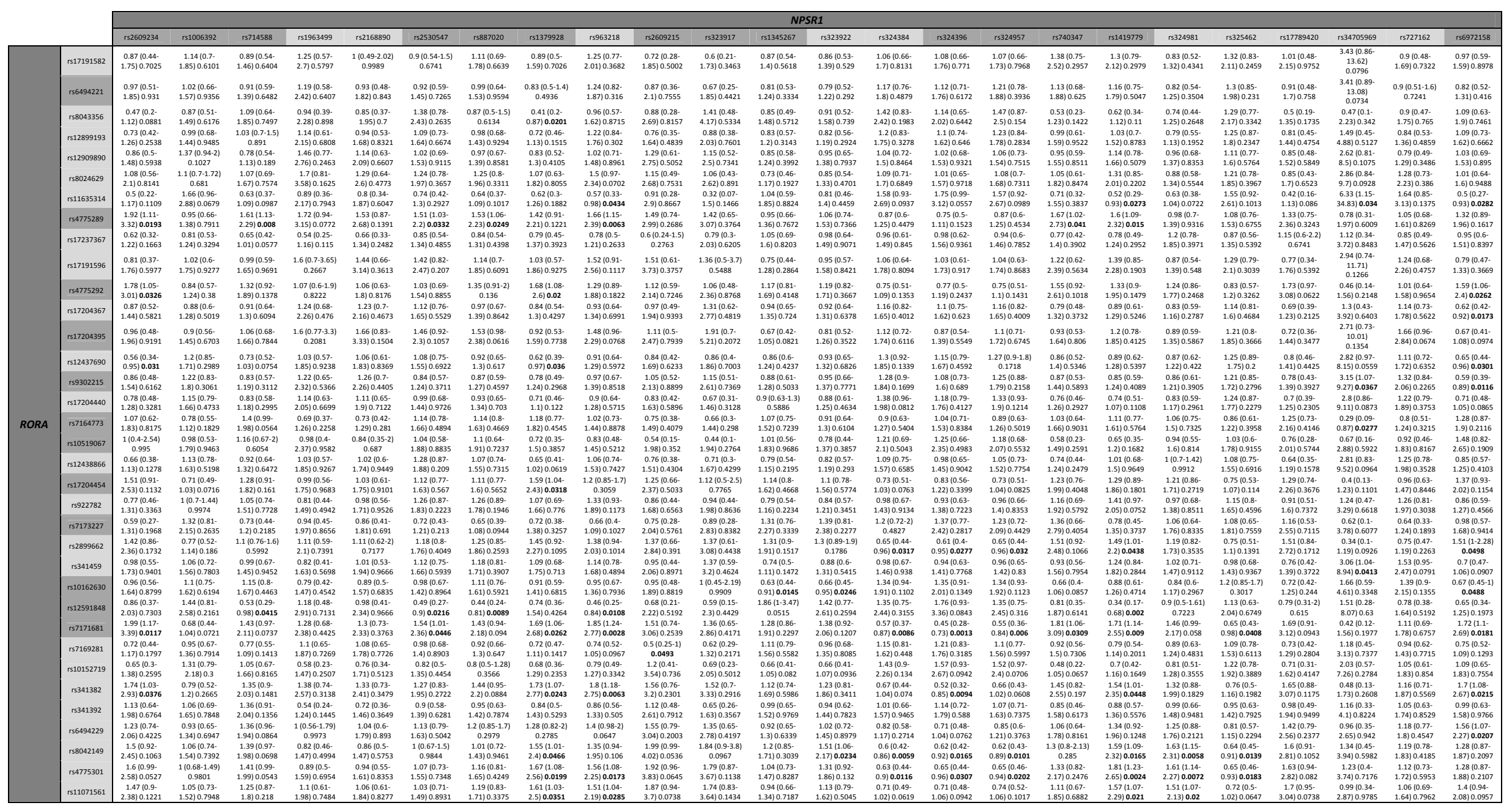


Supplementary Table S6. Complete replication results of RORA*NPSR1 interactions on nocturnal asthma in BAMSE and MAAS. effect direction different to MAGICS/ISAAC effect direction the same as in MAGICS/ISAAC borderline significant replication significant replication of interaction on nocturnal asthma

\begin{tabular}{|c|c|c|c|c|}
\hline \multirow{2}{*}{ NPSR1 } & \multirow{2}{*}{ RORA } & nocturnal asthma & nocturnal breathing difficulties & nocturnal symptoms at age 11 \\
\hline & & (MAGICS/ISAAC) & (BAMSE) & (MAAS) \\
\hline \multirow{5}{*}{ rs2609234 } & rs4775289 & $1.92(1.11-3.32) 0.0193$ & na & $1.28(0.74-2.2) 0.3733$ \\
\hline & rs4775292 & $1.78(1.05-3.01) 0.0326$ & na & $1.56(0.86-2.84) 0.1449$ \\
\hline & rs12437690 & $0.56(0.34-0.95) 0.031$ & na & $0.69(0.39-1.23) 0.2076$ \\
\hline & rs7171681 & $1.99(1.17-3.39) 0.0117$ & na & $1.72(0.89-3.32) 0.1057$ \\
\hline & rs341382 & $1.74(1.03-2.93) 0.0376$ & na & $1.88(0.96-3.7) 0.0675$ \\
\hline \multirow{3}{*}{ rs 2530547} & rs4775289 & $1.51(1.03-2.2) 0.0332$ & $0.98(0.68-1.43) 0.9296$ & $1.37(0.84-2.22) 0.2068$ \\
\hline & rs12591848 ${ }^{+}$ & $0.49(0.27-0.9) 0.0216$ & $0.77(0.44-1.32) 0.3357^{\ddagger}$ & $1.03(0.46-2.28) 0.9504$ \\
\hline & rs7171681 & $1.54(1.01-2.36) \mathbf{0 . 0 4 4 6}$ & $1.04(0.7-1.55) 0.8428^{\ddagger}$ & $1.1(0.61-1.97) 0.7497$ \\
\hline \multirow{9}{*}{ rs1379928 } & rs8043356 & $0.41(0.2-0.87) 0.0201$ & $1(0.55-1.8) 0.995$ & $0.75(0.37-1.53) 0.4323$ \\
\hline & rs4775292 & $1.68(1.08-2.6) 0.02$ & $1.23(0.76-1.97) 0.3974^{\ddagger}$ & $2.11(1.16-3.84) 0.0143$ \\
\hline & rs12437690 & $0.62(0.39-0.97) 0.036$ & $0.86(0.54-1.37) 0.5355^{\ddagger}$ & $0.53(0.3-0.93) 0.0254$ \\
\hline & rs17204454 & $1.59(1.04-2.43) 0.0318$ & $1.11(0.71-1.75) 0.644^{\ddagger}$ & $1.99(1.14-3.46) 0.0149$ \\
\hline & rs7171681 & $1.69(1.06-2.68) 0.0262$ & $1.16(0.7-1.93) 0.5688^{\ddagger}$ & $0.98(0.52-1.87) 0.9594$ \\
\hline & rs341382 & $1.73(1.07-2.77) 0.0243$ & $1.27(0.75-2.16) 0.3736^{\ddagger}$ & $1.06(0.54-2.06) 0.8696$ \\
\hline & rs8042149 & $1.55(1.01-2.4) 0.0466$ & $0.89(0.56-1.41) 0.6139$ & $0.99(0.6-1.62) 0.9658$ \\
\hline & rs4775301 & $1.67(1.08-2.56) 0.0199$ & $0.96(0.61-1.52) 0.8707$ & 1 (0.6-1.67) 0.9961 \\
\hline & rs11071561 & $1.61(1.03-2.5) 0.0351$ & $0.98(0.62-1.56) 0.9332$ & $0.87(0.49-1.55) 0.635$ \\
\hline \multirow{7}{*}{ rs963218 } & rs11635314 & $0.57(0.33-0.98) 0.0434$ & $0.79(0.47-1.33) 0.3752^{\ddagger}$ & $0.79(0.42-1.51) 0.48$ \\
\hline & rs4775289 & $1.66(1.15-2.39) 0.0063$ & $1.25(0.86-1.81) 0.2393^{\ddagger}$ & $1.1(0.71-1.72) 0.6672$ \\
\hline & rs12591848 ${ }^{\dagger}$ & $0.46(0.25-0.84) 0.0108$ & $0.6(0.35-1.05) 0.0759^{\ddagger}$ & $0.77(0.37-1.6) 0.4834$ \\
\hline & rs7171681 & $1.85(1.24-2.77) 0.0028$ & $1.23(0.84-1.8) 0.2797^{\ddagger}$ & $1.08(0.63-1.84) 0.7787$ \\
\hline & rs341382 & $1.8(1.18-2.75) 0.0063$ & $1.21(0.82-1.8) 0.3422^{\ddagger}$ & $1.4(0.81-2.43) 0.2333$ \\
\hline & rs4775301 & $1.56(1.08-2.25) 0.0173$ & $0.92(0.64-1.31) 0.6361$ & $1(0.63-1.58) 0.9862$ \\
\hline & rs11071561 & $1.51(1.04-2.19) 0.0285$ & $1.07(0.75-1.53) 0.7193^{\ddagger}$ & $1.22(0.75-1.97) 0.4257$ \\
\hline \multirow{4}{*}{ rs324384 } & rs2899662 & $0.65(0.44-0.96) 0.0317$ & $0.97(0.67-1.41) 0.8682^{\ddagger}$ & $0.6(0.36-0.98) 0.0395$ \\
\hline & rs7171681 & $0.57(0.37-0.87) \mathbf{0 . 0 0 8 6}$ & $0.88(0.59-1.3) 0.5256^{\ddagger}$ & $0.84(0.49-1.46) 0.5349$ \\
\hline & rs8042149 & $0.6(0.42-0.86) 0.0059$ & $1.07(0.75-1.52) 0.725$ & $0.93(0.6-1.46) 0.7683$ \\
\hline & rs4775301 & $0.63(0.44-0.9) 0.0116$ & $1.01(0.71-1.45) 0.9567$ & $0.87(0.55-1.36) 0.5365$ \\
\hline rs324396 & rs2899662 & $0.61(0.4-0.95) 0.0277$ & $0.73(0.49-1.1) 0.1309^{7}$ & $0.48(0.28-0.82) 0.0069$ \\
\hline
\end{tabular}




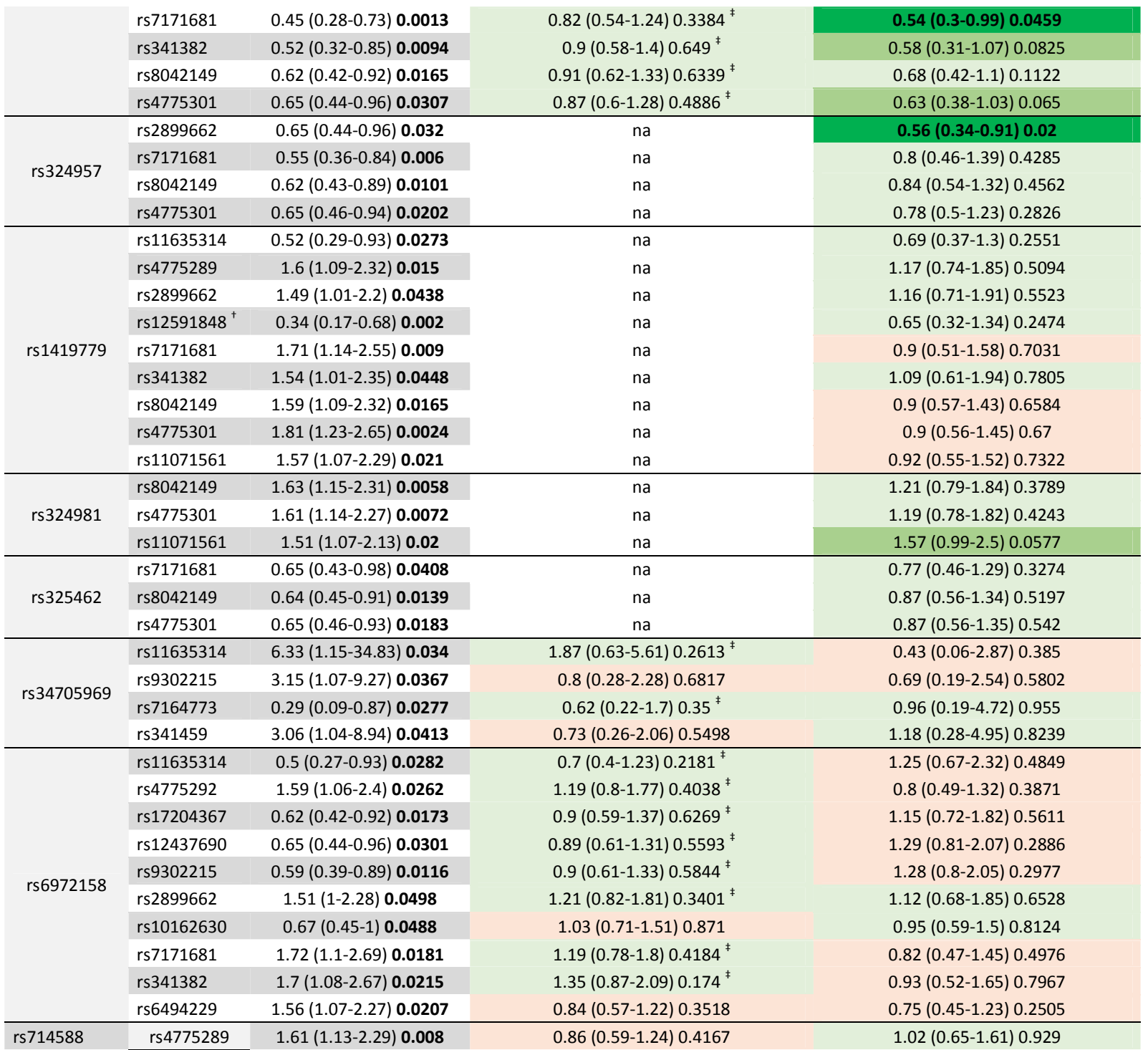




\begin{tabular}{|c|c|c|c|c|}
\hline rs 887020 & & $1.53(1.06-2.23) \mathbf{0 . 0 2 4 9}$ & $1.11(0.76-1.63) 0.5807^{\neq}$ & $0.99(0.64-1.54) 0.9759$ \\
\hline rs 740347 & & $1.67(1.02-2.73) 0.041$ & $1.65(0.97-2.8) 0.0646^{\neq}$ & $1.03(0.56-1.92) 0.9164$ \\
\hline rs1345267 & \multirow{2}{*}{ rs10162630 } & $0.63(0.44-0.91) 0.0145$ & na & $0.84(0.53-1.33) 0.4518$ \\
\hline rs323922 & & $0.66(0.45-0.95) 0.0246$ & $0.87(0.61-1.24) 0.4534^{\neq}$ & $0.74(0.48-1.14) 0.1743$ \\
\hline rs714588 & \multirow{2}{*}{ rs12591848 ${ }^{\dagger}$} & $0.53(0.29-0.98) 0.0415$ & $0.66(0.38-1.16) 0.1465^{*}$ & $0.98(0.46-2.09) 0.958$ \\
\hline rs887020 & & $0.44(0.24-0.81) 0.0089$ & $0.71(0.4-1.25) 0.2323^{\neq}$ & $0.82(0.37-1.8) 0.615$ \\
\hline rs740347 & rs7171681 & $1.81(1.06-3.09) 0.0309$ & $1.71(0.99-2.95) 0.0546^{\ddagger}$ & $0.75(0.35-1.64) 0.4749$ \\
\hline rs323922 & rs 8042149 & $1.51(1.06-2.17) 0.0234$ & $0.89(0.62-1.28) 0.5417$ & $1.22(0.79-1.88) 0.381$ \\
\hline
\end{tabular}


Supplementary Table S7. Validation of RORA*NPSR1 interaction results on nocturnal asthma in MAAS at age 16.

effect direction different than at age 11

effect direction the same as at age 11

borderline significant validation

significant validation of interaction effect on nocturnal asthma at age 16

\begin{tabular}{|c|c|c|c|}
\hline NPSR1 & RORA & $\begin{array}{l}\text { Nocturnal symptoms at age } 11 \\
\text { (MAAS) }\end{array}$ & $\begin{array}{l}\text { Nocturnal symptoms at age } 16 \\
\text { (MAAS) }\end{array}$ \\
\hline rs2609234 & rs341382 & $1.88(0.96-3.7) 0.0675$ & $1.84(0.76-4.42) 0.1747$ \\
\hline \multirow{3}{*}{ rs1379928 } & rs4775292 & $2.11(1.16-3.84) 0.0143$ & $2.34(1-5.49) 0.0505$ \\
\hline & rs12437690 & $0.53(0.3-0.93) 0.0254$ & $0.86(0.4-1.83) 0.6917$ \\
\hline & rs17204454 & $1.99(1.14-3.46) 0.0149$ & $1.87(0.87-4.01) 0.11$ \\
\hline rs324384 & rs 2899662 & $0.6(0.36-0.98) 0.0395$ & $0.55(0.28-1.1) 0.0912$ \\
\hline \multirow{4}{*}{ rs324396 } & rs2899662 & $0.48(0.28-0.82) 0.0069$ & $0.4(0.18-0.86) 0.0194$ \\
\hline & rs7171681 & $0.54(0.3-0.99) 0.0459$ & $0.48(0.2-1.12) 0.0901$ \\
\hline & rs341382 & $0.58(0.31-1.07) 0.0825$ & $0.38(0.15-0.95) 0.0384$ \\
\hline & rs4775301 & $0.63(0.38-1.03) 0.065$ & $0.83(0.4-1.71) 0.6142$ \\
\hline rs324957 & rs2899662 & $0.56(0.34-0.91) 0.02$ & $0.53(0.26-1.05) 0.0675$ \\
\hline rs324981 & rs11071561 & $1.57(0.99-2.5) 0.0577$ & $1.3(0.69-2.46) 0.4219$ \\
\hline
\end{tabular}


Supplementary Table S8. Interaction results of RORA * NPSR1-SNPs on asthma without nocturnal symptoms in MAGICS/ISAAC.

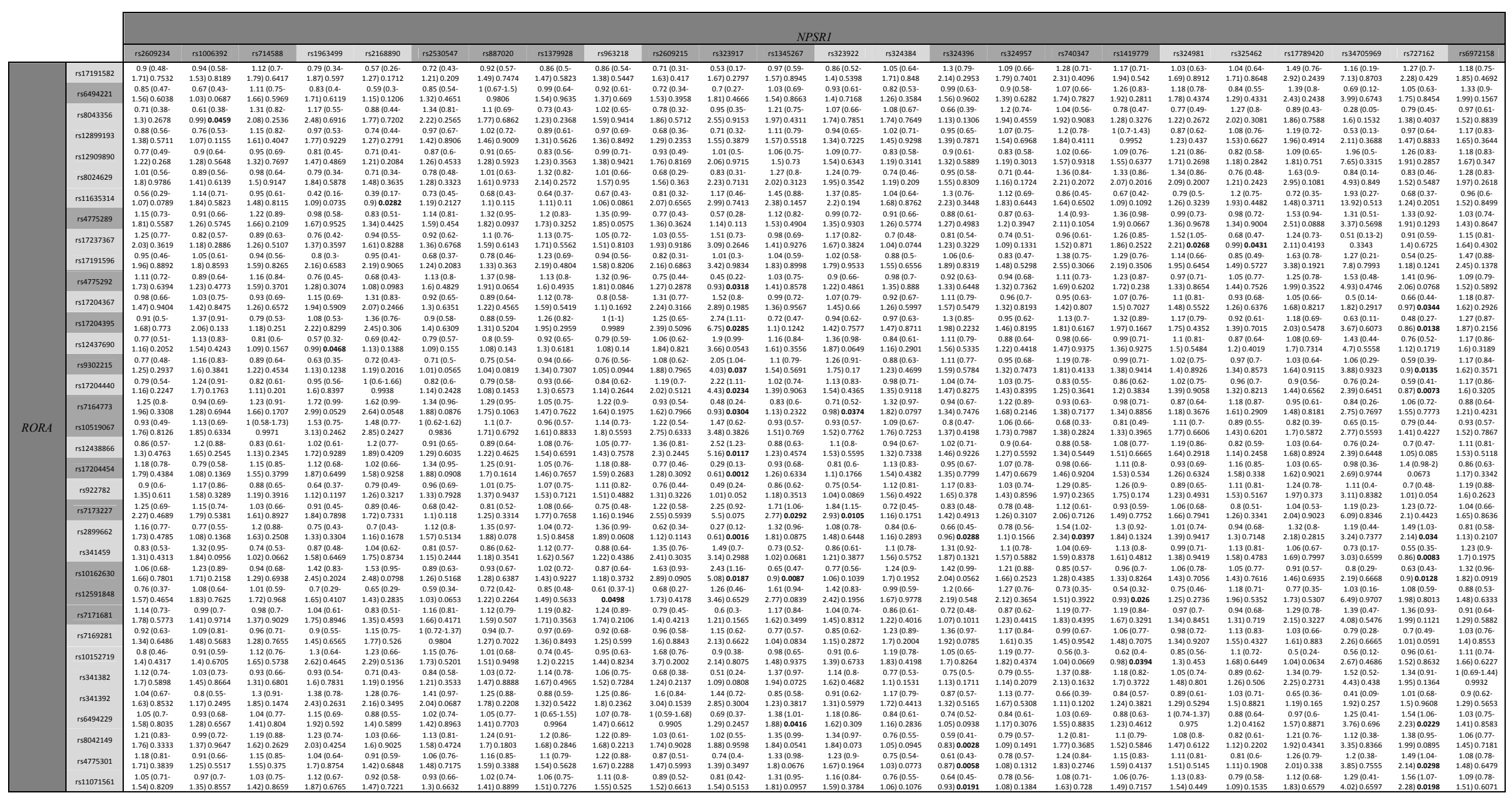


Supplementary Table S9. Complete replication results of RORA*NPSR1 interactions on asthma without nocturnal symptoms in BAMSE and MAAS.

effect direction different to MAGICS/ISAAC

effect direction the same as in MAGICS/ISAAC

borderline significant replication

significant replication of interaction on asthma without nocturnal symptoms

\begin{tabular}{|c|c|c|c|c|}
\hline NPSR1 & RORA & $\begin{array}{l}\text { asthma w/o nocturnal } \\
\text { symptoms } \\
\text { (MAGICS) }\end{array}$ & $\begin{array}{l}\text { asthma w/o nocturnal symptoms } \\
\text { (BAMSE) }\end{array}$ & $\begin{array}{l}\text { asthma w/o nocturnal symptoms } \\
\text { (MAAS) }\end{array}$ \\
\hline \multirow{9}{*}{ rs323917 } & rs4775292 & $0.45(0.22-0.93) 0.0318$ & $0.71(0.28-1.82) 0.4774$ & $0.84(0.28-2.55) 0.7638$ \\
\hline & rs17204395 & $2.74(1.11-6.75) 0.0285$ & na & $1.23(0.35-4.27) 0.7485$ \\
\hline & rs9302215 & $2.05(1.04-4.03) 0.037$ & $0.64(0.25-1.65) 0.3562$ & $1.03(0.35-3.07) 0.9555$ \\
\hline & rs17204440 & $2.22(1.11-4.43) 0.0234$ & na & $1.51(0.52-4.42) 0.4493$ \\
\hline & rs7164773 & $0.48(0.24-0.93) 0.0304$ & $0.79(0.31-1.98) 0.6152$ & $1.08(0.37-3.22) 0.8841$ \\
\hline & rs12438866 & $2.52(1.23-5.16) 0.0117$ & $2.37(1-5.61) 0.0491$ & $1.42(0.51-4) 0.5036$ \\
\hline & rs17204454 & $0.29(0.13-0.61) 0.0012$ & $0.66(0.27-1.63) 0.3654$ & $0.6(0.2-1.82) 0.3702$ \\
\hline & rs2899662 & $0.27(0.12-0.61) 0.0016$ & $1.01(0.43-2.35) 0.9871$ & $0.84(0.28-2.53) 0.751$ \\
\hline & rs10162630 & $2.43(1.16-5.08) 0.0187$ & $1.57(0.68-3.61) 0.2899$ & $1.32(0.48-3.67) 0.592$ \\
\hline \multirow{3}{*}{ rs1345267 } & rs7173227 & $1.71(1.06-2.77) 0.0292$ & na & $1.49(0.81-2.75) 0.197$ \\
\hline & rs10162630 & $0.65(0.47-0.9) \mathbf{0 . 0 0 8 7}$ & na & $0.77(0.49-1.23) 0.2743$ \\
\hline & rs6494229 & $1.38(1.01-1.88) 0.0416$ & na & $1.08(0.68-1.72) 0.749$ \\
\hline \multirow{4}{*}{ rs324396 } & rs2899662 & $0.66(0.45-0.96) 0.0288$ & $0.93(0.62-1.38) 0.7193$ & $0.69(0.41-1.15) 0.1581$ \\
\hline & rs8042149 & $0.59(0.41-0.83) 0.0028$ & $0.9(0.6-1.33) 0.586$ & $0.88(0.54-1.43) 0.6104$ \\
\hline & rs4775301 & $0.61(0.43-0.87) 0.0058$ & $0.93(0.62-1.39) 0.7257$ & $0.76(0.47-1.24) 0.277$ \\
\hline & rs11071561 & $0.64(0.45-0.93) 0.0191$ & $1.24(0.83-1.86) 0.2893$ & $0.74(0.44-1.22) 0.2379$ \\
\hline rs740347 & rs2899662 & $1.54(1.02-2.34) 0.0397$ & $1.09(0.66-1.79) 0.7492$ & $1.01(0.53-1.93) 0.9664$ \\
\hline \multirow{10}{*}{ rs727162 } & rs17204367 & $0.66(0.44-0.97) 0.0344$ & $1.08(0.67-1.73) 0.7662$ & $0.92(0.53-1.6) 0.7766$ \\
\hline & rs17204395 & $0.48(0.27-0.86) 0.0138$ & na & $0.92(0.46-1.83) 0.814$ \\
\hline & rs9302215 & $0.59(0.39-0.9) 0.0135$ & $1.02(0.65-1.6) 0.9486$ & $1.08(0.64-1.84) 0.7676$ \\
\hline & rs17204440 & $0.59(0.41-0.87) 0.0073$ & na & $0.86(0.51-1.46) 0.5808$ \\
\hline & rs2899662 & $1.49(1.03-2.14) 0.034$ & $0.9(0.56-1.43) 0.643$ & $0.9(0.52-1.54) 0.6923$ \\
\hline & rs341459 & $0.55(0.35-0.86) 0.0083$ & $1.05(0.67-1.63) 0.8467$ & $1.1(0.62-1.95) 0.7516$ \\
\hline & rs10162630 & $0.63(0.43-0.9) 0.0128$ & $1.01(0.65-1.58) 0.9579$ & $1.25(0.73-2.14) 0.4074$ \\
\hline & rs6494229 & $1.54(1.06-2.23) 0.0229$ & $1.04(0.65-1.66) 0.8829$ & $1.23(0.71-2.15) 0.4599$ \\
\hline & rs4775301 & $1.49(1.04-2.14) 0.0298$ & $0.96(0.6-1.54) 0.8702$ & $1.54(0.88-2.72) 0.1331$ \\
\hline & rs11071561 & $1.56(1.07-2.28) 0.0198$ & $0.95(0.6-1.49) 0.8132$ & $1.5(0.85-2.66) 0.1637$ \\
\hline
\end{tabular}


Supplementary Table S10. Interactions between RORA and NPSR1 on severe asthma in MAGICS/ISAAC

\begin{tabular}{|c|c|c|c|c|c|c|c|c|c|c|c|c|c|c|c|c|c|c|c|c|c|c|c|c|c|}
\hline & & \multicolumn{24}{|c|}{ NPSRI } \\
\hline & & $\mathrm{n} 2009234$ & s1006392 & s8714588 & ז19634999 & ז 22168890 & rr2530547 & r8887020 & rsL1379928 & $\mathrm{r} 9963218$ & $r_{22609215}$ & r r8323917 & ris1345267 & ${ }_{\mathrm{r} r 3232922}$ & $\mathrm{r} 3224384$ & 13324396 & r.3242457 & rs 570347 & isl1419779 & r 3324981 & $\mathrm{r} 32324462$ & rs 17789420 & $\mathrm{r} 334705969$ & $\mathrm{r} 5327162$ & ז6972158 \\
\hline \multirow{35}{*}{ RORA } & [s17191952 & $\begin{array}{c}0.09(0.2626 \\
0.722\end{array}$ & $\begin{array}{c}0.25(10.2) \\
0.1959\end{array}$ & 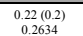 & $\begin{array}{l}0.96(0.051) \\
0.0607\end{array}$ & $\begin{array}{l}0.3(0.3) \\
0.3129\end{array}$ & $\begin{array}{c}0.29(0.21) \\
0.1722\end{array}$ & $\begin{array}{l}0.45(5.2) \\
0.026\end{array}$ & $\begin{array}{c}0.28(2.2424 \\
0.2435\end{array}$ & $\begin{array}{l}0.33(0.2) \\
0.0242\end{array}$ & $\begin{array}{c}1.09(0.39) \\
0.058\end{array}$ & $\begin{array}{c}1.31(.0 .54 \\
0.014\end{array}$ & $\begin{array}{c}-0.22(-0.18 \\
0.2367\end{array}$ & $\begin{array}{l}0.07(0.18) \\
0.09911\end{array}$ & $\begin{array}{c}-0.1(-0.19) \\
0.6188\end{array}$ & 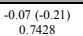 & $\begin{array}{l}-0.04(-0.2) \\
0.80 .8922\end{array}$ & $\begin{array}{c}0.22(0.23) \\
0.30505\end{array}$ & $\begin{array}{l}0.36(0.2) \\
0.0667\end{array}$ & $\begin{array}{c}-0.07(-0.2) \\
0.359\end{array}$ & $\begin{array}{l}0.18(0.2) \\
0.03523\end{array}$ & $\begin{array}{l}-0.03(-0.3) \\
0.923\end{array}$ & $\begin{array}{c}-0.27(-0.4) \\
0.508\end{array}$ & $\begin{array}{c}0.115(-0.24) \\
0.3577\end{array}$ & $\begin{array}{l}-0.14(-0.2) \\
0.50003\end{array}$ \\
\hline & ros 6494221 & $\begin{array}{c}-0.02(-0.22) \\
0.94212\end{array}$ & $\begin{array}{c}0.16(0.16) \\
0.3287\end{array}$ & $\begin{array}{l}0.09(0.17) \\
0.591\end{array}$ & $\begin{array}{c}0.35(0.42) \\
0.4015\end{array}$ & $\begin{array}{l}-0.02(-0.25) \\
0.9243\end{array}$ & $\begin{array}{c}0.13(0.18) \\
0.47708\end{array}$ & $\begin{array}{c}0.29(0.17) \\
0.08858\end{array}$ & $\begin{array}{c}0.14(0.19) \\
0.4548\end{array}$ & $\begin{array}{l}0.2(0.16)(6) \\
0.2368\end{array}$ & $\begin{array}{c}0.3(0.29) \\
0.3005\end{array}$ & $\begin{array}{c}0.66(0.43) \\
0.1244\end{array}$ & $\begin{array}{l}-0.11(-0.16) \\
0.5043\end{array}$ & $\begin{array}{l}0.05(0.16) \\
0.75\end{array}$ & $\begin{array}{l}0(-0.17) \\
0.9936\end{array}$ & $\begin{array}{c}0.06(0.19) \\
0.7635\end{array}$ & $\begin{array}{l}-0.02(-0.17) \\
0.98985\end{array}$ & $\begin{array}{c}0.32(0.21) \\
0.1291\end{array}$ & $\begin{array}{c}0.3(0.18) \\
0.092)\end{array}$ & $\begin{array}{l}-0.09(-0.17) \\
0.01223\end{array}$ & $\begin{array}{c}0.18(0.17) \\
0.2909\end{array}$ & $\begin{array}{c}0.11(0.26) \\
0.06555\end{array}$ & $\begin{array}{c}0.27(0.44) \\
0.5347\end{array}$ & $\begin{array}{c}-0.2(-0.2) \\
0.3092\end{array}$ & $\begin{array}{c}-0.18(-0.18) \\
0.3152\end{array}$ \\
\hline & ${ }_{\mathrm{r} 88043356}$ & $\begin{array}{c}0.27(0.34) \\
0.4311\end{array}$ & $\begin{array}{c}-0.4(-0.27) \\
0.1354\end{array}$ & $\begin{array}{c}0.32(0.26) \\
0.219\end{array}$ & $\begin{array}{c}0.13(0.56) \\
0.8142\end{array}$ & $\begin{array}{c}-0.11(-0.32) \\
0.7375\end{array}$ & $\begin{array}{c}0.17(0.29) \\
0.5481\end{array}$ & $\begin{array}{c}0.06(0.26) \\
0.8007\end{array}$ & $\begin{array}{l}-0.06(-0.32) \\
0.8447\end{array}$ & $\begin{array}{l}0.27(0.26) \\
0.2969\end{array}$ & $\begin{array}{r}-0.36(-0.57) \\
0.5329\end{array}$ & $\begin{array}{l}-0.72(-0.85) \\
0.4009\end{array}$ & $\begin{array}{c}0.23(0.27) \\
0.3873\end{array}$ & $\begin{array}{l}0.1(0.2) \\
0.5972\end{array}$ & $\begin{array}{l}-0.01(-0.21) \\
0.97877\end{array}$ & $\begin{array}{c}-0.3(-0.3) \\
0.3065\end{array}$ & $\begin{array}{l}-0.08(-0.27) \\
0.7565\end{array}$ & $\begin{array}{c}0.14(0.4) \\
0.7194\end{array}$ & $\begin{array}{c}0.09(0.31) \\
0.782\end{array}$ & $\begin{array}{c}0.06(0.29) \\
0.8491\end{array}$ & $\begin{array}{l}-0.05(-0.29) \\
0.852828\end{array}$ & $\begin{array}{c}0.04(0.45) \\
0.9306\end{array}$ & $\begin{array}{r}1.34(0.64) \\
0.0379\end{array}$ & $\begin{array}{c}0.62(0.32) \\
0.04966\end{array}$ & $\begin{array}{l}-0.08(-0.26) \\
0.7584\end{array}$ \\
\hline & is12899193 & $\begin{array}{c}0.18(0.2) \\
0.3588\end{array}$ & 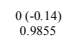 & $\begin{array}{c}0.2(0.15) \\
0.1692\end{array}$ & $\begin{array}{c}0.43(0.35) \\
0.2154\end{array}$ & $\begin{array}{l}-0.03(-0.22) \\
0.88877\end{array}$ & $\begin{array}{c}0.08(0.16) \\
0.5993\end{array}$ & $\begin{array}{c}0.25(0.15) \\
0.1026\end{array}$ & $\begin{array}{c}0.23(0.17) \\
0.1884\end{array}$ & $\begin{array}{l}0.24(0.15) \\
0.04048\end{array}$ & $\begin{array}{c}0.26(0.26) \\
0.3143\end{array}$ & $\begin{array}{l}0.51(1.37) \\
0.1652\end{array}$ & $\begin{array}{l}0.06(0.15) \\
0.6734\end{array}$ & $\begin{array}{r}0.13(0.14) \\
0.37997\end{array}$ & $\begin{array}{l}-0.15(-0.15) \\
0.32333\end{array}$ & $\begin{array}{c}-0.15(-0.17) \\
0.3873\end{array}$ & $\begin{array}{l}-0.16(-0.15) \\
0.2989\end{array}$ & $\begin{array}{c}0.35(0.2) \\
0.0752\end{array}$ & $\begin{array}{c}0.33(0.16) \\
0.0386\end{array}$ & $\begin{array}{c}0.08(0.16) \\
0.00767\end{array}$ & $\begin{array}{l}-0.03(-0.16) \\
0.861)\end{array}$ & $\begin{array}{c}0.2(0.24) \\
0.4156\end{array}$ & $\begin{array}{l}0.31(0.41) \\
0.4444\end{array}$ & $\begin{array}{l}0.04(0.19) \\
0.882\end{array}$ & $\begin{array}{l}-0.13(-0.16) \\
0.425\end{array}$ \\
\hline & Es12909890 & $\begin{array}{l}-0.02(-0.19) \\
0.91334\end{array}$ & $\begin{array}{c}0.22(.14) \\
0.11499\end{array}$ & $\begin{array}{c}-0.13(-0.14) \\
0.3763(3)\end{array}$ & $\begin{array}{c}0.31(0.31) \\
0.31966\end{array}$ & $\begin{array}{c}0.04(0.21) \\
0.836363\end{array}$ & $\begin{array}{l}-0.07(-0.15) \\
0.0222\end{array}$ & $\begin{array}{c}0.15(0.15) \\
0.325\end{array}$ & $\begin{array}{l}-.099(-0.18) \\
0.0078\end{array}$ & $\begin{array}{l}-0.07(-0.15) \\
0.06478\end{array}$ & $\begin{array}{c}0.04(0.26) \\
0.8838\end{array}$ & $\begin{array}{c}0.31(0.37) \\
0.4004\end{array}$ & $\begin{array}{l}-0.08(-0.14) \\
0.5587\end{array}$ & $\begin{array}{l}0.05(0.14) \\
0.0954\end{array}$ & $\begin{array}{l}-0.16(-0.14) \\
0.2394\end{array}$ & $\begin{array}{l}-0.01(-0.15) \\
0.964646\end{array}$ & $\begin{array}{l}-0.09(-0.14) \\
0.4966\end{array}$ & $\begin{array}{c}0.08(0.19) \\
0.6884\end{array}$ & $\begin{array}{l}0.24(0.15) \\
.0 .1085\end{array}$ & $\begin{array}{c}0.06(0.14) \\
0.06997) \\
0.60\end{array}$ & $\begin{aligned}-0.01(-0.14) \\
0.94412\end{aligned}$ & $\begin{array}{c}-0.02(-0.25) \\
0.02921\end{array}$ & $\begin{array}{l}0.44(0.39) \\
0.23363\end{array}$ & $\begin{array}{r}-0.27(-0.17) \\
0.11127\end{array}$ & $\begin{array}{c}-0.08(-0.16) \\
0.620208\end{array}$ \\
\hline & $\mathrm{r} 88024629$ & $\begin{array}{c}\frac{0.32(0.23)}{0.1655} \\
0.58\end{array}$ & $\begin{array}{c}0.13(0.17) \\
0.4634\end{array}$ & $\begin{array}{c}0.29(0.17) \\
0.095\end{array}$ & $\begin{array}{l}0.79(0.44) \\
0.072\end{array}$ & $\begin{array}{c}0.31(0.27) \\
0.2339\end{array}$ & $\begin{array}{l}\begin{array}{l}0.44(0.19) \\
0.0208\end{array} \\
0\end{array}$ & $\begin{array}{c}0.55(0.18) \\
0.0017\end{array}$ & $\begin{array}{c}0.3(0.222) \\
0.1701\end{array}$ & $\begin{array}{c}0.29(0.17) \\
0.08424\end{array}$ & $\begin{array}{c}0.83(0.35) \\
0.01844\end{array}$ & $\begin{array}{l}0.84(0.47) \\
0.0745\end{array}$ & $\begin{array}{c}-0.18(-0.16) \\
0.2574\end{array}$ & $\begin{array}{l}-0.01(-0.17) \\
0.09522\end{array}$ & $\begin{array}{l}-0.08(-0.18) \\
0.04883\end{array}$ & $\begin{array}{c}0(-0.19) \\
0.9919)\end{array}$ & $\begin{array}{l}-0.09(-0.17)(7) \\
0.59090\end{array}$ & $\begin{array}{l}0.19(0.22) \\
0.38356\end{array}$ & $\begin{array}{c}0.35(0.18) \\
0.0442) \\
0.07\end{array}$ & $\begin{array}{r}-0.02(-0.17) \\
0.000827\end{array}$ & $\begin{array}{l}0.09(1.17) \\
0.08815\end{array}$ & $\begin{array}{l}-0.01(-0.28) \\
0.96\end{array}$ & 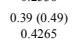 & $\begin{array}{c}-0.21(-0.21) \\
0.3247\end{array}$ & $\begin{array}{c}0.02(10.19) \\
0.09929\end{array}$ \\
\hline & r811 1635314 & $\begin{array}{r}-0.83(-0.27) \\
0.0018\end{array}$ & $\begin{array}{c}0.12(0.21) \\
0.54655\end{array}$ & $\begin{array}{r}-0.31(-0.2) \\
0.13\end{array}$ & $\begin{array}{l}-0.29(-0.44) \\
0.511\end{array}$ & $\begin{array}{r}-0.56(-0.31) \\
0.07222\end{array}$ & $\begin{array}{c}-0.29(-0.22) \\
0.1904\end{array}$ & $\begin{array}{r}-0.37(-0.21) \\
0.08080\end{array}$ & $\begin{array}{r}-0.38(-0.22) \\
0.1019) \\
0\end{array}$ & $\begin{array}{c}-0.07(-0.2) \\
0.71446\end{array}$ & $\begin{array}{l}-0.4(-.37) \\
0.2846\end{array}$ & $\begin{array}{r}-0.39(-0.56) \\
0.4821\end{array}$ & $\begin{array}{l}-0.26(-0.2) \\
0.01966)\end{array}$ & $\begin{array}{l}-0.09(-0.19) \\
0.042929\end{array}$ & $\begin{array}{c}0.19(0.2) \\
0.32822\end{array}$ & $\begin{array}{c}0.29(0.22) \\
0.1887\end{array}$ & $\begin{array}{c}0.29(0.21) \\
0.1564\end{array}$ & $\begin{array}{c}-0.02(-0.226) \\
0.94966)\end{array}$ & $\begin{array}{c}-0.07(-0.2) \\
0.7276)\end{array}$ & $\begin{array}{l}-0.14(-0.2) \\
0.49344\end{array}$ & $\begin{array}{c}0.25(0.2) \\
0.2074\end{array}$ & $\begin{array}{l}-0.09(-0.34) \\
0.794\end{array}$ & $\begin{array}{c}0.49(0.54) \\
0.30995\end{array}$ & $\begin{array}{l}-0.2(-2.24) \\
0.4228\end{array}$ & $\begin{array}{c}-0.1(-0.21) \\
0.03434 \\
0.0\end{array}$ \\
\hline & $\mathrm{rs} 4775289$ & $\begin{array}{l}0.45(0.18) \\
0.012)\end{array}$ & $\begin{array}{c}0.1(0.14) \\
0.48\end{array}$ & $\begin{array}{c}\begin{array}{c}0.4(0.14) \\
0.0037\end{array} \\
0\end{array}$ & $\begin{array}{c}0.82(0.29) \\
0.00477\end{array}$ & $\begin{array}{l}0.63(0.21) \\
0.002\end{array}$ & $\begin{array}{c}0.53(0.14) \\
0.00022\end{array}$ & $0.56(0.14) 0$ & $\begin{array}{c}0.39(0.16) \\
0.0166\end{array}$ & $\begin{array}{c}\frac{0.34(0.13)}{0.0122} \\
0\end{array}$ & $\begin{array}{c}\frac{0.59(0.24)}{0.0135} \\
0.07\end{array}$ & $\begin{array}{c}0.44(0.29) \\
0.1256\end{array}$ & $\begin{array}{c}0.03(0.13) \\
0.7886\end{array}$ & $\begin{array}{c}0.13(0.13) \\
0.3065\end{array}$ & $\begin{array}{c}-0.23(-0.13) \\
0.07722\end{array}$ & $\begin{array}{c}-0.21(-0.15) \\
0.1493\end{array}$ & $\begin{array}{c}-0.22(-0.13) \\
0.1018\end{array}$ & $\begin{array}{c}\begin{array}{c}0.5(0.18) \\
0.0066\end{array} \\
0.07\end{array}$ & $\begin{array}{c}0.43(0.14) \\
0.0015\end{array}$ & $\begin{array}{l}0(0.13) \\
0.9747\end{array}$ & $\begin{array}{l}-0.01(-0.13) \\
0.09654\end{array}$ & $\begin{array}{c}0.24(0.23) \\
0.2962(2)\end{array}$ & $\begin{array}{l}-0.33(-0.34) \\
0.332\end{array}$ & $\begin{array}{l}-0.14(-0.16) \\
0.39005\end{array}$ & $\begin{array}{c}0.18(0.14) \\
0.2266\end{array}$ \\
\hline & [1517237367 & $\begin{array}{l}-0.12(-0.22) \\
0.579\end{array}$ & $\begin{array}{l}0.12(0.16) \\
0.4784\end{array}$ & $\begin{array}{r}-0.3(-0.16) \\
0.0622\end{array}$ & $\begin{array}{c}-0.29(-0.33) \\
0.37499\end{array}$ & $\begin{array}{l}-0.42(-0.26) \\
0.1081\end{array}$ & - $\begin{array}{c}-0.29(-., 17) \\
0.08005\end{array}$ & $\begin{array}{l}-0.25(-0.16) \\
0.1233\end{array}$ & $\begin{array}{r}-0.14(-0.19) \\
0.4623\end{array}$ & $\begin{array}{c}-0.35(-0.17) \\
0.0334\end{array}$ & $\begin{array}{c}-0.42(-0.32) \\
0.1832\end{array}$ & $\begin{array}{l}-0.23(-0.39) \\
0.55\end{array}$ & $\begin{array}{l}-0.16(-0.16) \\
0.302\end{array}$ & $\begin{array}{l}-0.25(-0.15) \\
0.1097\end{array}$ & $\begin{array}{c}0.33(0.119) \\
0.0457\end{array}$ & $\begin{array}{c}0.18(0.17) \\
0.3076\end{array}$ & $\begin{array}{c}0.25(0.16) \\
0.1244\end{array}$ & $\begin{array}{l}-0.58(-0.22) \\
0.0087\end{array}$ & $\begin{array}{l}-0.46(-0.17) \\
0.0085\end{array}$ & $\begin{array}{l}-0.01(-0.16) \\
0.9536\end{array}$ & $\begin{array}{c}0.02(0.16) \\
0.914\end{array}$ & $\begin{array}{l}-0.23(-0.26) \\
0.3787\end{array}$ & $\begin{array}{c}0.55(0.54) \\
0.08081\end{array}$ & $\begin{array}{c}0.12(10.2) \\
0.5309\end{array}$ & $\begin{array}{l}-0.14(-0.17) \\
0.4128\end{array}$ \\
\hline & is17191596 & $\begin{array}{l}0.08(10.29) \\
0.78888\end{array}$ & $\begin{array}{l}0.24(4.22) \\
0.2714\end{array}$ & $\begin{array}{l}0.20202(22) \\
0.32266\end{array}$ & $\begin{array}{l}1.86(1.59) \\
0.0016)\end{array}$ & $\begin{array}{c}0.5(50.31) \\
0.08099\end{array}$ & 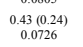 & $\begin{array}{l}0.51(10.22) \\
0.0228 \\
0.028\end{array}$ & $\begin{array}{l}0.13(3.277) \\
0.62637\end{array}$ & $\begin{array}{c}0.31(10.22) \\
0.1484\end{array}$ & $\begin{array}{c}0.9 .640 .414) \\
0.02299\end{array}$ & $\begin{array}{c}1.43(10.58) \\
0.01358\end{array}$ & $\begin{array}{l}-0.012(-0.2) \\
-0.5455\end{array}$ & $\begin{array}{l}0.15(5) .19) \\
0.43564\end{array}$ & $\begin{array}{l}-0.12(-0.21) \\
0.5471\end{array}$ & $\begin{array}{l}-0.055(-0.23) \\
0.82833\end{array}$ & $\begin{array}{l}-0.13(-0.21) \\
0.5357\end{array}$ & $\begin{array}{c}0.100070 .26) \\
0.5004 \\
0.504\end{array}$ & 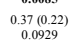 & $\begin{array}{r}-0.0 .94(-0.21) \\
0.08887\end{array}$ & $\begin{array}{l}0.088(0.22) \\
0.09612\end{array}$ & $\begin{array}{l}-0.15(-0.34) \\
0.06038\end{array}$ & $\begin{array}{l}0.733(0.55) \\
0.1857\end{array}$ & $\begin{array}{c}-0.159-0.25) \\
0.46525\end{array}$ & $\begin{aligned}-0.066(-0.25) \\
0.80074\end{aligned}$ \\
\hline & $\mathrm{r} s 4775292$ & $\begin{array}{l}0.43(10.18) \\
0.01133)\end{array}$ & $\begin{array}{c}0.08(.14) \\
0.55522)\end{array}$ & $\begin{array}{l}0.29(1.044) \\
0.03919\end{array}$ & $\begin{array}{l}0.38(.0 .31) \\
0.03350\end{array}$ & $\begin{array}{l}0.28(1022) \\
0.71212\end{array}$ & $\begin{array}{l}0.266(0.14) \\
0.70736\end{array}$ & $\begin{array}{l}0.36(1.14) \\
0.009595\end{array}$ & $\begin{array}{l}0.34(1.16) \\
0.030303\end{array}$ & $\begin{array}{c}0.13(10.13) \\
0.3244)\end{array}$ & $\begin{array}{c}0.22(2.024) \\
0.354\end{array}$ & $\begin{array}{c}0.15(.0 .11) \\
0.0247\end{array}$ & $\begin{array}{c}-0.05(-0.13) \\
0.6883\end{array}$ & $\begin{aligned}-0.03(-0.13) \\
0.973\end{aligned}$ & $\begin{array}{c}0.08(-0.13) \\
0.5488\end{array}$ & $\begin{array}{c}-0.066(-0.15) \\
0.9943\end{array}$ & $\begin{array}{c}-0.066-0.1 .13) \\
0.4985\end{array}$ & $\begin{array}{c}0.28(10.17) \\
0.1032\end{array}$ & $\begin{array}{c}0.26(0.14) \\
0.5991\end{array}$ & $\begin{aligned}-0.04(-0.13) \\
0.344\end{aligned}$ & $\begin{array}{l}0.03(0.13) \\
0.8328\end{array}$ & $\begin{array}{c}0.27(0.22) \\
0.2222)\end{array}$ & 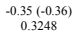 & $\begin{aligned}-0.17(-0.116) \\
0.3125\end{aligned}$ & $\begin{array}{c}0.222(0.15) \\
0.1369\end{array}$ \\
\hline & is172004367 & $\begin{array}{l}-0.33(-0.18) \\
0.06993\end{array}$ & $\begin{array}{l}-0.13(-0.14) \\
0.3623\end{array}$ & $\begin{array}{c}0.06(0.14) \\
0.5662\end{array}$ & $\begin{array}{c}-0.07(-0.31) \\
0.8311\end{array}$ & $\begin{array}{c}0.14(0.2) \\
0.4784\end{array}$ & $\begin{array}{c}0.11(0.15) \\
0.4506\end{array}$ & $\begin{array}{c}-0.01(-0.15) \\
0.96022)\end{array}$ & $\begin{array}{l}-.111(-0.16) \\
0.4944\end{array}$ & $\begin{array}{c}0.18(0.14) \\
0.1899\end{array}$ & $\begin{array}{c}0.26(0.25) \\
0.308\end{array}$ & $\begin{array}{c}0.5(0.31) \\
0.1072\end{array}$ & $\begin{array}{c}-0.12(-0.13) \\
0.3572)\end{array}$ & $\begin{array}{c}0.01(0.13) \\
0.9207\end{array}$ & $\begin{array}{c}0.12(0.13) \\
0.3531\end{array}$ & $\begin{array}{c}0.1(0.15) \\
0.5097\end{array}$ & $\begin{array}{c}0.13(0.13) \\
0.3388\end{array}$ & $\begin{array}{c}-0.18(-0.17) \\
0.3102\end{array}$ & $\begin{array}{c}-0.07(-0.14) \\
0.003636\end{array}$ & $\begin{array}{c}-0.09(-0.13) \\
0.52411\end{array}$ & $\begin{array}{c}0.12(0.13) \\
0.3717\end{array}$ & $\begin{array}{c}-0.28(-0.22) \\
0.20255\end{array}$ & $\begin{array}{c}-0.1(-0.39) \\
0.7932\end{array}$ & $\begin{array}{c}0.16(0.16) \\
0.3377\end{array}$ & $\begin{array}{c}-0.17(-0.14) \\
0.2233\end{array}$ \\
\hline & ist 7204395 & $\begin{array}{c}-0.04(-0.21) \\
0.8367\end{array}$ & $\begin{array}{c}0.02(0.18) \\
0.91\end{array}$ & $\begin{array}{c}0.14(0.17) \\
0.4103\end{array}$ & $\begin{array}{c}0.54(0.38) \\
0.1559\end{array}$ & $\begin{array}{l}0.48(0.24) \\
0.04868\end{array}$ & $\begin{array}{c}0.2(0.18) \\
0.2634\end{array}$ & $\begin{array}{l}0.19(0.17) \\
0.2555\end{array}$ & $\begin{array}{c}0.16(0.2) \\
0.43222\end{array}$ & $\begin{array}{c}0.16(0.17) \\
0.3262\end{array}$ & $\begin{array}{c}0.78(0.31) \\
0.0123\end{array}$ & $\begin{array}{l}0.6(0.4) \\
0.1349\end{array}$ & $\begin{array}{l}-0.01(-0.17) \\
0.94418\end{array}$ & $\begin{array}{c}0.1(0.16) \\
0.542\end{array}$ & $\begin{array}{l}-0.09(-0.17) \\
0.6116\end{array}$ & $\begin{array}{l}-0.16(-0.19) \\
0.403\end{array}$ & $\begin{array}{l}-0.11(-0.17) \\
0.5355\end{array}$ & $\begin{array}{c}0.05(0.22) \\
0.8325\end{array}$ & $\begin{array}{c}0.130 .13(17) \\
0.4614\end{array}$ & $\begin{array}{l}0.06(1.17) \\
0.717868\end{array}$ & $\begin{array}{r}-0.08(-0.17) \\
0.62014\end{array}$ & $\begin{array}{l}0.0269) \\
0.0881 \\
0.888\end{array}$ & $\begin{array}{l}0.22(10.5) \\
0.08824\end{array}$ & $\begin{array}{l}0.099(0.21) \\
0.06621\end{array}$ & $\begin{array}{l}-0.12(-0.17) \\
0.503\end{array}$ \\
\hline & is124247690 & $\begin{array}{r}-0.51(-0.118) \\
0.0039\end{array}$ & $\begin{array}{c}0.1(0.14) \\
0.4792)\end{array}$ & $\begin{array}{l}-0.23(-0.13) \\
0.0857\end{array}$ & $\begin{array}{c}-0.09(-0.29) \\
0.74729\end{array}$ & $\begin{array}{c}-0.1(-0.2) \\
0.62266 \\
0.620\end{array}$ & 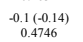 & $\begin{array}{r}-0.15(-0.14) \\
0.2851\end{array}$ & $\begin{array}{c}-0.26(-0.15) \\
0.08826\end{array}$ & $\begin{array}{c}-0.04(-0.13) \\
0.75838\end{array}$ & $\begin{array}{c}-0.08(-0.25) \\
0.72313\end{array}$ & $\begin{array}{l}-0.1(1 .-0.31) \\
0.73655 \\
0.75\end{array}$ & $\begin{array}{l}-0.03(-0.13) \\
0.000522\end{array}$ & $\begin{array}{c}0.04(0.13) \\
0.77646\end{array}$ & $\begin{array}{l}0.12(20.13) \\
0.343\end{array}$ & $\begin{array}{l}0.08(0.15) \\
0.01997\end{array}$ & $\begin{array}{c}0.09(0.13) \\
0.048464\end{array}$ & $\begin{array}{l}0.02(0.18) \\
0.0993636\end{array}$ & $\begin{array}{l}-0.04(-0.14) \\
0.782\end{array}$ & $\begin{array}{c}0.01(0.13) \\
0.06224\end{array}$ & $\begin{array}{l}0.08(0.13) \\
0.0513\end{array}$ & $\begin{array}{c}0.02(0.21) \\
0.93228\end{array}$ & $\begin{array}{l}0.49(0.37) \\
0.1857\end{array}$ & $\begin{array}{l}-0.01(-0.17) \\
0.931\end{array}$ & $\begin{array}{r}-0.06-0.1 .14) \\
0.08812\end{array}$ \\
\hline & ${ }_{\mathrm{r} 99302215}$ & $\begin{array}{c}-0.32(-0.18) \\
0.0727\end{array}$ & $\begin{array}{c}0.07(0.14) \\
0.6108\end{array}$ & $\begin{array}{c}-0.07(-0.14) \\
0.5844\end{array}$ & $\begin{array}{c}0.21(0.32) \\
0.5012\end{array}$ & $\begin{array}{c}0.17(10.2) \\
0.4056\end{array}$ & $\begin{array}{c}0.03(0.14) \\
0.8263\end{array}$ & $\begin{array}{c}-0.06(-0.14) \\
0.56588\end{array}$ & $\begin{array}{c}-0.04(-0.15) \\
0.7972)\end{array}$ & $\begin{array}{c}0.13(0.14) \\
0.3284\end{array}$ & $\begin{array}{c}0.31(0.23) \\
0.1814\end{array}$ & $\begin{array}{c}\begin{array}{c}0.34(0.3) \\
0.2551\end{array} \\
0\end{array}$ & $\begin{array}{c}-0.07(-0.13) \\
0.57228\end{array}$ & $\begin{array}{c}0.06(0.13) \\
0.036\end{array}$ & $\begin{array}{c}0.08(0.13) \\
0.564\end{array}$ & $\begin{array}{c}0.02(0.15) \\
0.8735\end{array}$ & $\begin{array}{c}0.05(0.13) \\
0.6891\end{array}$ & $\begin{array}{c}0.05(0.18) \\
0.7698\end{array}$ & $\begin{array}{l}0.080 .1414) \\
0.57765\end{array}$ & $\begin{array}{c}0(0.0 .13) \\
0.902828\end{array}$ & $\begin{array}{l}0.05(0.13) \\
0.705\end{array}$ & $\begin{array}{l}0.030 .222(12) \\
0.9769)\end{array}$ & $\begin{array}{c}0.2550 .36) \\
0.4938\end{array}$ & $\begin{array}{l}-0.01(-1.17) \\
0.9519\end{array}$ & $\begin{array}{l}-0.12(-1.14) \\
0.3772) \\
0.372\end{array}$ \\
\hline & is172004440 & $\begin{array}{l}-0.15(-0.17) \\
0.37866\end{array}$ & $\begin{array}{c}0.04(0.13) \\
0.7774\end{array}$ & $\begin{array}{l}-0.09(-0.13) \\
0.4756\end{array}$ & $\begin{array}{l}-0.066(-0.24) \\
0.08083\end{array}$ & $\begin{array}{l}-0.05(-0.19) \\
0.0063(1)\end{array}$ & $\begin{array}{l}-0.03(-0.14) \\
0.055\end{array}$ & $\begin{array}{c}-0.12(-0.13) \\
0.3733\end{array}$ & $\begin{array}{l}-0.02(-0.15) \\
0.8715\end{array}$ & $\begin{array}{l}0.07(0.13) \\
0.6162\end{array}$ & $\begin{array}{c}0.22(0.22) \\
0.32322\end{array}$ & $\begin{array}{c}0.240 .2727) \\
0.3752\end{array}$ & $\begin{array}{l}-0.06(-0.12) \\
0.6445\end{array}$ & $\begin{array}{c}0.04(0.12) \\
0.7595\end{array}$ & $\begin{array}{l}0.05(0.12) \\
0.676\end{array}$ & $\begin{array}{c}0.03(0.14) \\
0.85899\end{array}$ & $\begin{array}{c}0.04(0.12) \\
0.7434\end{array}$ & $\begin{array}{c}-0.1(-0.17) \\
0.5595\end{array}$ & $\begin{array}{c}-0.02(-0.113) \\
0.89393\end{array}$ & $\begin{array}{c}0.05(0.13) \\
0.7006\end{array}$ & $\begin{array}{l}0(0.13) \\
0.9996\end{array}$ & $\begin{array}{l}-0.16(-0.21) \\
0.4775\end{array}$ & $\begin{array}{l}0.14(1.34) \\
0.0861)\end{array}$ & $\begin{array}{l}-0.01(-0.16) \\
0.93838\end{array}$ & $\begin{array}{l}-0.35(-0.14) \\
0.0126\end{array}$ \\
\hline & rs:164773 & $\begin{array}{l}-0.06(-0.17) \\
0.733\end{array}$ & $\begin{array}{c}0.14(0.13) \\
0.2805\end{array}$ & $\begin{array}{l}-0.09(-0.13) \\
0.4922\end{array}$ & $\begin{array}{c}0.0110 .29) \\
0.976464\end{array}$ & $\begin{array}{l}-0.01(-0.2) \\
0.06773\end{array}$ & $\begin{array}{c}-0.04(-0.14) \\
0.7678\end{array}$ & $\begin{array}{c}0.04(0.13) \\
0.7836\end{array}$ & $\begin{array}{c}0.07(0.15) \\
0.6274\end{array}$ & $\begin{array}{c}0.08(0.13) \\
0.5475\end{array}$ & $\begin{array}{c}0.11(0.24) \\
0.6529\end{array}$ & $\begin{array}{c}0.17(0.3) \\
0.5758\end{array}$ & $\begin{array}{c}-0.1(-0.12) \\
0.0058\end{array}$ & $\begin{array}{l}-0.04(-0.13) \\
0.7691\end{array}$ & $\begin{array}{l}0.08(0.13) \\
0.5413\end{array}$ & $\begin{array}{c}0.09(0.15) \\
0.53351\end{array}$ & $\begin{array}{l}0.05(0.13) \\
0.6599\end{array}$ & $\begin{array}{c}0.07(0.18) \\
0.6725\end{array}$ & $\begin{array}{c}0.07(0.14) \\
0.5815\end{array}$ & $\begin{array}{l}-0.02(-0.13) \\
0.8562(3)\end{array}$ & $\begin{array}{c}0.08(0.13) \\
0.5661\end{array}$ & $\begin{array}{c}0.05(0.21) \\
0.8148\end{array}$ & $\begin{array}{c}0.6(0.38) \\
0.1133\end{array}$ & $\begin{array}{l}-0.21(-0.17) \\
0.2193\end{array}$ & $\begin{array}{c}-0.05(-0.13) \\
0.7082\end{array}$ \\
\hline & [s1051 19067 & $\begin{array}{c}0.22(0.277) \\
0.4296\end{array}$ & $\begin{array}{c}-0.1(-0.21) \\
0.0155\end{array}$ & $\begin{array}{l}-0.1(-0.2) \\
0.6238\end{array}$ & $\begin{array}{r}0.11(0.44) \\
0.8077\end{array}$ & $\begin{array}{l}-0.34(-0.29) \\
0.2415\end{array}$ & $\begin{array}{l}-0.12(-0.23) \\
0.01222\end{array}$ & $\begin{array}{l}-0.09(-0.21) \\
0.67711\end{array}$ & $\begin{array}{l}-0.05(-0.25) \\
0.8318\end{array}$ & $\begin{array}{l}-0.14(-0.2) \\
0.5024\end{array}$ & $\begin{array}{l}-0.11(-0.38) \\
0.7736\end{array}$ & $\begin{array}{l}-0.49(-0.47) \\
0.2945\end{array}$ & $\begin{array}{l}0.1(10.2) \\
0.6102\end{array}$ & $\begin{array}{c}0.04(0.2) \\
0.8363\end{array}$ & $\begin{array}{l}-0.07(-0.21) \\
0.7437\end{array}$ & $\begin{array}{l}-0.13(-0.23) \\
0.5819\end{array}$ & $\begin{array}{l}-0.06(-0.21) \\
0.79099\end{array}$ & $\begin{array}{l}-0.28(-0.28) \\
0.3116\end{array}$ & $\begin{array}{l}-0.24(-0.21) \\
0.2515\end{array}$ & $\begin{array}{l}0.16(10.22) \\
0.4005\end{array}$ & $\begin{array}{l}-0.18(-0.22) \\
0.4158\end{array}$ & $\begin{array}{l}-0.2(-0.31) \\
0.52201\end{array}$ & $\begin{array}{l}-0.14(-0.58) \\
0.8006\end{array}$ & $\begin{array}{c}0.13(0.24) \\
0.575\end{array}$ & $\begin{array}{l}-0.37(-0.21) \\
0.0718\end{array}$ \\
\hline & Is12438866 & $\begin{array}{c}-0.12(-0.17) \\
0.4727\end{array}$ & $\begin{array}{c}-0.03(-0.14) \\
0.82889\end{array}$ & $\begin{array}{c}-0.18(-0.13) \\
0.1896\end{array}$ & $\begin{array}{c}-0.19(-0.25) \\
0.4305\end{array}$ & $\begin{array}{c}-0.23(-0.19) \\
0.2288\end{array}$ & $\begin{array}{c}-0.26(-0.15) \\
0.07311\end{array}$ & $\begin{array}{c}-0.19(-0.13) \\
0.1396\end{array}$ & $\begin{array}{c}-0.14(-0.16) \\
0.3683\end{array}$ & $\begin{array}{c}-0.13(-0.13) \\
0.3139\end{array}$ & $\begin{array}{l}-0.15(-0.24) \\
0.538\end{array}$ & $\begin{array}{l}-0.24(-0.28) \\
0.3973\end{array}$ & $\begin{array}{l}0.06(0.13) \\
0.6359\end{array}$ & $\begin{array}{l}0.03(0.13) \\
0.8145\end{array}$ & $\begin{array}{l}-0.06(-0.13) \\
0.052\end{array}$ & $\begin{array}{l}-0.08(-0.15) \\
0.5631\end{array}$ & $\begin{array}{l}-0.07(-0.13) \\
0.5993\end{array}$ & $\begin{array}{c}-0.12(-0.17) \\
0.4779\end{array}$ & $\begin{array}{l}-0.1(-.1 .14) \\
0.4885\end{array}$ & $\begin{array}{c}0.17(0.13) \\
0.2043\end{array}$ & $\begin{array}{l}-0.12(-0.13) \\
0.3334\end{array}$ & $\begin{array}{l}-0.066(-0.22) \\
0.7728\end{array}$ & $\begin{array}{c}0.65(0.4) \\
0.1036\end{array}$ & $\begin{array}{l}0.04(0.17) \\
0.8314\end{array}$ & $\begin{array}{r}-0.28(-0.14) \\
0.0493\end{array}$ \\
\hline & is17200454 & $\begin{array}{c}0.22(0.17) \\
0.1918\end{array}$ & $\begin{array}{c}-0.07(-0.13) \\
0.59665)\end{array}$ & 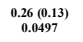 & $\begin{array}{c}0.12(10.29) \\
0.68966\end{array}$ & $\begin{array}{c}0.28(0.19) \\
0.1377\end{array}$ & $\begin{array}{l}0.14(0.14) \\
0.2899\end{array}$ & $\begin{array}{c}0.15(0.13) \\
0.2613\end{array}$ & $\begin{array}{c}0.11(0.15) \\
0.4791\end{array}$ & $\begin{array}{c}0.05(0.13) \\
0.6724\end{array}$ & $\begin{array}{c}0.11(0.23) \\
0.0398\end{array}$ & $\begin{array}{c}0.3 .30299) \\
0.302\end{array}$ & $\begin{array}{l}-0.02(-0.13) \\
0.8765(3)\end{array}$ & $\begin{array}{l}-0.05(-0.12) \\
0.7125\end{array}$ & $\begin{array}{l}-0.04(-0.13) \\
0.7461\end{array}$ & $\begin{array}{c}0.02(0.14) \\
0.8998\end{array}$ & $\begin{array}{l}-0.01(-0.13) \\
0.93585\end{array}$ & $\begin{array}{c}0.09(0.17) \\
0.5883\end{array}$ & 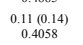 & $\begin{array}{c}-0.088(-0.13) \\
0.51156\end{array}$ & $\begin{array}{l}0.032(1.13) \\
0.08098\end{array}$ & $\begin{array}{l}0.12120 .217 \\
0.59907\end{array}$ & 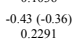 & $\begin{array}{c}-0.038(-0.16) \\
0.844646\end{array}$ & $\begin{array}{l}0.28(0.14) \\
0.04314\end{array}$ \\
\hline & ${ }_{\mathrm{r} 9922782}$ & $\begin{array}{c}-0.01(-0.17) \\
0.93727\end{array}$ & $\begin{array}{l}0.07(0.13) \\
0.6212\end{array}$ & $\begin{array}{c}0.14(0.13) \\
0.2835\end{array}$ & $\begin{array}{c}0.51(0.31) \\
0.104\end{array}$ & $\begin{array}{l}0.3(0.2) \\
0.1331 \\
0.131\end{array}$ & $\begin{array}{c}0.12(2.14) \\
0.385656\end{array}$ & $\begin{array}{c}0.13(10.14) \\
0.34787\end{array}$ & $\begin{array}{c}0.16(0.16) \\
0.321212\end{array}$ & $\begin{array}{c}0.08(0.13) \\
0.551212\end{array}$ & $\begin{array}{c}0.32(20.25) \\
0.2031\end{array}$ & $\begin{array}{c}0.190 .34) \\
0.57755\end{array}$ & $\begin{array}{c}-0.04(-0.13) \\
0.7578\end{array}$ & $\begin{array}{l}0.10 .13) \\
0.9927 \\
0.92\end{array}$ & $\begin{array}{r}-0.08(-0.13) \\
0.52727\end{array}$ & $\begin{array}{l}-0.09(-0.14) \\
0.52215\end{array}$ & $\begin{array}{l}-0.077(-0.13) \\
0.08802\end{array}$ & $\begin{array}{c}0.1990 .18) \\
0.2766\end{array}$ & 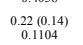 & 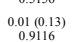 & 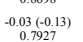 & 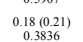 & $\begin{array}{c}-0.21193 \\
-0.11-0.33) \\
0.739\end{array}$ & 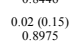 & $\begin{array}{c}0.0691 \\
0.06(1.13) \\
0.6261\end{array}$ \\
\hline & [rs 7173227 & $\begin{array}{c}-0.23(-0.26) \\
0.38303\end{array}$ & $\begin{array}{c}-0.066(-0.2) \\
0.77995\end{array}$ & $\begin{array}{c}-0.29(-0.19) \\
0.1212\end{array}$ & $\begin{array}{c}-0.5(-.0 .33) \\
0.13\end{array}$ & $\begin{array}{c}-0.34(-0.27) \\
0.2069\end{array}$ & $\begin{array}{l}-0.033(-0.2) \\
0.8917\end{array}$ & $\begin{array}{l}-0.13(-0.19) \\
0.4737\end{array}$ & $\begin{array}{c}-0.13(-0.24) \\
0.59622)\end{array}$ & $\begin{array}{l}-0.03(-0.2) \\
0.87\end{array}$ & $\begin{array}{l}-0.41(-0.33) \\
0.2435\end{array}$ & $\begin{array}{l}-0.37(-0.45) \\
0.4116)\end{array}$ & $\begin{array}{c}0.064(10.19) \\
0.8413\end{array}$ & $\begin{array}{c}0.01(1.18) \\
0.9731\end{array}$ & $\begin{array}{l}0.14(12.19) \\
0.4468\end{array}$ & $\begin{array}{c}0.05(0.2) \\
0.8145\end{array}$ & $\begin{array}{l}0.0606(19) \\
0.7609\end{array}$ & $\begin{array}{l}-0.13(-0.027) \\
0.01989\end{array}$ & $\begin{array}{l}-0.1919(-0.2) \\
0.3933\end{array}$ & 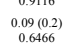 & $\begin{array}{l}0.0 .9427 \\
0.040 .27 \\
0.838\end{array}$ & 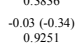 & 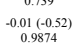 & 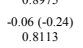 & 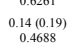 \\
\hline & rr28896662 & $\begin{array}{l}0.05(0.18) \\
0.7579\end{array}$ & $\begin{array}{l}0.05(0.14) \\
0.7507\end{array}$ & $\begin{array}{l}0.09(0.14) \\
0.499\end{array}$ & $\begin{array}{c}0.3(0.31) \\
0.3325\end{array}$ & $\begin{array}{c}0.17(0.2) \\
0.9968\end{array}$ & $\begin{array}{c}0.1(0.14) \\
0.4646\end{array}$ & $\begin{array}{l}0.05(0.13) \\
0.7177\end{array}$ & $\begin{array}{c}0.03(0.16) \\
0.8713\end{array}$ & $\begin{array}{l}-0.01(-0.14) \\
0.940404\end{array}$ & $\begin{array}{c}0.17(0.25) \\
0.4843\end{array}$ & $\begin{array}{c}0.24(0.32) \\
0.4518\end{array}$ & $\begin{array}{c}0.08(0.13) \\
0.5571\end{array}$ & $\begin{array}{l}0.07(0.13) \\
0.568\end{array}$ & $\begin{array}{c}-0.16(-0.13) \\
0.2146\end{array}$ & $\begin{array}{l}-0.09(-0.15) \\
0.5639\end{array}$ & $\begin{array}{l}-0.11(1-0.13) \\
0.4251\end{array}$ & $\begin{array}{c}0.21(0.18) \\
0.2242\end{array}$ & $\begin{array}{c}0.14(1.14) \\
0.3005\end{array}$ & $\begin{array}{l}-0.03(-0.14) \\
0.02511\end{array}$ & $\begin{array}{l}-0.02(-0.13) \\
0.098086\end{array}$ & $\begin{array}{c}0.160 .2024) \\
0.50353\end{array}$ & $\begin{array}{l}-0.54(-0.35) \\
0.129\end{array}$ & $\begin{array}{l}-0.15(-0.16) \\
0.3666\end{array}$ & $\begin{array}{l}0.3(0.14) \\
0.0382\end{array}$ \\
\hline & r 3341459 & $\begin{array}{l}0.147(18.18) \\
0.4477\end{array}$ & $\begin{array}{l}-0.05(-0.15) \\
0.7308\end{array}$ & $\begin{array}{c}0.7(2.14) \\
0.1546\end{array}$ & $\begin{array}{l}0.060(0.33) \\
0.85999)\end{array}$ & $\begin{array}{c}0.2(10.21) \\
0.32288\end{array}$ & $\begin{array}{l}0.040(10.15) \\
0.75868\end{array}$ & $\begin{array}{l}0.14(1.14) \\
0.3291\end{array}$ & $\begin{array}{l}0.13(3.17) \\
0.4318\end{array}$ & $\begin{array}{l}0.077(14) \\
0.611\end{array}$ & $\begin{array}{l}-0.033(-0.226) \\
0.9167\end{array}$ & $\begin{array}{c}0.1370 .37) \\
0.7301\end{array}$ & $\begin{array}{l}-0.099(-1.14) \\
0.0051\end{array}$ & $\begin{array}{l}-0.070(-1.14) \\
0.0 .92929\end{array}$ & $\begin{array}{l}0.04(40.14) \\
0.7554\end{array}$ & $\begin{array}{l}0.01(10.15) \\
0.9575\end{array}$ & $\begin{array}{l}0.02(20.14) \\
0.8863(4)\end{array}$ & $\begin{array}{l}0.01218 \\
0.018 \\
0.9971\end{array}$ & $\begin{array}{l}0.120 .10 .15) \\
0.404\end{array}$ & $\begin{array}{l}0.01014 \\
0.014) \\
0.992828\end{array}$ & $\begin{array}{l}-0.032(-0.14) \\
0.09045\end{array}$ & $\begin{array}{l}0.099(0.22) \\
0.08989\end{array}$ & $\begin{array}{c}0.099(3) .35) \\
0.79655\end{array}$ & 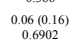 & $\begin{array}{l}-0.150 .1-0.14) \\
0.2957 \\
0.2957\end{array}$ \\
\hline & $\mathrm{r}=10102630$ & $\begin{array}{l}0.04(1.017) \\
0.08047\end{array}$ & $\begin{array}{l}-0.05(-0.14) \\
0.7288\end{array}$ & $\begin{array}{l}0.08(0.014) \\
0.57703)\end{array}$ & $\begin{array}{l}0.07(0.929) \\
0.8066\end{array}$ & $\begin{array}{l}0.03(1.19) \\
0.08887)\end{array}$ & $\begin{array}{l}-0.09(-0.14) \\
0.52014)\end{array}$ & $\begin{array}{l}0(-0.13) \\
0.9942)\end{array}$ & $\begin{array}{c}0.01(1.016) \\
0.95421\end{array}$ & $\begin{aligned} 0.02(-0.1-13) \\
0.00050\end{aligned}$ & $\begin{aligned}-0.02(-0.24) \\
0.9484\end{aligned}$ & 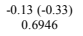 & $\begin{aligned}-0.03(-0.13) \\
0.8\end{aligned}$ & $\begin{array}{l}0.0(1.13) \\
0.98588\end{array}$ & $\begin{array}{c}0.06(0.013) \\
0.6474)\end{array}$ & $\begin{array}{c}0.03(0.015) \\
0.84883\end{array}$ & $\begin{array}{l}0.06(0.013) \\
0.65959)\end{array}$ & $\begin{aligned}-0.13(-0.17) \\
0.44327\end{aligned}$ & $\begin{array}{l}-0.11(-.0 .14) \\
0.04037\end{array}$ & $\begin{array}{l}0.0 .13) \\
0.9135\end{array}$ & $\begin{array}{l}0 .(-0.13) \\
0.970101\end{array}$ & $\begin{array}{l}-0.12(1-0.22) \\
0.88337\end{array}$ & $\begin{array}{l}0.04 .01039) \\
0.919\end{array}$ & $\begin{array}{l}0.23(1.16) \\
0.14216\end{array}$ & $\begin{aligned}-0.37(-0.14) \\
0.0073\end{aligned}$ \\
\hline & is12591848 & $\begin{array}{l}-0.09(-0.31) \\
0.07774\end{array}$ & $\begin{array}{c}0.39(0.23) \\
0.0944)\end{array}$ & $\begin{array}{c}-0.29(-0.22) \\
0.1857\end{array}$ & $\begin{array}{c}-0.3(-0.47) \\
-0.5215\end{array}$ & $\begin{array}{c}-0.11(-0.36) \\
0.7508\end{array}$ & $\begin{array}{c}0.11(10.25) \\
0.6497\end{array}$ & $\begin{array}{l}-0.21(-0.23) \\
0.3561\end{array}$ & $\begin{array}{c}0.16(0.27) \\
0.56633\end{array}$ & $\begin{array}{c}0.22(2.24) \\
0.3548\end{array}$ & $\begin{array}{c}0.41(0.42) \\
0.3271\end{array}$ & $\begin{array}{c}0.01(0.6) \\
0.3153\end{array}$ & $\begin{array}{l}-0.2(-0.21) \\
0.3526\end{array}$ & $\begin{array}{l}-0.12(-0.22) \\
0.5926\end{array}$ & $\begin{array}{c}0.35(0.23) \\
0.1245\end{array}$ & $\begin{array}{l}0.28(0.25) \\
0.26675\end{array}$ & $\begin{array}{c}0.32(0.22) \\
0.15222\end{array}$ & $\begin{array}{l}-0.29(-0.32) \\
0.3721\end{array}$ & $\begin{array}{l}-0.27(-0.26) \\
0.3017\end{array}$ & $\begin{array}{r}-0.28(-0.24) \\
0.2534\end{array}$ & $\begin{array}{l}0.33(0.25) \\
0.1856\end{array}$ & $\begin{array}{l}-0.25(-0.39) \\
0.522\end{array}$ & $\begin{array}{c}0.58(0.52) \\
0.2603\end{array}$ & $\begin{array}{l}0(0.26) \\
0.99666\end{array}$ & $\begin{array}{c}-0.07(-0.22) \\
0.7448\end{array}$ \\
\hline & rs:1717681 & $\begin{array}{c}0.22(0.18) \\
0.2246\end{array}$ & $\begin{array}{l}-0.077(-0.15) \\
0.6474\end{array}$ & $\begin{array}{l}0.24(0.15) \\
0.114\end{array}$ & $\begin{array}{c}0.29(0.32) \\
0.3583\end{array}$ & $\begin{array}{c}0.25(0.21) \\
0.2497\end{array}$ & $\begin{array}{c}0.23(0.15) \\
0.1198\end{array}$ & $\begin{array}{c}0.2(0.14) \\
0.1577\end{array}$ & $\begin{array}{c}0.2(0.17) \\
0.2406\end{array}$ & $\begin{array}{c}0.05(0.14) \\
0.7067\end{array}$ & $\begin{array}{l}0.09(0.25) \\
0.7142)\end{array}$ & $\begin{array}{c}0.22(0.32) \\
0.5016\end{array}$ & $\begin{array}{c}0.1(1.144) \\
0.4785\end{array}$ & $\begin{array}{l}0.08(0.14) \\
0.55966\end{array}$ & $\begin{array}{l}-0.26(-0.14) \\
0.064\end{array}$ & $\begin{array}{l}-0.29(-0.16) \\
0.068\end{array}$ & $\begin{array}{l}-0.23(-0.14) \\
0.0917)\end{array}$ & $\begin{array}{c}0.2(0.18) \\
0.2711\end{array}$ & $\begin{array}{c}0.24(0.14) \\
0.0984\end{array}$ & $\begin{array}{l}0.07(0.14) \\
0.611212\end{array}$ & $\begin{array}{l}-0.13(-0.14) \\
0.3424\end{array}$ & $\begin{array}{c}0.15(10.24) \\
0.52264\end{array}$ & $\begin{array}{l}-0.06(-0.35) \\
0.05958\end{array}$ & $\begin{array}{l}-0.13(-0.17) \\
0.4453\end{array}$ & $\begin{array}{c}0.32(0.15) \\
0.0318\end{array}$ \\
\hline & rs7769281 & $\begin{array}{r}-0.028(-0.17) \\
0.0 .6433\end{array}$ & $\begin{array}{l}.008(14) \\
0.014) \\
0.999\end{array}$ & $\begin{array}{l}0.044(14.14) \\
0.7763\end{array}$ & $\begin{array}{l}0.3430 .027) \\
0.0 .19899\end{array}$ & $\begin{array}{l}0.437(2) \\
0.027 \\
0.1287\end{array}$ & $\begin{array}{l}0.112(10.14) \\
0.09898)\end{array}$ & $\begin{array}{l}0.01(1.13) \\
0.9413)\end{array}$ & $\begin{array}{l}0.2010 \\
0.016) \\
0.981313\end{array}$ & $\begin{array}{c}0.010(10.13) \\
0.94323\end{array}$ & $\begin{array}{l}0.3 .3(0.25) \\
0.22822\end{array}$ & $\begin{array}{c}0.331(10.032) \\
0.343131\end{array}$ & 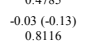 & $\begin{array}{l}-0.032(-0.13) \\
0.08685\end{array}$ & $\begin{array}{c}0.1 .09(1.13) \\
0.1854 \\
0.184\end{array}$ & $\begin{array}{c}0.10060 .14) \\
0.2168 \\
0.2168\end{array}$ & $\begin{array}{c}0.2010 .13 \\
0.1189 \\
0.189\end{array}$ & $\begin{array}{l}-0.12(-0.17) \\
0.4873\end{array}$ & 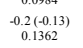 & $\begin{array}{c}-0.177(-0.13) \\
0.1912\end{array}$ & $\begin{array}{l}0.132(2.13) \\
0.375\end{array}$ & $\begin{array}{l}-0.024(-0.21) \\
0.08003\end{array}$ & 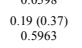 & $\begin{array}{l}0.0 .401015) \\
0.09656)\end{array}$ & $\begin{array}{l}0.01010 .13) \\
0.0 .0955 \\
0.955\end{array}$ \\
\hline & is10152719 & $\begin{array}{l}0.04(0.25) \\
0.87774\end{array}$ & $\begin{array}{l}-0.08(-0.18) \\
0.06211\end{array}$ & $\begin{array}{l}0.08(0.18) \\
0.04666\end{array}$ & $\begin{array}{l}-0.69(-0.3) \\
-0.01979\end{array}$ & $\begin{array}{l}-0.49(-0.26) \\
0.05722\end{array}$ & $\begin{array}{l}-0.23(-0.2) \\
0.2529\end{array}$ & $\begin{array}{l}0.02(0.18) \\
0.9153\end{array}$ & $\begin{array}{l}-0.04(-0.24) \\
0.8608\end{array}$ & $\begin{array}{l}0.06(0.18) \\
0.7447)\end{array}$ & $\begin{array}{l}-0.44(-0.33) \\
0.1761\end{array}$ & $\begin{array}{l}-0.25(-0.37) \\
0.00353\end{array}$ & $\begin{array}{l}-0.01(-0.17) \\
0.942323\end{array}$ & $\begin{array}{l}-0.077(-0.17) \\
0.08876\end{array}$ & $\begin{array}{l}0(0.18) \\
0.9808\end{array}$ & $\begin{array}{l}-0.05(-0.2) \\
0.78979\end{array}$ & $\begin{array}{c}-0.03(-0.19) \\
0.8802\end{array}$ & $\begin{array}{l}0.05(0.25) \\
0.84453\end{array}$ & $\begin{array}{l}0.05(0.19) \\
0.7903\end{array}$ & $\begin{array}{c}0.05(0.19) \\
0.7963\end{array}$ & $\begin{array}{l}-0.055(-0.19) \\
0.08064\end{array}$ & $\begin{array}{l}-0.04(-0.33) \\
0.89433\end{array}$ & $\begin{array}{c}0.89(0.5) \\
0.0738\end{array}$ & $\begin{array}{c}0.14(0.21) \\
0.5067\end{array}$ & $\begin{array}{l}-0.37(-0.11) \\
0.0413\end{array}$ \\
\hline & r r3341382 & $\begin{array}{c}0.18(0.18) \\
0.31477\end{array}$ & $\begin{array}{l}-0.01(-0.15) \\
0.06605\end{array}$ & $\begin{array}{c}0.24(0.15) \\
0.1174\end{array}$ & $\begin{array}{c}0.26(0.32) \\
0.4198\end{array}$ & $\begin{array}{c}0.21(0.22) \\
0.3342\end{array}$ & $\begin{array}{c}0.26(0.15) \\
0.0871\end{array}$ & $\begin{array}{c}0.23(0.15) \\
0.1214\end{array}$ & $\begin{array}{c}0.21(0.17) \\
0.2066\end{array}$ & $\begin{array}{c}0.11(0.14) \\
0.4495\end{array}$ & $\begin{array}{c}0.1(10.25) \\
0.7\end{array}$ & $\begin{array}{c}0.19(0.322) \\
0.4457\end{array}$ & $\begin{array}{c}0.03(0.14) \\
0.83533\end{array}$ & $\begin{array}{c}0.02(0.14) \\
0.99955\end{array}$ & $\begin{array}{l}-0.17(-0.15) \\
0.235\end{array}$ & $\begin{array}{l}-0.21(-0.116) \\
0.1948\end{array}$ & $\begin{array}{l}-0.16(-0.14) \\
0.2631\end{array}$ & $\begin{array}{c}0.24(0.18) \\
0.1884\end{array}$ & $\begin{array}{c}0.24(0.14) \\
0.088\end{array}$ & $\begin{array}{c}0.01(0.14) \\
0.9628\end{array}$ & $\begin{array}{l}-0.04(-0.14) \\
0.7882\end{array}$ & $\begin{array}{c}0.17(0.24) \\
0.4886\end{array}$ & $\begin{array}{l}-0.61(-0.35) \\
0.08354\end{array}$ & $\begin{array}{l}-0.18(-0.17) \\
0.29977\end{array}$ & $\begin{array}{l}0.29(0.15) \\
0.0582\end{array}$ \\
\hline & r 3341392 & $\begin{array}{c}0.15(0.24) \\
0.5282)\end{array}$ & $\begin{array}{c}0.01010 .17) \\
0.9734\end{array}$ & $\begin{array}{c}-0.15(-0.18) \\
0.3975\end{array}$ & $\begin{array}{l}-0.32(-0.37) \\
0.392828\end{array}$ & $\begin{array}{l}-0.3(-0.24) \\
0.205\end{array}$ & $\begin{array}{r}-0.38(-0.18) \\
0.0382\end{array}$ & $\begin{array}{c}-0.14(-0.17) \\
0.0098\end{array}$ & $\begin{array}{c}-0.19(-0.22) \\
0.38812\end{array}$ & $\begin{array}{r}-0.13(-0.17) \\
0.45822\end{array}$ & $\begin{array}{r}-0.3(-0.31) \\
0.3301\end{array}$ & $\begin{array}{l}-0.17(-0.4) \\
0.6643\end{array}$ & $\begin{array}{c}0.04(0.16) \\
0.79399\end{array}$ & $\begin{array}{c}0.1(0.16) \\
0.5255\end{array}$ & $\begin{array}{c}-0.16(-0.16) \\
0.3342\end{array}$ & $\begin{array}{l}-0.04(-0.118) \\
0.83858\end{array}$ & $\begin{array}{l}-0.08(-0.17) \\
0.0236\end{array}$ & $\begin{array}{c}-0.09(-0.23) \\
0.088464\end{array}$ & $\begin{array}{c}-0.02(-0.18) \\
0.92353\end{array}$ & $\begin{array}{c}0.18(0.18) \\
0.3128\end{array}$ & $\begin{array}{l}-0.11(-0.17) \\
0.5108\end{array}$ & $\begin{array}{l}-0.18(-0.31) \\
0.55411\end{array}$ & $\begin{array}{c}0.48(0.51) \\
0.3443\end{array}$ & $\begin{array}{l}0.25(0.2) \\
0.2096\end{array}$ & $\begin{array}{l}-0.46(-0.11) \\
0.0078\end{array}$ \\
\hline & $\mathrm{r} 56494229$ & $\begin{array}{c}0.04(0.17) \\
0.0051\end{array}$ & $\begin{array}{l}-0.06(-0.14) \\
0.0 .5444\end{array}$ & $\begin{array}{l}0.08(0.14) \\
0.53944\end{array}$ & $\begin{array}{l}-0.48(-0.3) \\
0.01075\end{array}$ & $\begin{array}{c}-0.27(-0.2) \\
0.1703\end{array}$ & $\begin{array}{l}-0.1(-1.1-14) \\
0.4894\end{array}$ & $\begin{array}{c}0.1(0.13) \\
0.4442\end{array}$ & $\begin{array}{l}0.0770 .16) \\
0.068989\end{array}$ & $\begin{array}{c}0.05(5.14) \\
0.7283\end{array}$ & $\begin{array}{r}-0.666(-0.25) \\
0.00999\end{array}$ & $\begin{array}{l}-0.49(-0.33) \\
0.1377\end{array}$ & $\begin{array}{c}0.01(10.13) \\
0.9527\end{array}$ & $\begin{array}{c}-0.01(-0.13) \\
0.96211\end{array}$ & $\begin{array}{r}-0.177(-0.13) \\
0.1827\end{array}$ & $\begin{array}{r}-0.17(-0.1 .14) \\
0.2333\end{array}$ & $\begin{array}{l}-0.166-(-1.13) \\
0.2026\end{array}$ & $\begin{array}{c}0.240 .177) \\
0.1631\end{array}$ & $\begin{array}{c}0.25(1.13) \\
0.0613\end{array}$ & $\begin{array}{c}0.14(1.13) \\
0.28653\end{array}$ & $\begin{array}{l}-0.13(-0.13) \\
0.34305\end{array}$ & $\begin{array}{l}0.32(2.21) \\
0.1389\end{array}$ & $\begin{array}{c}0.11(10.37) \\
0.73844\end{array}$ & $\begin{array}{l}0.055(1.16) \\
0.75858\end{array}$ & $\begin{array}{c}0.15(0.14) \\
0.2792)\end{array}$ \\
\hline & ${ }_{r 8} 88042149$ & $\begin{array}{l}0.15(1.017) \\
0.374)\end{array}$ & $\begin{array}{l}0.02(1.14) \\
0.85944\end{array}$ & $\begin{aligned}-0.04(-0.14) \\
0.74737\end{aligned}$ & $\begin{aligned}-0.41(-0.27) \\
0 \\
0.1314\end{aligned}$ & $\begin{aligned}-0.3(3-0.21) \\
0.14696\end{aligned}$ & $\begin{aligned}-0.07(-0.14) \\
0.64\end{aligned}$ & $\begin{array}{c}0.07(0.13) \\
0.6235\end{array}$ & $\begin{array}{c}0.04(10.16) \\
0.78989\end{array}$ & $\begin{aligned}-0.01(-0.14) \\
0.942\end{aligned}$ & $\begin{array}{l}-0.3(-0.02) \\
0.208\end{array}$ & $\begin{array}{l}-0.32(-1.3) \\
0.8293)\end{array}$ & $\begin{aligned}-0.08(-0.13) \\
0.53737\end{aligned}$ & $\begin{array}{c}0.05(0.13) \\
0.7012)\end{array}$ & $\begin{array}{l}-0.21(-0.13) \\
0.10 .132\end{array}$ & $\begin{aligned} 0.22(-0.15) \\
0 \\
0.1288\end{aligned}$ & $\begin{aligned}-0.19(1.0 .1 .13) \\
0.1506\end{aligned}$ & $\begin{array}{c}-0.01(-0.17) \\
0.933\end{array}$ & $\begin{array}{r}0.22(1.14) \\
0.11454\end{array}$ & $\begin{array}{r}0.32(0.14) \\
0.02033\end{array}$ & $\begin{aligned}-0.23(-0.14) \\
0.0922\end{aligned}$ & $\begin{array}{c}0.21(0.22) \\
0.3393\end{array}$ & $\begin{array}{l}0.28(0.042) \\
0.493\end{array}$ & $\begin{array}{c}0.12(2.1616 \\
0.445\end{array}$ & $\begin{array}{r}0.19(1.14) \\
0.17125)\end{array}$ \\
\hline & $\mathrm{r} 44775301$ & $\begin{array}{c}0.16(1.0 .17) \\
0.3577\end{array}$ & $\begin{array}{l}0.02(.0 .14) \\
0.9144\end{array}$ & $\begin{array}{c}0.05(0.14) \\
0.760\end{array}$ & $\begin{array}{l}-.019(-0.28) \\
0.4944\end{array}$ & $\begin{array}{c}-0.15-(-1.2) \\
0.4337\end{array}$ & $\begin{array}{l}0.02(0.15) \\
0.09098\end{array}$ & $\begin{array}{l}0.18(1.014) \\
0.1909\end{array}$ & $\begin{array}{c}0.099 .1016) \\
0.5854 .\end{array}$ & $\begin{array}{l}0.06(.0 .4) \\
0.6744)\end{array}$ & $\begin{aligned}-0.34(-0.24) \\
0.01640\end{aligned}$ & $\begin{array}{l}-0.11(-0.3) \\
0.7219\end{array}$ & $\begin{array}{l}-0.04(-0.13) \\
0.7488\end{array}$ & $\begin{array}{c}0.02(0.13) \\
0.85393\end{array}$ & $\begin{array}{c}-0.23(-0.13) \\
0.08711\end{array}$ & $\begin{array}{l}-0.29(-0.15) \\
0.0437\end{array}$ & $\begin{aligned}-0.24(-0.13) \\
0.06097\end{aligned}$ & $\begin{array}{c}0.11(1.0 .17) \\
0.44317\end{array}$ & $\begin{array}{l}0.31(.0 .14) \\
0.02714\end{array}$ & 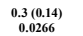 & $\begin{array}{c}-0.25(-0.14) \\
0.0707\end{array}$ & $\begin{array}{l}0.3(0.222) \\
0.11522\end{array}$ & $\begin{array}{c}0.010 .0 .98) \\
0.9784\end{array}$ & $\begin{array}{l}0.08(.016) \\
0.02399\end{array}$ & $\begin{array}{c}0.17(.14) \\
0.2341\end{array}$ \\
\hline & rs 11071561 & $\begin{array}{c}0.24(0.17) \\
0.1543\end{array}$ & $\begin{array}{c}0.05(0.14) \\
0.744\end{array}$ & $\begin{array}{c}0.08(0.14) \\
0.5525\end{array}$ & $\begin{array}{c}0.06(0.23) \\
0.7771\end{array}$ & $\begin{array}{c}0.02(0.211) \\
0.9117\end{array}$ & $\begin{array}{c}0.01(0.15) \\
0.967\end{array}$ & $\begin{array}{c}0.19(0.14) \\
0.1127\end{array}$ & $\begin{array}{c}0.18(0.16) \\
0.278\end{array}$ & $\begin{array}{c}0.03(0.14) \\
0.814\end{array}$ & $\begin{aligned}-0.14(-0.24) \\
0 \\
0.6504\end{aligned}$ & $\begin{array}{c}-0.09(-0.27) \\
0.4784\end{array}$ & $\begin{array}{c}-0.08(-0.14) \\
0.6522\end{array}$ & $\begin{array}{c}-0.04(-0.14) \\
0.767\end{array}$ & $\begin{aligned}-0.19(-0.14) \\
0.1593\end{aligned}$ & $\begin{array}{l}-0.17(-0.15) \\
0.2724\end{array}$ & $\begin{array}{c}-0.19(-0.14) \\
0.1527\end{array}$ & $\begin{array}{c}0.11(0.17) \\
0.516\end{array}$ & $\begin{array}{l}0.27(0.14) \\
0.044)\end{array}$ & $\begin{array}{c}0.3(0.14) \\
0.0285\end{array}$ & $\begin{array}{l}-0.24(-0.14) \\
0.0875\end{array}$ & $\begin{array}{l}0.41(0.23) \\
0.0078\end{array}$ & $\begin{array}{c}-0.14(-0.38) \\
0.7139\end{array}$ & $\begin{array}{c}-0.07(-0.17) \\
0.0632\end{array}$ & $\begin{array}{c}0.29(0.14) \\
0.01616\end{array}$ \\
\hline
\end{tabular}


Supplementary Table S11. Complete replication results of interaction effects between RORA and NPSR1 on asthma severity.

effect direction different to MAGICS/ISAAC

effect direction the same as in MAGICS/ISAAC

borderline significant replication

significant replication of interaction on asthma without nocturnal symptoms

\begin{tabular}{|c|c|c|c|c|}
\hline \multirow[t]{2}{*}{ NPSR1 } & \multirow[t]{2}{*}{ RORA } & $\begin{array}{l}\text { Number of doctor } \\
\text { and ED visits }\end{array}$ & \multirow{2}{*}{$\begin{array}{c}\text { Poor asthma control } \\
\text { (BAMSE) }\end{array}$} & \multirow{2}{*}{$\begin{array}{c}\begin{array}{c}\text { Number of } \\
\text { exacerbations }\end{array} \\
\text { (MAAS) }\end{array}$} \\
\hline & & (MAGICS/ISAAC) & & \\
\hline \multirow{4}{*}{ rs2609234 } & rs11635314 & $-0.83(-0.27) 0.0018$ & na & $0.26(0.2) 0.2011$ \\
\hline & rs4775289 & $0.45(0.18) \mathbf{0 . 0 1 2}$ & na & $-0.07(-0.14) 0.6233$ \\
\hline & rs4775292 & $0.43(0.18) \mathbf{0 . 0 1 5 3}$ & na & $0(-0.16) 0.9928$ \\
\hline & rs 12437690 & $-0.51(-0.18) 0.0039$ & na & $0.11(0.15) 0.4558$ \\
\hline \multirow{3}{*}{ rs714588 } & rs 4775289 & $0.4(0.14) 0.0037$ & $-0.17(-0.33) 0.6054$ & $-0.11(-0.11) 0.323$ \\
\hline & rs4775292 & $0.29(0.14) 0.0391$ & $0.47(0.37) 0.2067$ & $-0.02(-0.11) 0.8475$ \\
\hline & rs 17204454 & $0.26(0.13) \mathbf{0 . 0 4 9 7}$ & $0.43(0.36) 0.2217$ & $0.13(0.11) 0.243$ \\
\hline \multirow{3}{*}{ rs1963499 } & rs4775289 & $0.82(0.29) 0.0047$ & $-0.96(-0.63) 0.1286$ & $-0.12(-0.17) 0.48$ \\
\hline & rs17191596 & $1.86(0.59) \mathbf{0 . 0 0 1 6}$ & $-1.73(-0.8) 0.0297$ & $-0.17(-0.26) 0.5235$ \\
\hline & rs 10152719 & $-0.69(-0.3) \mathbf{0 . 0 1 9 7}$ & $1.06(0.82) 0.1929$ & $0.3(0.24) 0.2146$ \\
\hline \multirow{2}{*}{ rs2168890 } & rs4775289 & $0.63(0.21) \mathbf{0 . 0 0 2}$ & $-0.88(-0.63) 0.1617$ & $-0.07(-0.16) 0.6531$ \\
\hline & rs 17204395 & $0.48(0.24) \mathbf{0 . 0 4 8 6}$ & na & $-0.14(-0.21) 0.5102$ \\
\hline \multirow{3}{*}{ rs 2530547} & rs8024629 & $0.44(0.19) 0.0208$ & $-0.07(-0.67) 0.9138$ & $-0.09(-0.15) 0.563$ \\
\hline & rs 4775289 & $0.53(0.14) \mathbf{0 . 0 0 0 2}$ & $-0.04(-0.45) 0.9284$ & $-0.1(-0.12) 0.3726$ \\
\hline & rs341392 & $-0.38(-0.18) \mathbf{0 . 0 3 8 2}$ & $0.06(0.5) 0.8982$ & $0.06(0.14) 0.6823$ \\
\hline \multirow{4}{*}{ rs887020 } & rs 17191582 & $0.45(0.2) \mathbf{0 . 0 2 6}$ & $-0.14(-0.7) 0.8378$ & $-0.14(-0.16) 0.383$ \\
\hline & rs 8024629 & $0.55(0.18) 0.0017$ & $-0.3(-0.68) 0.6623$ & $-0.03(-0.14) 0.8144$ \\
\hline & rs17191596 & $0.51(0.22) 0.0228$ & $-0.29(-0.7) 0.6799$ & $-0.1(-0.16) 0.5126$ \\
\hline & rs4775292 & $0.36(0.14) \mathbf{0 . 0 0 9 5}$ & $0.25(0.57) 0.6614$ & $0.04(0.11) 0.7376$ \\
\hline \multirow{2}{*}{ rs1379928 } & rs 4775289 & $0.39(0.16) 0.0166$ & $-0.25(-0.44) 0.5605$ & $-0.03(-0.13) 0.7939$ \\
\hline & rs4775292 & $0.34(0.16) \mathbf{0 . 0 3 0 3}$ & $0.49(0.54) 0.3648$ & $-0.09(-0.14) 0.5139$ \\
\hline \multirow{2}{*}{ rs963218 } & rs4775289 & $0.34(0.13) 0.0122$ & $-0.15(-0.49) 0.7628$ & $-0.17(-0.1) 0.1124$ \\
\hline & rs 17237367 & $-0.35(-0.17) \mathbf{0 . 0 3 3 4}$ & $0.38(0.38) 0.3209$ & $0.05(0.13) 0.7366$ \\
\hline \multirow{4}{*}{ rs2609215 } & rs17191582 & $1.09(0.39) 0.0058$ & na & $-0.41(-0.26) 0.1165$ \\
\hline & rs8024629 & $0.83(0.35) \mathbf{0 . 0 1 8 4}$ & $-0.2(-0.92) 0.8315$ & $-0.16(-0.22) 0.4805$ \\
\hline & rs4775289 & $0.59(0.24) 0.0135$ & $-0.77(-0.46) 0.096$ & $-0.08(-0.18) 0.6824$ \\
\hline & rs17191596 & $0.94(0.41) \mathbf{0 . 0 2 0 9}$ & $-0.17(-0.94) 0.8589$ & $-0.11(-0.25) 0.6645$ \\
\hline
\end{tabular}




\begin{tabular}{|c|c|c|c|c|}
\hline & rs 17204395 & $0.78(0.31) \mathbf{0 . 0 1 2 3}$ & $0.21(1.03) 0.8344$ & $-0.06(-0.23) 0.7982$ \\
\hline & rs6494229 & $-0.66(-0.25) \mathbf{0 . 0 0 9 9}$ & $0.22(0.66) 0.7405$ & $0.1(0.2) 0.6117$ \\
\hline \multirow{2}{*}{ rs323917 } & rs 17191582 & $1.31(0.54) 0.0144$ & na & $-0.21(-0.31) 0.504$ \\
\hline & rs 17191596 & $1.43(0.58) \mathbf{0 . 0 1 3 5}$ & na & $-0.01(-0.31) 0.971$ \\
\hline rs324384 & rs 17237367 & $0.33(0.16) \mathbf{0 . 0 4 5 7}$ & $0.22(0.46) 0.6256$ & $0.01(0.13) 0.9436$ \\
\hline rs324396 & rs4775301 & $-0.29(-0.15) \mathbf{0 . 0 4 3 7}$ & $-0.57(-0.6) 0.3435$ & $-0.01(-0.12) 0.9631$ \\
\hline \multirow{2}{*}{ rs740347 } & rs4775289 & $0.5(0.18) \mathbf{0 . 0 0 6}$ & $0(-0.54) 0.9987$ & $-0.21(-0.16) 0.1822$ \\
\hline & rs 17237367 & $-0.58(-0.22) 0.0087$ & $0.77(0.43) 0.0722$ & $-0.25(-0.21) 0.235$ \\
\hline \multirow{5}{*}{ rs1419779 } & rs12899193 & $0.33(0.16) \mathbf{0 . 0 3 8 6}$ & na & $-0.03(-0.12) 0.8112$ \\
\hline & rs8024629 & $0.35(0.18) \mathbf{0 . 0 4 4 2}$ & na & $-0.1(-0.14) 0.475$ \\
\hline & rs 4775289 & $0.43(0.14) 0.0015$ & na & $-0.12(-0.11) 0.2999$ \\
\hline & rs 17237367 & $-0.46(-0.17) 0.0085$ & na & $0.02(0.15) 0.8908$ \\
\hline & rs4775301 & $0.31(0.14) \mathbf{0 . 0 2 7 1}$ & na & $-0.03(-0.12) 0.825$ \\
\hline \multirow{3}{*}{ rs324981 } & rs 8042149 & $0.32(0.14) \mathbf{0 . 0 2 0 3}$ & $0.79(0.46) 0.0884$ & $-0.03(-0.1) 0.7405$ \\
\hline & rs4775301 & $0.3(0.14) 0.0266$ & $1.01(0.43) \mathbf{0 . 0 2 0 4}$ & $-0.03(-0.11) 0.7607$ \\
\hline & rs 11071561 & $0.3(0.14) \mathbf{0 . 0 2 8 5}$ & $0.86(0.67) 0.2016$ & $0.09(0.11) 0.4195$ \\
\hline \multirow{9}{*}{ rs6972158 } & rs 17204440 & $-0.35(-0.14) 0.0126$ & na & $0(0.11) 0.9764$ \\
\hline & rs 12438866 & $-0.28(-0.14) \mathbf{0 . 0 4 9 3}$ & $0.55(0.42) 0.1939$ & $-0.11(-0.12) 0.3694$ \\
\hline & rs 17204454 & $0.28(0.14) 0.0431$ & $-0.46(-0.42) 0.2733$ & $0(0.12) 0.9978$ \\
\hline & rs 2899662 & $0.3(0.14) \mathbf{0 . 0 3 8 2}$ & $-0.28(-0.43) 0.5126$ & $0.02(0.12) 0.8742$ \\
\hline & rs 10162630 & $-0.37(-0.14) 0.0073$ & $0.04(0.37) 0.908$ & $-0.13(-0.11) 0.2604$ \\
\hline & rs7171681 & $0.32(0.15) \mathbf{0 . 0 3 1 8}$ & $-0.17(-0.49) 0.7279$ & $-0.05(-0.12) 0.682$ \\
\hline & rs 10152719 & $-0.37(-0.18) 0.0413$ & $-0.62(-0.54) 0.2561$ & $0.08(0.16) 0.621$ \\
\hline & rs341392 & $-0.46(-0.17) 0.0078$ & $-0.71(-0.46) 0.1237$ & $0.06(0.13) 0.6587$ \\
\hline & rs11071561 & $0.29(0.14) \mathbf{0 . 0 4 1 6}$ & $-0.24(-0.49) 0.6223$ & $0.06(0.12) 0.6222$ \\
\hline
\end{tabular}




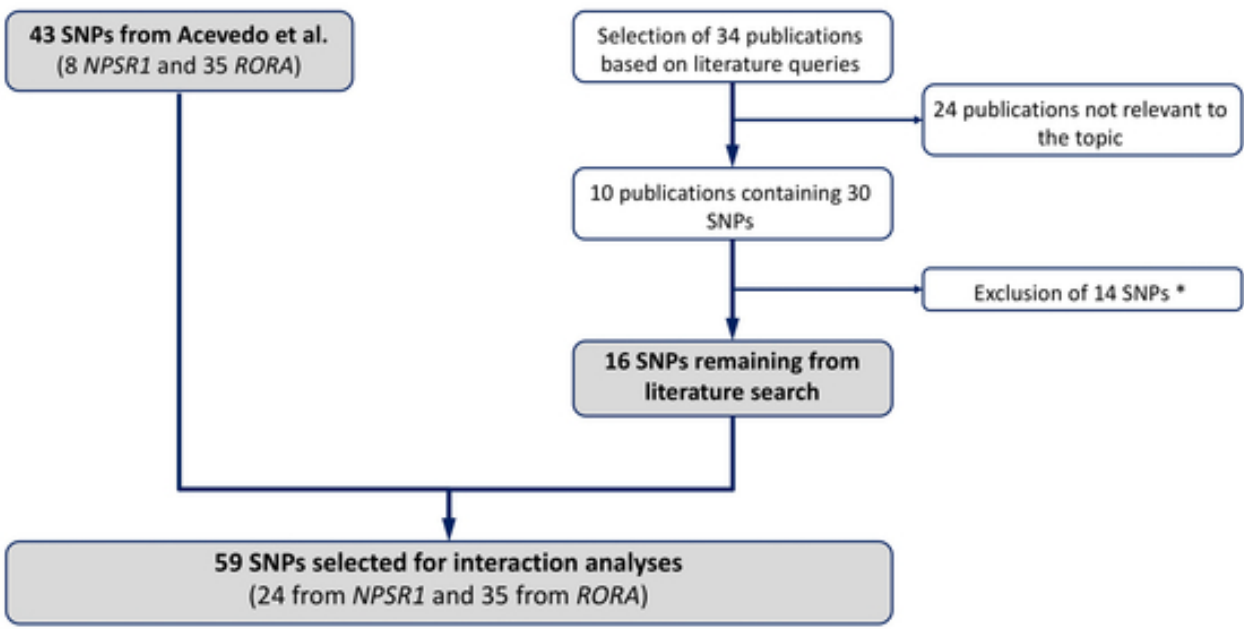

$48 \times 24 \mathrm{~mm}(300 \times 300 \mathrm{DPI})$ 


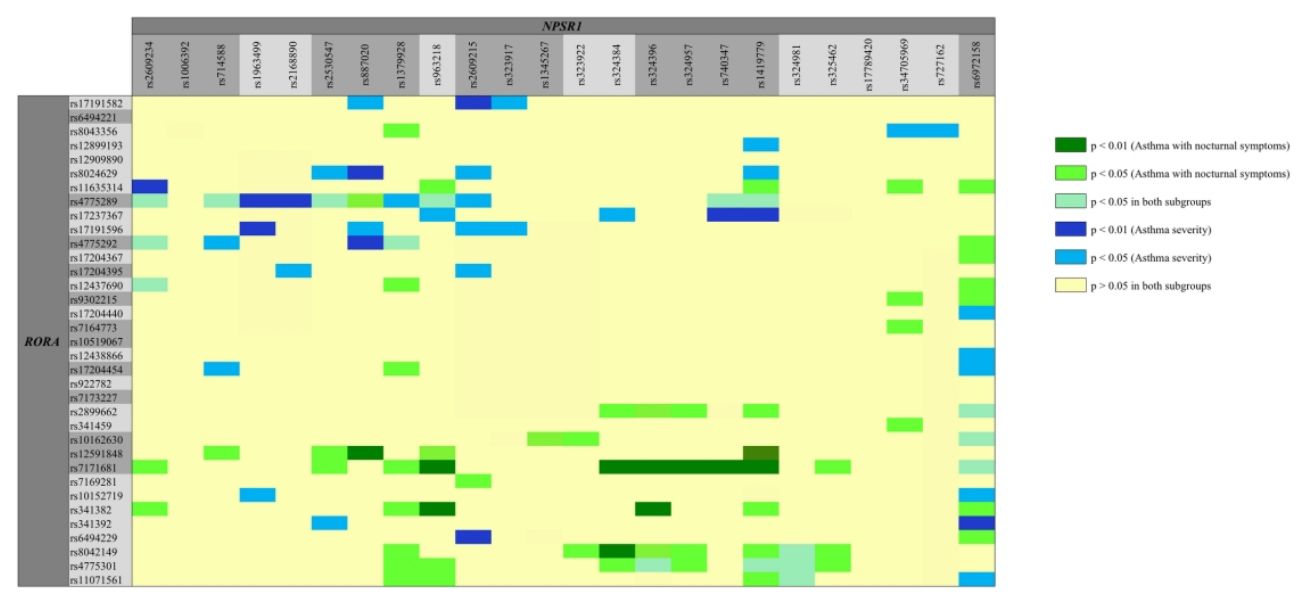

$190 \times 85 \mathrm{~mm}(300 \times 300$ DPI $)$ 


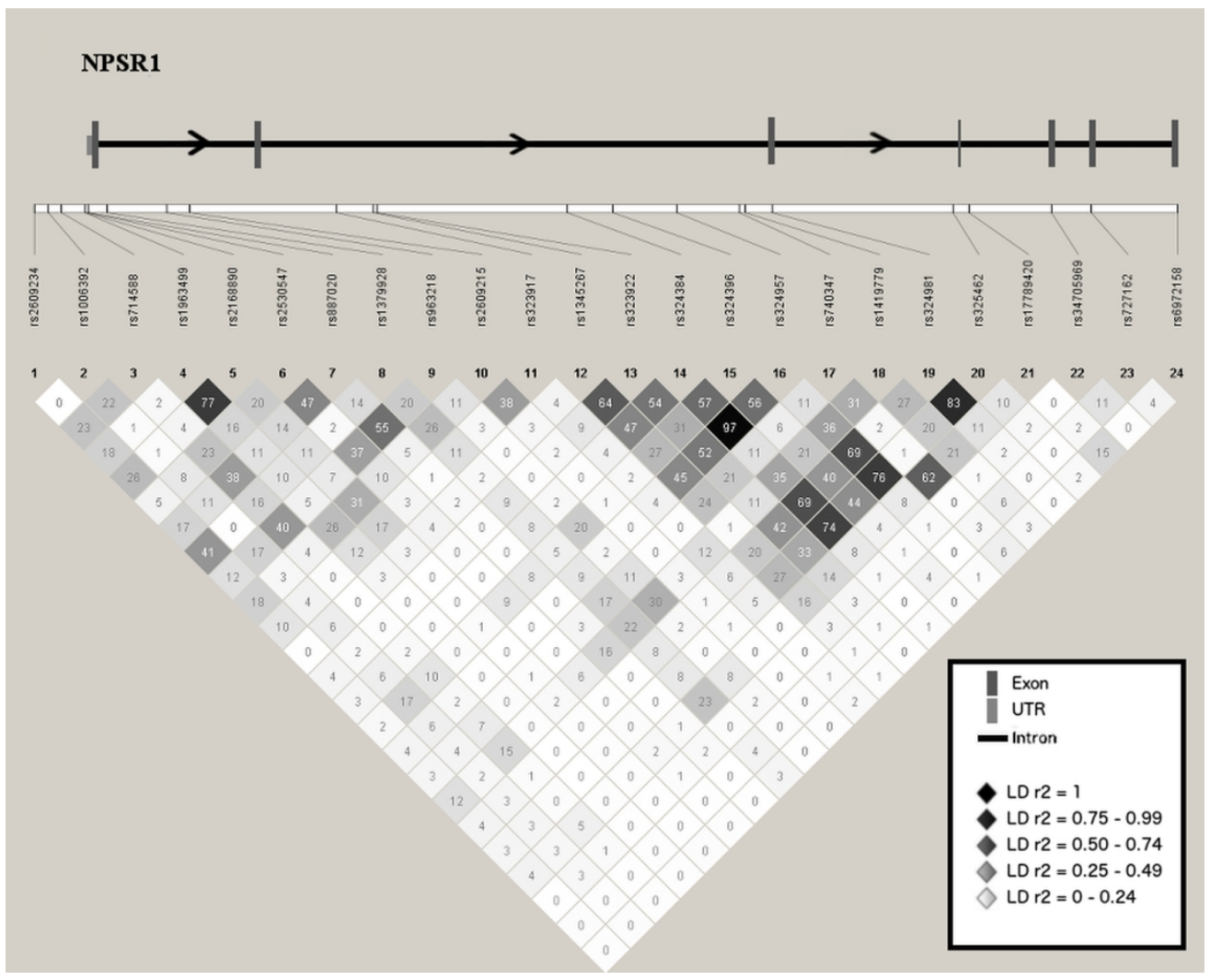

$127 \times 102 \mathrm{~mm}(300 \times 300 \mathrm{DPI})$ 


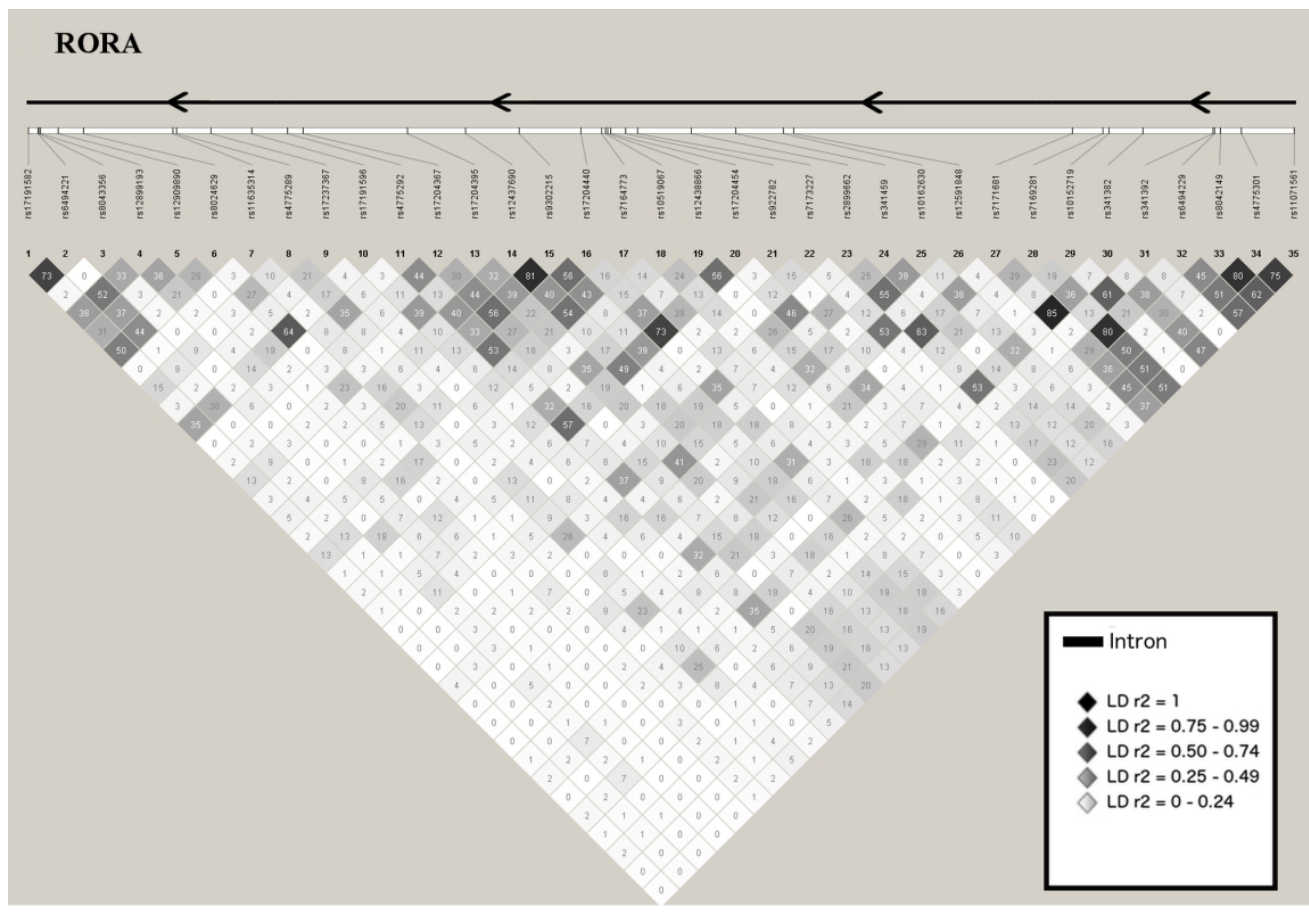

$169 \times 116 \mathrm{~mm}(300 \times 300 \mathrm{DPI})$ 


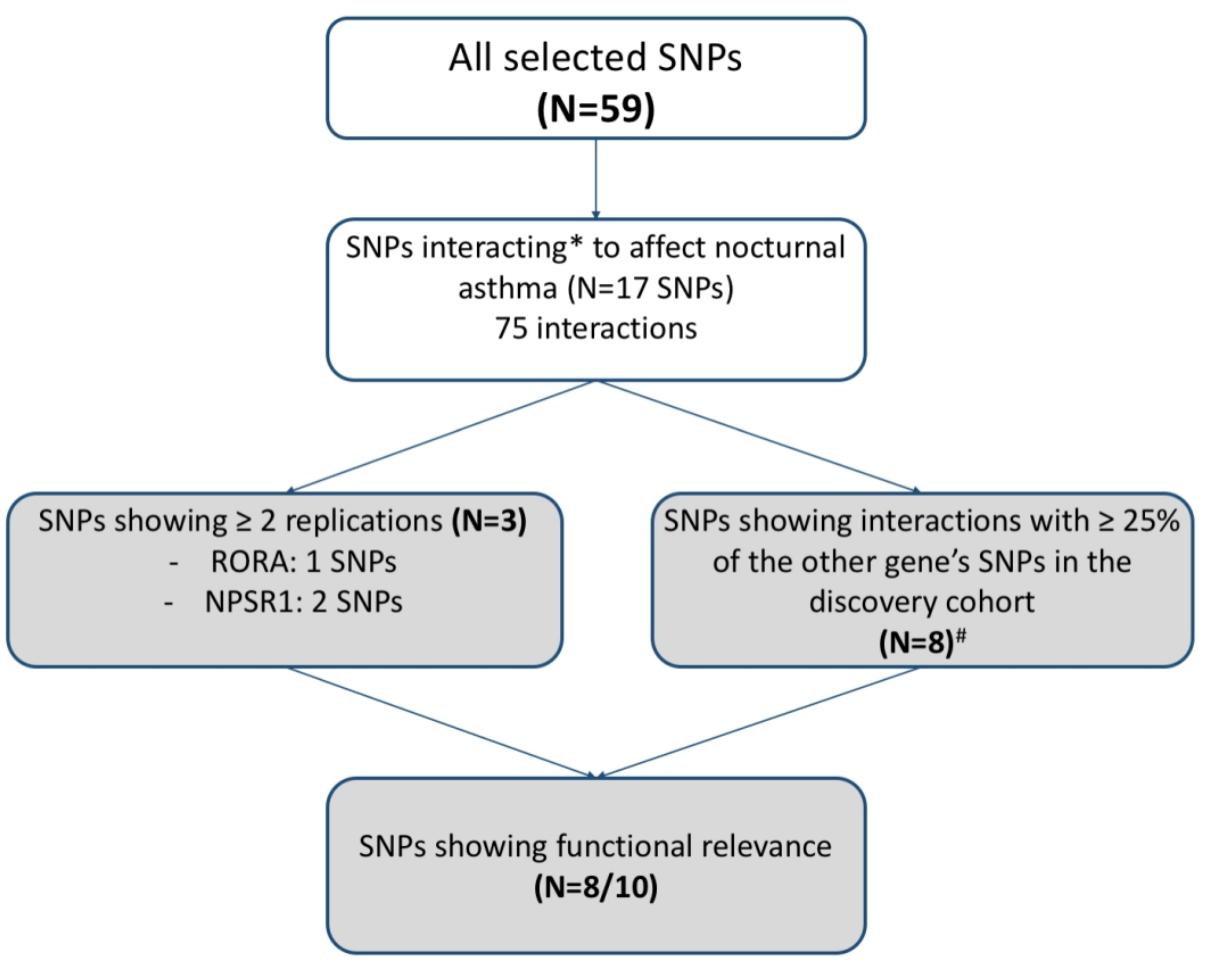

$127 \times 97 \mathrm{~mm}(300 \times 300 \mathrm{DPI})$ 